\title{
INDUÇÃO DE SUPRESSIVIDADE A Phytophthora nicotianae EM MUDAS DE LIMÃO CRAVO COM LODO DE ESGOTO
}

CAROLINA LEONI VELAZCO

Dissertação apresentada à Escola Superior de Agricultura "Luiz de Queiroz", Universidade de São Paulo, para obtenção do título de Mestre em Agronomia, Área de Concentração: Fitopatologia.

\author{
PIRACICABA \\ Estado de São Paulo, Brasil \\ Fevereiro - 2002
}




\title{
INDUÇÃO DE SUPRESSIVIDADE A Phytophthora nicotianae EM MUDAS DE LIMÃO CRAVO COM LODO DE ESGOTO
}

\author{
CAROLINA LEONI VELAZCO \\ Engenheira Agrônoma
}

Orientadora: Dra. Raquel Ghini

Dissertação apresentada à Escola Superior de Agricultura "Luiz de Queiroz", Universidade de São Paulo, para obtenção do título de Mestre em Agronomia, Área de Concentração: Fitopatologia.

\author{
PIRACICABA \\ Estado de São Paulo, Brasil \\ Fevereiro - 2002
}


Dados Internacionais de Catalogação na Publicação (CIP) DIVISÃO DE BIBLIOTECA E DOCUMENTAÇÃO - ESALQ/USP

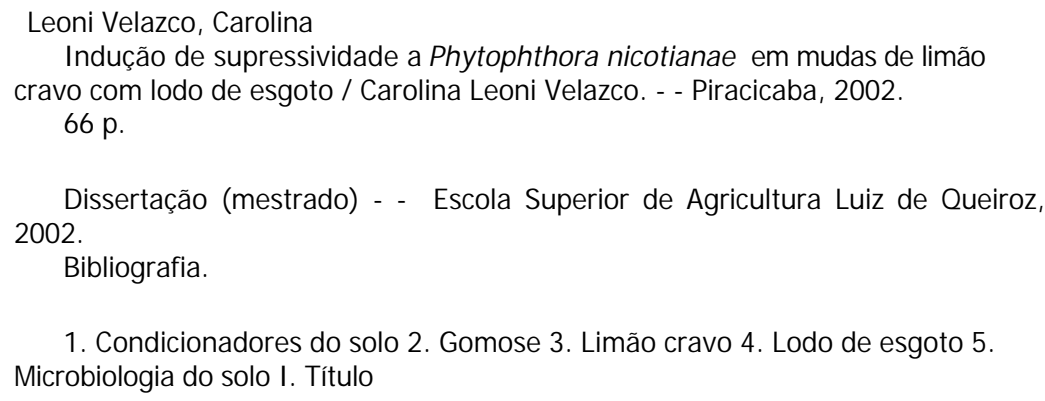

1. Condicionadores do solo 2. Gomose 3. Limão cravo 4. Lodo de esgoto 5. Microbiologia do solo I. Título

CDD 634.334

\section{"Permitida a cópia total ou parcial deste documento, desde que citada a fonte - $O$ autor"}




\section{AGRADECIMENTOS}

Ao Programa de Pós-Graduação em Fitopatologia da Escola Superior de Agricultura "Luiz de Queiroz" da Universidade de São Paulo (ESALQ - USP), pelas condições oferecidas.

À Dra. Raquel Ghini pela orientação científica e também pela confiança, amizade e estímulo.

Ao Conselho Nacional de Desenvolvimento Científico e Tecnológico (CNPq) pela bolsa de estudos concedida e à Fundação de Amparo à Pesquisa do Estado de São Paulo (FAPESP) pelo auxílio pesquisa que viabilizou este trabalho.

À Embrapa Meio Ambiente pelo oferecimento dos Laboratórios e campo experimental para a realização dos experimentos.

Aos professores e técnicos do Setor Fitopatologia da ESALQ, pelo apoio e sugestões, em especial a Sylvia pela ajuda no trabalho de laboratório. Aos secretários do Setor Fitopatologia, Jeferson e Marina, por estarem sempre dispostos a colaborar.

Aos pesquisadores da Embrapa Meio Ambiente, em especial a Wagner Bettiol pela ajuda e sugestões no trabalho.

Aos técnicos do Setor Microbiologia e ao pessoal do campo da Embrapa Meio Ambiente pela ajuda, dedicação e estímulo oferecidos durante a realização do trabalho, em especial a Mara, Rosângela, Rosely, Abrahão, Waldemore, Antônio, Brasilino, Marcelo e Nadir. 
Ao Centro de Citricultura "Sylvio Moreira" pelo fornecimento dos isolados de Phytophthora nicotianae e das sementes de limão cravo empregados nos experimentos, em especial a Carlos Aguilar Vildoso pelo estímulo e sugestões no trabalho.

À FUNDECITRUS pela doação das mudas de citros empregadas nos experimentos em casa de vegetação.

A Wilfredo Ibáñez do Sector Estadística do INIA - La Estanzuela pela ajuda nas análises estatísticas, e ao Ing. Agr. Juan P. Carnelli pela ajuda na interpretação e análise dos dados referidos àcomposição foliar e nutrição das mudas de citros.

A meus companheiros do INIA - Las Brujas, pela confiança, estímulo e apoio, em especial a Nora, Nino, José, Jorge, Diego, Guillermo, Sebastián, Wilma e Alfredo.

Ao Diretor do INIA - Las Brujas Dr. Carlos Paolino, pelo incentivo e apoio na realização do Mestrado.

A meus amigos uruguaios Ramon e Sandra pelo estímulo e apoio em todas as circunstâncias, que de alguma forma sempre estiveram aqui.

A meus pais, Carlos e Elsa, æ̀̀ minhas irmãs Lucía e Elsita, e aos meus sobrinhos Joaquín, Lucas, Valentina e Ramiro, por tudo e muito mais.

A Fernando, pelo carinho, pela amizade e dedicação, pelo apoio.

A todos os que direta ou indiretamente colaboraram para a realização deste trabalho. 


\section{SUMÁRIO}

\begin{tabular}{|c|c|c|}
\hline & & Página \\
\hline & DE TABELAS . & vii \\
\hline & DE FIGURAS & ix \\
\hline RES & & xii \\
\hline SUN & ARY ... & xiv \\
\hline 1 & INTRODUÇÃO & 1 \\
\hline 2 & 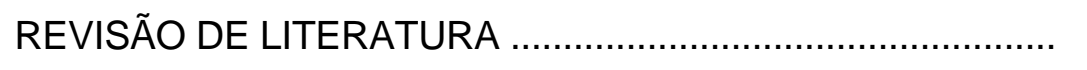 & 3 \\
\hline 2.1 & Etiologia e manejo de Phytophthora spp. em citros ................. & 3 \\
\hline 2.2 & $\begin{array}{l}\text { Matéria orgânica no controle de patógenos veiculados pelo } \\
\text { solo }\end{array}$ & 4 \\
\hline 2.3 & 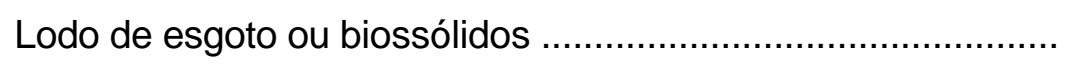 & 6 \\
\hline 2.4 & 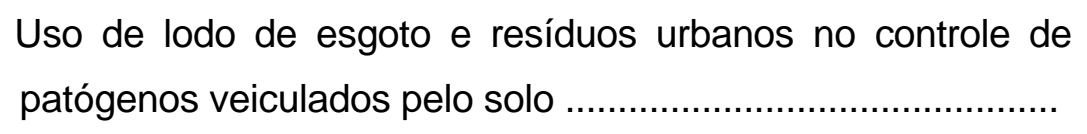 & 7 \\
\hline 3 & 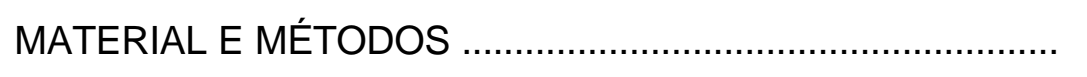 & 9 \\
\hline 3.1 & 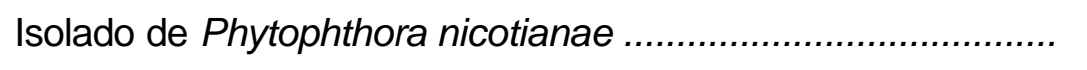 & 9 \\
\hline 3.2 & Produção de inóculo de Phytophthora nicotianae ..................... & 9 \\
\hline 3.3 & 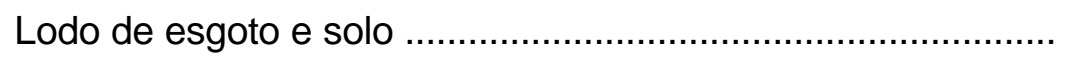 & 10 \\
\hline 3.4 & 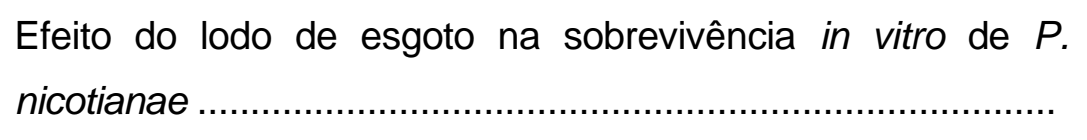 & 11 \\
\hline 3.5 & 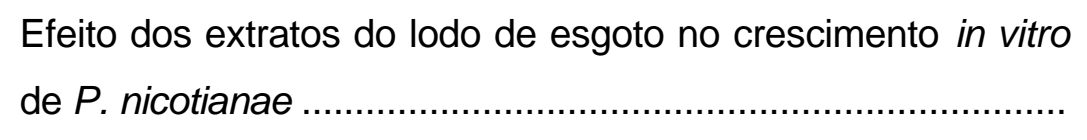 & 13 \\
\hline 3.6 & $\begin{array}{l}\text { Efeito do lodo de esgoto na indução de supressividade a } P \text {. } \\
\text { nicotianae em plântulas de limão cravo, sob telado } \ldots \ldots \ldots \ldots \ldots \ldots . . . . . . . .\end{array}$ & 14 \\
\hline 3.7 & $\begin{array}{l}\text { Efeito do lodo de esgoto na indução de supressividade a } P \text {. } \\
\text { nicotianae em mudas de limão cravo, sob telado ..................... }\end{array}$ & 15 \\
\hline
\end{tabular}




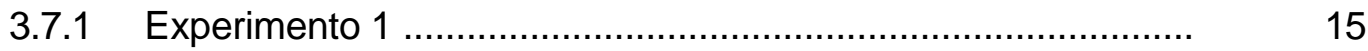

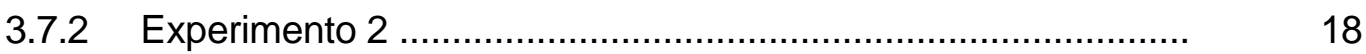

3.8 Efeito do lodo de esgoto na indução de supressividade a $P$. nicotianae em mudas de limão cravo no campo ...................... 18

3.9 Isolamento e seleção de antagonistas a P. nicotianae ............. 19

3.9.1 Isolamento de microrganismos do solo ................................... 19

3.9.2 Seleção de antagonistas: bioensaio .......................................... 20

3.9.3 Seleção de antagonistas: teste de culturas pareadas ............... 22

3.10 Análises estatísticas .............................................................

4 RESULTADOS ...............................................................

4.1 Efeito do lodo de esgoto na sobrevivência in vitro de $P$.

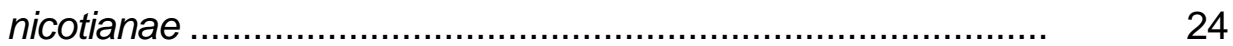

4.2 Efeito dos extratos do lodo de esgoto no crescimento in vitro de P. nicotianae ......................................................... 26

4.3 Efeito do lodo de esgoto na indução de supressividade a $P$. nicotianae em plântulas de limão cravo, sob telado .................. $\quad 27$

4.4 Efeito do lodo de esgoto na indução de supressividade a $P$. nicotianae em mudas de limão cravo, sob telado ...................... 28

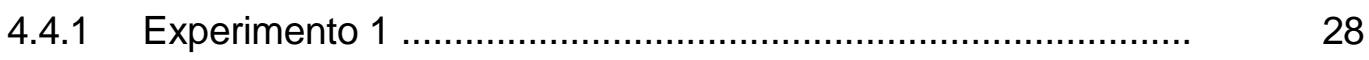

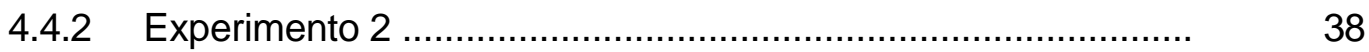

4.5 Efeito do lodo de esgoto na indução de supressividade a $P$. nicotianae em mudas de limão cravo no campo ...................... $\quad 40$

4.6 Isolamento e seleção de antagonistas a P. nicotianae .............. 46

5 DISCUSSÃO ……...........................................................

5.1 Efeito do lodo de esgoto sobre o pH e a condutividade elétrica do solo

5.2 Efeito do lodo de esgoto no desenvolvimento das plântulas e das mudas

5.3 Efeito do lodo de esgoto na indução de supressividade a $P$. nicotianae ...................................................................... 52

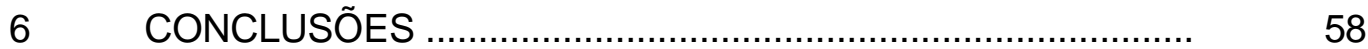

REFERÊNCIAS BIBLIOGRÁFICAS .................................................. 59 


\section{LISTA DE TABELAS}

Página

1 Análise química do lodo de esgoto empregado nos diferentes experimentos

2 Análise química da terra empregada nos diferentes experimentos .....

3 Escalas de notas empregadas no bioensaio para caracterizar o nível de infestação das plântulas de alfafa (Medicago sativa L.) crescendo na presença de Phytophthora nicotianae e dos isolados (fungos, actinomicetos, bactérias) avaliados como potenciais antagonistas .....

4 Diâmetros médios das colônias de Phytophthora nicotianae isolado IAC 01/95 aos 2, 4, 6 e 9 dias após a repicagem e área abaixo a curva de crescimento das colônias aos nove dias (AACC), crescendo em meio de cenoura (MC) contendo extratos aquosos, ácidos $\left(\mathrm{H}_{2} \mathrm{SO}_{4}\right)$ ou básicos $(\mathrm{KOH})$ de lodo de esgoto (LE) em areia ..............

5 Efeito do lodo de esgoto na composição do tecido foliar das mudas de limão cravo (Citrus lemonia) aos 150 dias após transplante, no experimento 1, em casa de vegetação

6 Efeito do lodo de esgoto na atividade microbiana do solo com $15 \mathrm{~g}$ de inóculo de Phytophthora nicotianae por vaso, avaliada pela hidrólise de diacetato de fluoresceina (FDA) e respiração microbiana $\left(\mathrm{CO}_{2}\right)$ aos 60, 90 e 150 dias após transplante (dat) das mudas de 
limão cravo (Citrus lemonia), no experimento 1

7 Correlação linear simples entre as variáveis recuperação do patógeno das raízes das mudas de limão cravo (Citrus lemonia), recuperação do patógeno do solo, hidrólise de diacetato de fluoresceina (FDA), respiração microbiana do solo $\left(\mathrm{CO}_{2}\right), \mathrm{pH}$ e condutividade elétrica (c.e.), aos 150 dias após o transplante no experimento 1

8 Efeito do lodo de esgoto na altura, peso da matéria fresca da parte aérea (pfpa) e das raízes (pfr) das mudas de limão cravo (Citrus lemonia), no pH e condutividade elétrica (c.e.) do solo - areia - lodo de esgoto, e na atividade microbiana do solo (FDA e respiração microbiana) aos 120 dias após o transplante, no experimento 2 .........

9 Efeito do lodo de esgoto na recuperação de Phytophthora nicotianae das raízes das mudas de limão cravo (Citrus lemonia) e do solo areia - lodo de esgoto, mediante o teste de iscas de folhas de citros, aos 120 dias após o transplante, no experimento 2

10 Efeito do lodo de esgoto na composição do tecido foliar das mudas de limão cravo (Citrus lemonia) aos 182 dias após o transplante, do experimento no campo

11 Efeito do inóculo e do lodo de esgoto na recuperação de Phytophthora nicotianae do solo mediante teste de isca de folhas de citros aos 82 dias após o transplante, nas parcelas do experimento no campo

12 Efeito de alguns isolados de fungos, actinomicetos e bactérias, testados quanto a potencialidade como antagonista a Phytophthora nicotianae, na infestação de plântulas de alfafa (Medicago sativa L.) . 


\section{LISTA DE FIGURAS}

Página

1 Sobrevivência de Phytophthora nicotianae avaliada por meio da porcentagem de recuperação em iscas de folhas de citros e número de zoosporângios por borda de isca, nas diferentes misturas solo lodo de esgoto, para os diferentes níveis de inóculo (0 -•-, 10 -匹- e 20 - $\Delta-\mathrm{g} \mathrm{kg}^{-1}$ de mistura), sob condições de laboratório em dois experimentos (gráficos $A$ e $B$, experimento 1; gráficos $C$ e $D$, experimento 2)

2 Efeito do lodo de esgoto no $\mathrm{pH}$ em água e na condutividade elétrica (c.e) da solução das misturas solo - lodo de esgoto, nas diferentes misturas solo - lodo de esgoto, para os diferentes níveis de inóculo

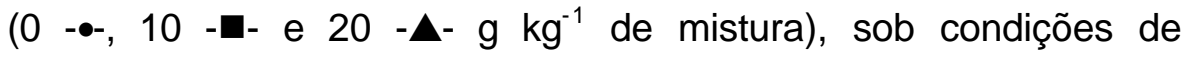
laboratório, no experimento 2

3 Efeito do lodo de esgoto na altura, peso da matéria fresca da parte aérea e peso da matéria fresca das raízes das plântulas de limão cravo (Citrus lemonia) aos 90 dias após o transplante, para os

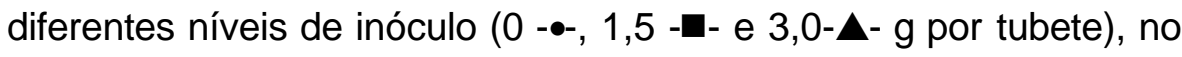
experimento 1 (gráficos $A, C, E$ ) e no experimento 2 (gráficos $B, D$, F)

4 Efeito do lodo de esgoto no $\mathrm{pH}$ em água e condutividade elétrica 
(c.e.) da solução substrato - lodo de esgoto aos 90 dias após o transplante, para os diferentes níveis de inóculo (0 -•-, 1,5 -匹- e 3,0 $\Delta$ - g por tubete), no experimento 1 (gráficos $A, C$ ) e no experimento 2 (gráficos $\mathrm{B}, \mathrm{D})$

5 Efeito do lodo de esgoto na recuperação de Phytophthora nicotianae das raízes das plântulas de limão cravo (Citrus lemonia) e das misturas substrato - lodo de esgoto, mediante o teste de iscas de folhas de citros, aos 90 dias após o transplante, para os diferentes níveis de inóculo (0 -•-, 1,5 - - e 3,0 - $\mathbf{\Delta}$ - g por tubete), no experimento 1 (gráficos $A, C$ ) e no experimento 2 (gráficos $B, D$ ) ......

6 Efeito do lodo de esgoto na altura, peso da matéria fresca da parte aérea e das raízes das mudas de limão cravo (Citrus lemonia) aos 90 (gráficos A, C, E) e 150 dias após o transplante (gráficos B, D, F),

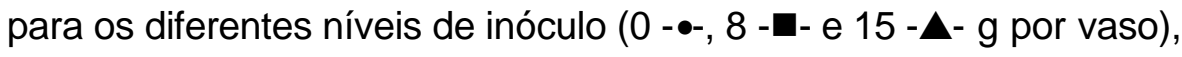
no experimento 1

7 Efeito do lodo de esgoto no $\mathrm{pH}$ em água e na condutividade elétrica (c.e.) da solução solo - lodo de esgoto aos 90 (gráficos A, C) e 150 dias após o transplante (gráficos $\mathrm{B}, \mathrm{D}$ ), para os diferentes níveis de

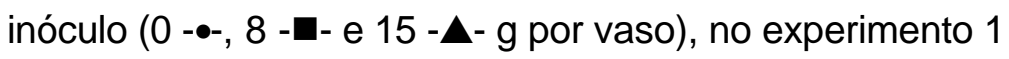

8 Efeito do lodo de esgoto na recuperação de Phytophthora nicotianae das raízes das mudas de limão cravo (Citrus lemonia), mediante o teste de iscas de folhas de citros, aos 150 dias após o transplante, para os diferentes níveis de inóculo (8 - - e 15 - $\mathbf{-}$ - g por vaso) no experimento 1

9 Evolução da altura, peso da matéria fresca da parte aérea e das raízes das mudas de limão cravo (Citrus lemonia), nos diferentes tratamentos de solo sem lodo e com adubo mineral (OA) ou com 
incorporação de lodo nas proporções de 0; 5; 7,5; 10 e $15 \%$ v/v, no experimento de campo (média dos tratamentos com e sem inóculo) .

10 Evolução da condutividade elétrica (c.e.) e pH em água da solução do solo, nos diferentes tratamentos de solo sem lodo e com adubo mineral (OA) ou com incorporação de lodo nas proporções de 0; 5; 7,$5 ; 10$ e $15 \%$ v/v, no experimento de campo (média dos tratamentos com e sem inóculo)

11 Evolução da atividade microbiana do solo avaliada pela hidrólise de diacetato de fluoresceina (FDA) e respiração microbiana (desprendimento de $\mathrm{CO}_{2}$ ), nos diferentes tratamentos de solo sem lodo e com adubo mineral (OA) ou com incorporação de lodo nas proporções de $0 ; 5 ; 7,5 ; 10$ e $15 \% \mathrm{v} / \mathrm{v}$, no experimento de campo (média dos tratamentos com e sem inóculo)

12 Comunidades de fungos, actinomicetos e bactérias (unidades formadoras de colônias - ufc) isoladas do solo do experimento do campo, com 0 ou $20 \mathrm{~g}$ de inóculo por muda de limão cravo (Citrus lemonia), aos 28 dias após o transplante, nos diferentes tratamentos de solo sem lodo e com adubo mineral (OA), ou com incorporação de lodo nas proporções de $0 ; 5 ; 7,5 ; 10$ e $15 \% \mathrm{v} / \mathrm{v}$ 


\title{
INDUÇÃO DE SUPRESSIVIDADE A Phytophthora nicotianae EM MUDAS DE LIMÃO CRAVO COM LODO DE ESGOTO
}

\author{
Autora: CAROLINA LEONI VELAZCO
}

Orientadora: Dra. RAQUEL GHINI

\section{RESUMO}

Uma alternativa de manejo das doenças de citros causadas por Phytophthora spp. é o uso de matéria orgânica. Com o objetivo de avaliar os efeitos da incorporação de lodo de esgoto ao solo na indução de supressividade a Phytophthora nicotianae Breda de Haan (1896) em plântulas de limão cravo (Citrus lemonia (L.) Osbeck), foram realizados diversos experimentos em laboratório, casa de vegetação e campo. O aumento nas doses de lodo de esgoto, nos experimentos em laboratório, em casa de vegetação e em campo, resultou na redução do $\mathrm{pH}$ e aumento da condutividade elétrica do solo; aumento da atividade microbiana do solo (avaliada pela hidrólise de diacetato de fluoresceina - FDA e pela respiração microbiana); além de uma redução na recuperação de $P$. nicotianae, tanto do substrato e do solo como das raízes de plântulas e mudas. Em alguns experimentos, a recuperação do patógeno correlacionou-se significativa e negativamente com a atividade microbiana do solo (FDA) e com a condutividade elétrica. Um melhor desenvolvimento de plântulas e mudas foi observado com a incorporação de lodo até $20 \%$. Esses resultados indicam um efeito supressivo do lodo de esgoto a $P$. nicotianae, nas condições avaliadas, explicado por fatores químicos e biológicos. Dentre os fatores químicos destacam-se o aumento da condutividade elétrica e a inibição do crescimento das colônias do patógeno em meio de cultura com extratos ácidos de lodo. Os fatores biológicos 
envolveram o aumento da atividade microbiana do solo e a presença de fungos (Aspergillus sp. e Trichoderma sp.) e actinomicetos antagonistas a $P$. nicotianae. 


\title{
SUPPRESSIVINESS INDUCTION TO Phytophthora nicotianae ON RANGPUOR LIME WITH SEWAGE SLUDGE
}

\author{
Author: CAROLINA LEONI VELAZCO
}

Adviser: Dr. RAQUEL GHINI

\section{SUMMARY}

Soil organic matter amendments may provide an alternative for the management of citrus soil diseases caused by Phytophthora spp. The effects of incorporating residential sewage sludge into the soil in order to induce suppressiviness to Phytophthora nicotianae Breda de Haan (1896) in seedlings and plantlets of rangpuor lime (Citrus limonia (L.) Osbeck) were evaluated. For this, several experiments under laboratory, greenhouse and field conditions were conducted. In almost all experiments, while sewage sludge doses enlarged, soil $\mathrm{pH}$ values decreased and soil electrical conductivity increased; soil microbial activity (evaluated by the fluorescein diacetate hydrolysis - FDA and microbial respiration) increased, and $P$. nicotianae recovery from soil and roots tended to decreased. In some experiments, significantly and negative correlations were observed between $P$. nicotianae recuperation and microbial activity (FDA), and between $P$. nicotianae recuperation and soil electrical conductivity. Seedlings and plantlets development improved at a maximum of $20 \% \mathrm{v} / \mathrm{v}$ sewage sludge soil incorporation. These results suggest a sewage sludge suppressive effect on $P$. nicotianae, explained by chemical and biological factors, under the experimental conditions of the tests performed. Among chemical factors, the increase of the soil electrical conductivity and colony growth inhibition of $P$. nicotianae on culture media amended with an acid sewage sludge extract, were indicated. The biological factors involved in suppressiviness were the 
increase of soil microbial activity and the presence of fungi (Aspergillus sp. and Trichoderma sp.) and actinomyces antagonistic to $P$. nicotianae. 


\section{INTRODUÇÃO}

Entre as doenças fúngicas que afetam os citros, o tombamento, a gomose e a podridão do pé e raízes causadas por Phytophthora spp. estão dentre as de maior importância econômica. A gomose ocorre em todas as regiões produtoras de citros e as principais espécies de Phytophthora predominantes no Brasil são $P$. nicotianae $($ sin. $=P$. parasitica) e $P$. citrophthora (Feichtenberger et al., 1997). A incidência dessas doenças aumentou após o aparecimento da tristeza e o declínio dos citros, pois a maioria dos porta-enxertos empregados é suscetível à Phytophthora (Feichtenberger, 1989; 1990).

O manejo das doenças causadas por Phytophthora inclui um conjunto de medidas preventivas e curativas, que podem variar dependendo da idade da planta e da manifestação da doença. Uma das alternativas para o manejo de patógenos de solo é o uso de diversas fontes de matéria orgânica. A matéria orgânica contribui para um controle mais efetivo dos patógenos devido ao aumento da atividade microbiana e àmelhoria das características físicas e químicas do solo (Baker \& Cook, 1974; Chung et al., 1988). Diversos estudos têm sido realizados para o manejo de Phytophthora spp. com a aplicação no solo de inúmeras fontes de matéria orgânica (Erwin \& Ribeiro, 1996).

Atualmente, uma das fontes de matéria orgânica disponível em quantidades crescentes, em diferentes regiões do país, é o lodo de esgoto proveniente das Estações de Tratamentos de Esgotos - ETE(s). Com a crescente poluição dos rios, houve necessidade de se tratar os esgotos, sendo o tratamento biológico o mais adequado. Esse tratamento resulta na produção de um lodo rico em matéria orgânica e nutrientes para as plantas, denominado lodo de esgoto ou biossólido. Esse resíduo, que necessita de uma disposição final adequada para que não cause problemas 
ambientais, constitui-se num insumo de grande valor para a agricultura, pois fornece ao solo matéria orgânica, macro e micronutrientes para as plantas, atua como condicionador de solo e fertilizante, e dessa forma, pode contribuir para a obtenção de uma agricultura mais sustentável.

De modo geral, os pomares cítricos no Brasil estão instalados em solos com baixos teores de nutrientes e matéria orgânica, baixa capacidade de troca catiônica (CTC) e de retenção de água. Assim sendo, a aplicação do lodo de esgoto como adubação orgânica pode ser altamente benéfica, face à melhoria nas propriedades do solo, incluindo aumento da disponibilidade de macro e micronutrientes, por meio da mineralização da matéria orgânica; elevação da capacidade de troca catiônica; diminuição da fixação de fósforo $(P)$ por óxidos amorfos; agregação do solo, reduzindo a suscetibilidade à erosão; aumento da capacidade de retenção de água; favorecimento das operações de preparo e das atividades microbiológicas do solo e melhoria da eficácia da adubação mineral (Magalhães, 1997). A CETESB (Companhia de Tecnologia de Saneamento Ambiental), por meio da norma P4230, normatiza a disposição de lodo de esgoto na agricultura, sendo que não existem restrições quanto àsua aplicação em citricultura (Bettiol \& Camargo, 2000).

O presente trabalho teve o objetivo de avaliar os efeitos da incorporação do lodo de esgoto ao solo na indução de supressividade a Phytophthora nicotianae Breda de Haan (1896) em plântulas e mudas de limão cravo (Citrus lemonia (L.) Osbeck), em condições de laboratório, casa de vegetação e em campo. Os efeitos da incorporação do lodo foram avaliados sobre o comportamento das plântulas e mudas (altura, peso da parte aérea e das raízes), das propriedades químicas ( $\mathrm{pH}$ e condutividade elétrica) e da atividade microbiana do solo (desprendimento de gás carbônico e hidrólise do diacetato de fluoresceina - FDA). A relação dessas variáveis com a presença de $P$. nicotianae também foi estudada. 


\section{REVISÃO DE LITERATURA}

\subsection{Etiologia e manejo de Phytophthora spp. em citros}

A gomose e a podridão do pé e das raízes causadas por Phytophthora spp. constituem uma das principais doenças fúngicas dos citros no Brasil e nas regiões produtoras de citros do mundo, causando prejuízos em viveiros e pomares. As espécies de Phytophthora reportadas causando a doença no Brasil são: $P$. citrophthora, $P$. nicotianae $(\sin .=P$. parasitica), $P$. syringae, $P$. hibernalis, $P$. palmivora, $P$. cactorum, P. cinnamomi, P. citricola, $P$. drechsleri, $P$. megasperma var. megasperma e $P$. boehmeriae. Mas, $P$. nicotianae e $P$. citrophthora são as espécies predominantes nas principais regiões produtoras no Brasil (Feichtenberger et al., 1997).

Atualmente, o manejo das doenças causadas por Phytophthora é baseado na integração de várias medidas de controle, que podem variar dependendo da idade da planta e da manifestação da doença (Erwin \& Ribeiro, 1996; Wilcox et al., 1999). As medidas preventivas nos viveiros para obtenção de mudas sadias são extremamente importantes para evitar a disseminação da doença para áreas não infestadas. O uso de porta-enxertos resistentes constitui uma das principais medidas de controle, porém, nem sempre existe boa correlação entre a resistência de uma cultivar à infecção de tronco e sua tolerância æ̀ podridões de raízes. No Brasil, a incidência dessas doenças aumentou após o aparecimento da tristeza e o declínio dos citros, pois a maioria dos porta-enxertos empregados é suscetível à Phytophthora (Feichtenberger, 1989; 1990). Também são importantes as medidas de controle da doença nos pomares, como a escolha de áreas desfavoráveis à doença, adoção de práticas de conservação de solo, uso de adubos orgânicos que favoreçam uma 
microbiota antagônica ao patógeno, manejo da irrigação e drenagem, monitoramentos freqüentes e controle químico (Erwin \& Ribeiro, 1996; Feichtenberger et al., 1997).

O controle químico pode ser muito eficiente como relatado por vários autores (Feichtenberger, 1990; Matheron \& Matejka, 1991). Porém, apesar da dificuldade de desenvolvimento de resistência de fitopatógenos do solo a fungicidas, há relatos de resistência de $P$. parasitica a metalaxyl (Ferrin \& Kabashima, 1991; Timmer et al., 1998). Esse problema, associado aos possíveis impactos no agroecossistema, tem levado àbusca de alternativas ao controle químico.

\subsection{Matéria orgânica no controle de patógenos veiculados pelo solo}

Uma das alternativas para o manejo de patógenos veiculados pelo solo é o uso de diversas fontes de matéria orgânica, tanto incorporada ao solo quanto empregada como cobertura ("mulch") e como veículo de agentes de biocontrole. A matéria orgânica contribui para um controle mais efetivo dos patógenos do solo devido ao aumento da atividade microbiana (mecanismos de antibiose, competição por nutrientes, oxigênio e/ou $\mathrm{CO}_{2}$, fungistase, hiperparasitismo, lise de hifas ou esporos, indução de resistência e outros) e àmelhoria das características físicas e químicas do solo (Baker \& Cook, 1974; Casale et al., 1995; Chung et al., 1988; Hoitink \& Boehm, 1999).

A matéria orgânica incorporada ao solo pode induzir a supressividade a determinados patógenos, entre eles Phytophthora spp. (Casale et al., 1995; Costa et al., 1996; Erwin \& Ribeiro, 1996; Hoitink \& Boehm, 1999). Segundo Baker \& Cook (1974), um solo supressivo é aquele no qual o patógeno não se estabelece ou se estabelece mas não produz a doença, ou se estabelece, produz doença por algum tempo e depois a doença torna-se pouco importante. Os processos envolvidos na supressividade do solo são complexos e incluem fatores bióticos e abióticos. 
Casale et al. (1995) sugerem que a matéria orgânica induz a supressividade a Phytophthora pela alta competição microbiana por nutrientes; pela inibição direta; pela liberação de substâncias tóxicas a Phytophthora, como dióxido de carbono, amônia, nitritos e saponinas; pela função de armadilha da matéria orgânica (zoosporos de Phytophthora são atraídos e induzidos a encistar); pela indução de resistência nas plantas; e finalmente criando um ambiente favorável ao desenvolvimento das raízes, mas não àPhytophthora sp.

Um dos exemplos mais conhecidos de controle cultural (ou integrado) de uma doença causada por Phytophthora é "The Ashburner system" na Austrália, onde as árvores de abacate crescem e produzem na presença de $P$. cinnamomi. $O$ sistema de manejo da doença baseia-se na incorporação de grandes volumes de matéria orgânica, correção do pH do solo e manutenção de uma cobertura ("mulch") que assegure uma boa quantidade de matéria orgânica na superfície do solo. Esse sistema é eficiente no controle da doença, pois mantém uma intensa atividade biológica no solo, o pH favorece o desenvolvimento de bactérias envolvidas na supressividade de $P$. cinnamomi, os altos teores de matéria orgânica e cálcio melhoram a estrutura e a drenagem do solo, o cálcio favorece a resistência do hospedeiro (plantas de abacate) e, por último, as plantas sadias têm melhor sistema radicular, extraem maiores quantidades de água e reduzem a possibilidade de saturação do solo por excessos de água Baker 1978, citado por Erwin \& Ribeiro, 1996).

Além de melhorar as propriedades físicas e químicas dos solos, o emprego de matéria orgânica no manejo de doenças causadas por espécies de Phytophthora baseia-se na baixa capacidade saprofítica e competitiva do patógeno em relação a outros microrganismos no solo. A partir de estudos em solos supressivos a Phytophthora, diversos microrganismos têm sido reportados como parcialmente responsáveis por tal propriedade. Entre eles, vale citar fungos dos gêneros Trichoderma, Gliocladium, Myrothecium e Penicillium; bactérias dos gêneros Bacillus, Enterobacter e Pseudomonas; e actinomicetos do gênero Streptomyces (Erwin \& Ribeiro, 1996). 


\title{
2.3 Lodo de esgoto ou biossólidos
}

\begin{abstract}
Como conseqüência do crescimento populacional e das regulamentações internacionais sobre disposição final de resíduos visando uma melhoria das condições ambientais do planeta, atualmente, uma das fontes de matéria orgânica disponível em quantidades crescentes no mundo são os biossólidos ou lodos de esgoto provenientes das Estações de Tratamentos de Esgotos - ETE(s) e os resíduos urbanos sólidos compostados (Andreoli \& Pegorini, 2000; Casale et al., 1995; Hoitink \& Boehm, 1999)
\end{abstract}

O lodo de esgoto é o resíduo gerado no tratamento dos esgotos com a finalidade de reduzir a sua carga poluidora para garantir seu retorno ao ambiente diminuindo a degradação ambiental. Existem diversas alternativas para o tratamento dos esgotos, entre elas o tratamento biológico que consiste na redução da carga orgânica desse efluente por meio da atividade dos microrganismos que oxidam parte da matéria orgânica e formam flocos biológicos que podem ser separados do esgoto por decantação (Andreoli \& Pegorini, 2000).

O lodo de esgoto necessita de uma disposição final que não cause problemas ambientais. A forma de disposição final vai depender de sua carga poluidora (conteúdo de metais pesados e patógenos humanos, entre outros) e das possibilidades locais. O uso agrícola do lodo de esgoto, como alternativa de disposição final, está sendo pesquisado no mundo e regulamentações internacionais foram definidas visando àproteção a saúde humana e animal, além da qualidade das colheitas, do solo e do ambiente em todo o mundo. O lodo de esgoto constitui um insumo de grande valor para a agricultura, pois fornece ao solo matéria orgânica, macro e micronutrientes para as plantas, atua como condicionador de solo e incrementa a comunidade de organismos do solo (Andreoli \& Pegorini, 2000). Embora a maioria das pesquisas tenha sido feita na área da fertilidade e recuperação de solos degradados, alguns trabalhos avaliam o efeito nas comunidades microbianas e em patógenos do solo. 


\subsection{Uso de lodo de esgoto e resíduos urbanos no controle de patógenos veiculados pelo solo}

Lumsden et al. (1983) estudaram o efeito dos biossólidos no controle de diversos patógenos veiculados pelo solo sob condições de casa de vegetação. Eles avaliaram doses (0,10, 20 e 30\% v/v, em base seca) e épocas de incorporação do biossólido ao solo visando ao controle de diversos fitopatógenos em várias culturas. Os autores observaram que a adição de $10 \%(\mathrm{v} / \mathrm{v})$ de biossólido teve um efeito variável dependendo do patossistema avaliado: aumento, diminuição ou sem efeito no desenvolvimento da doença. Verificaram redução na incidência de podridões de raízes causadas por Aphanomyces solani em ervilhas, por Rhizoctonia solani em feijão e algodão; do tombamento causado por $R$. solani em rabanete e por Pythium myorityum em feijão; e por Sclerotinia minor em alface; e da murcha causada por Fusarium oxysporum f.sp. melonis em melão e a podridão da coroa em pimenta causada por Phytophthora capsici. Observaram ainda que o lodo não apresentou efeito sobre as podridões de raízes causadas por Thielaviopsis basicola em feijão cv. Blue Lake e algodão, e no tombamento causado por Pythium aphanidermatum em feijão. $O$ incremento na incidência da doença foi verificado nos patossistemas Pythium ultimum - ervilha, Fusarium solani f.sp. pisi - ervilha e Thielaviopsis basicola - feijão cv. Tendercrop.

Millner et al. (1981) estudaram o efeito do lodo de esgoto incorporado ao solo em parcelas no campo para diferentes patossistemas. No caso da alface tombamento ( $S$. minor), nos três anos avaliados, a incidência da doença foi menor nos tratamentos com lodo, embora os níveis de propágulos se mantivessem semelhantes. No segundo patossistema, ervilhas - tombamento (Pythium sp. e $R$. solani), os efeitos do lodo de esgoto no controle da doença foram observados no segundo e terceiro anos. No terceiro patossistema avaliado, algodão - tombamento, os tratamentos com lodo não controlaram a doença em nenhum dos anos avaliados. Esses resultados estariam indicando uma forte interação da cultura (ervilha, algodão) com os patógenos (Pythium sp. e R. solani). 
Lewis et al. (1992) reportaram uma redução na incidência de tombamento causado por $R$. solani e $P$. ultimum em ervilhas e em algodão, cultivados no campo em solo previamente tratado com 7 a $10 \mathrm{t} \mathrm{ha}^{-1}$ de lodo de esgoto, sendo o efeito atribuído à indução de supressividade do solo aos patógenos. Embora a incidência de tombamento em plântulas de ervilha tenha diminuído após a aplicação do lodo de esgoto, o mesmo não ocorreu com a densidade de inóculo de $P$. ultimum.

No Brasil, Bettiol \& Krügner (1984) verificaram que o lodo de esgoto, especialmente em altas concentrações, reduziu a severidade da podridão de raízes de plantas de sorgo, causada por $P$. arrhenomanes, além de estimular o crescimento das plantas, tanto na ausência, como na presença do patógeno. Schoenmaker \& Ghini (1999) obtiveram melhores resultados no controle de Pythium spp. com cama-defrango do que com lodo de esgoto, provavelmente devido àconcentração aplicada.

Kim et al. (1997), avaliando os efeitos de diferentes fontes de matéria orgânica no controle de $P$. capsici em pimentão em experimentos no campo, observaram que os tratamentos nos quais o lodo de esgoto compostado com resíduo de jardinagem foi empregado, a incidência e severidade da doença foram semelhantes ஷ̀ obtidas com as outras fontes de matéria orgânica avaliadas, embora os níveis de doença fossem altos em todos os tratamentos e nem sempre diferenciaram-se da testemunha.

Widmer et al. (1998) encontraram que composto de lixo urbano aplicado a solos arenosos aumentou a supressividade a $P$. parasitica em testes realizados com citros cultivados em casa de vegetação. Houve efeito fitotóxico devido ao teor de sais solúveis e ácido acético do composto, na concentração de $20 \%(\mathrm{v} / \mathrm{v})$, porém a incidência da doença foi reduzida, em alguns casos, de $95 \%$ a $5 \%$. O composto fresco reduziu o diâmetro das colônias do patógeno, sendo que após períodos de armazenamento, não houve a redução. Os mecanismos de ação do material no controle do patógeno foram atribuídos æ̀̀ espécies de Acremonium antagônicas a $P$. parasitica isoladas e também aos altos teores de ácido acético. 


\section{MATERIAL E MÉTODOS}

\subsection{Isolado de Phytophthora nicotianae}

O isolado IAC 01/95 de Phytophthora nicotianae Breda de Haan (1896) (sin. P. parasitica Dastur (1913)) empregado nos experimentos foi fornecido pelo Centro de Citricultura Sylvio Moreira - Instituto Agronômico de Campinas (CCSM IAC). $O$ isolado foi mantido em água destilada esterilizada em temperatura ambiente e ausência de luz.

\subsection{Produção de inóculo de Phytophthora nicotianae}

O inóculo foi produzido em grãos de trigo autoclavados em sacos de polipropileno acrescidos com o patógeno, segundo o método de McGovern et al. (2000) modificado.

No primeiro dia, sacos de polipropileno de $30 \times 40 \mathrm{~cm}$ com $350 \mathrm{~g}$ de grãos de trigo e $200 \mathrm{~mL}$ de água destilada foram autoclavados a $121^{\circ} \mathrm{C}$, por 40 minutos. No segundo dia, foram acrescentados aos sacos mais $150 \mathrm{~mL}$ de água destilada e, a seguir, foram fechados hermeticamente com auxílio de uma seladora e autoclavados por mais 20 minutos a $121^{\circ} \mathrm{C}$. No terceiro dia, sob condições de assepsia, cada saco recebeu 40 discos de $5 \mathrm{~mm}$ de diâmetro de meio de cultura contendo micélio do patógeno, das bordas de uma colônia com 7 dias de idade, crescendo em meio de cenoura ( $50 \mathrm{~g}$ cenoura cozida e triturada no liquificador; $10 \mathrm{~g}$ de dextrose; $16 \mathrm{~g}$ de ágar; água destilada até completar $1 \mathrm{~L})$. Finalmente, os sacos foram incubados por quatro ou cinco semanas, em temperatura ambiente (aproximadamente 
$25^{\circ} \mathrm{C}$ ), sendo feitas agitações quando necessárias para homogeneizar a colonização dos grãos.

\subsection{Lodo de esgoto e solo}

O lodo de esgoto empregado foi obtido da Estação de Tratamento de Esgoto (ETE) de Franca, SP. Esse lodo é de origem residencial, com baixos teores de metais pesados (Tabela 1).

Tabela 1. Análise química do lodo de esgoto empregado nos diferentes experimentos.

\begin{tabular}{lc}
\hline Atributo & \\
\hline pH em água & \\
$\%$ Umidade $\left(65{ }^{\circ} \mathrm{C}\right)$ & 6,4 \\
$\mathrm{C}\left(\mathrm{g} \mathrm{kg}^{-1}\right)$ & 83,3 \\
$\mathrm{~N} \mathrm{Kjeldal}\left(\mathrm{g} \mathrm{kg}^{-1}\right)$ & 374,4 \\
$\mathrm{~N}-$ amoniacal $\left(\mu \mathrm{g} \mathrm{g}^{-1}\right)$ & 50,8 \\
$\mathrm{~N}$-Nitrato-Nitrito $\left(\mu \mathrm{g} \mathrm{g}^{-1}\right)$ & 119,5 \\
$\mathrm{P}\left(\mathrm{g} \mathrm{kg}^{-1}\right)$ & 54,8 \\
$\mathrm{~K}\left(\mathrm{~g} \mathrm{~kg}^{-1}\right)$ & 21,3 \\
$\mathrm{Ca}\left(\mathrm{g} \mathrm{kg}^{-1}\right)$ & 0,99 \\
$\mathrm{Mg}\left(\mathrm{g} \mathrm{kg}^{-1}\right)$ & 16,8 \\
$\mathrm{~S}\left(\mathrm{~g} \mathrm{~kg}^{-1}\right)$ & 2,5 \\
$\mathrm{Mo}\left(\mathrm{mg} \mathrm{kg}^{-1}\right)$ & 13,3 \\
$\mathrm{~B}\left(\mathrm{mg} \mathrm{kg}^{-1}\right)$ & $<1$ \\
$\mathrm{Na}\left(\mathrm{g} \mathrm{kg}^{-1}\right)$ & 7,1 \\
$\mathrm{Cr}\left(\mathrm{mg} \mathrm{kg}^{-1}\right)$ & 0,6 \\
$\mathrm{Mn}\left(\mathrm{mg} \mathrm{kg}^{-1}\right)$ & 1325 \\
$\mathrm{Fe}\left(\mathrm{mg} \mathrm{kg}^{-1}\right)$ & 267,4 \\
$\mathrm{Ni}\left(\mathrm{mg} \mathrm{kg}^{-1}\right)$ & 31706 \\
$\mathrm{Cu}\left(\mathrm{mg} \mathrm{kg}^{-1}\right)$ & 74,7 \\
$\mathrm{Zn}\left(\mathrm{mg} \mathrm{kg}^{-1}\right)$ & 359,2 \\
$\mathrm{Al}\left(\mathrm{mg} \mathrm{kg}^{-1}\right)$ & 1590 \\
$\mathrm{Cd}\left(\mathrm{mg} \mathrm{kg}^{-1}\right)$ & 33550 \\
$\mathrm{~Pb}\left(\mathrm{mg} \mathrm{kg}^{-1}\right)$ & 2 \\
$\mathrm{Ar}\left(\mathrm{mg} \mathrm{kg}^{-1}\right)$ & 118,8 \\
$\mathrm{Se}\left(\mathrm{mg} \mathrm{kg}^{-1}\right)$ & $<1$ \\
$\mathrm{Hg}\left(\mathrm{mg} \mathrm{kg}^{-1}\right)$ & 0 \\
& $<1$ \\
\hline
\end{tabular}


O Latossolo vermelho - amarelo fase argilosa, utilizado nos diferentes experimentos no laboratório e casa de vegetação, foi obtido no campo experimental da Embrapa Meio Ambiente (Jaguariúna, SP), no local onde também foi instalado o experimento de campo (Tabela 2).

Tabela 2. Análise química da terra empregada nos diferentes experimentos.

\begin{tabular}{lc}
\hline Atributo & \\
\hline $\mathrm{pH}(\mathrm{em} \mathrm{CaCl})$ & 5,1 \\
Matéria orgânica $\left(\mathrm{g} \mathrm{dm}^{-3}\right)$ & 25 \\
$\mathrm{P}\left(\mathrm{mg} \mathrm{dm}^{-3}\right)$ & 14 \\
$\mathrm{~K}\left(\mathrm{mmol} \mathrm{dm}^{-3}\right)$ & 2,6 \\
$\mathrm{Ca}\left(\mathrm{mmol} \mathrm{dm}^{-3}\right)$ & 19 \\
$\mathrm{Mg}\left(\mathrm{mmol} \mathrm{dm}^{-3}\right)$ & 11 \\
$\mathrm{Soma} \mathrm{de} \mathrm{bases}\left(\mathrm{mmol} \mathrm{dm}^{-3}\right)$ & 32,6 \\
$\mathrm{H}+\mathrm{Al}\left(\mathrm{mmol} \mathrm{dm}^{-3}\right)$ & 28 \\
$\mathrm{CTC}\left(\mathrm{mmol} \mathrm{dm}^{-3}\right)$ & 60,4 \\
$\mathrm{~V}(\%)$ & 54 \\
$\mathrm{Fe}\left(\mathrm{mg} \mathrm{kg}^{-1}\right)$ & 31 \\
$\mathrm{Mn}\left(\mathrm{mg} \mathrm{kg}^{-1}\right)$ & 10,4 \\
$\mathrm{Cu}\left(\mathrm{mg} \mathrm{kg}^{-1}\right)$ & 0,8 \\
$\mathrm{Zn}\left(\mathrm{mg} \mathrm{kg}^{-1}\right)$ & 3,3 \\
$\mathrm{~B}\left(\mathrm{mg} \mathrm{kg}^{-1}\right)$ & 0,19 \\
& \\
\hline
\end{tabular}

\subsection{Efeito do lodo de esgoto na sobrevivência in vitro de $P$. nicotianae}

O lodo de esgoto foi misturado ao solo úmido previamente desinfestado em forno de microondas de $900 \mathrm{~W}$ de potência (600 g de solo por 6 minutos), nas proporções de 0, 10, 20 e 40\% p/p. Cada uma das misturas de solo - lodo de esgoto recebeu o equivalente a 0,10 ou $20 \mathrm{~g}$ de inóculo de Phytophthora $\mathrm{kg}^{-1}$. As misturas foram colocadas em sacos plásticos de $30 \times 40 \mathrm{~cm}$ e $100 \mu \mathrm{m}$ de espessura, fechados (mas não hermeticamente) e mantidos a $27^{\circ} \mathrm{C} \pm 2$. Após 21 dias, os sacos foram abertos e a sobrevivência de $P$. nicotianae foi avaliada mediante $o$ teste de iscas de folhas de citros, determinando-se a recuperação do patógeno (porcentagem de iscas com zoosporângios nas bordas) e o número de zoosporângios formados nas bordas 
das iscas. A condutividade elétrica e o pH das misturas foram também determinados. $O$ experimento foi repetido duas vezes.

O teste de isca de folhas de citros utilizado foi modificado a partir de Grimm \& Alexander (1973). Em placas de Petri plásticas de $9 \mathrm{~cm}$ de diâmetro, previamente desinfestadas com álcool $70^{\circ}$, foram colocados $5 \mathrm{~g}$ da mistura solo - lodo de esgoto, $30 \mathrm{~mL}$ de água destilada e 20 fragmentos de folhas de citros de $3 \times 3 \mathrm{~mm}$. As placas foram mantidas a $27^{\circ} \mathrm{C} \pm 2$ e luz fluorescente continua por $48 \mathrm{~h}$, quando realizou-se a avaliação das iscas. Para avaliação, as iscas foram transferidas para lâminas com água e cobertas com lamínula, e observadas no microscópio óptico com um aumento de 100 vezes. As folhas de citros empregadas no teste foram obtidas de plantas de laranja que não tinham recebido nenhum tratamento químico, e foram desinfestadas com álcool $70^{\circ}$ por 1 minuto.

Para determinar o $\mathrm{pH}$ e a condutividade elétrica, num Erlenmeyer de 100 $\mathrm{mL}$ de capacidade foram colocados $10 \mathrm{~g}$ da mistura solo - lodo de esgoto e $25 \mathrm{~mL}$ de água destilada deionizada. Foi realizada agitação a $120 \mathrm{rpm}$ por 15 minutos. Após deixar em repouso por 30 minutos, procedeu-se a leitura do $\mathrm{pH}$ e da condutividade elétrica do sobrenadante. Para cada repetição foram feitas duas réplicas e três leituras de cada.

Os tratamentos se constituíram da combinação dos fatores doses de lodo $\left(0,10,20\right.$ e 40\%) e níveis de inóculo $\left(0,10\right.$ ou $\left.20 \mathrm{~g} \mathrm{~kg}^{-1}\right)$, com cinco repetições. Para a análise estatística, os dados de recuperação do patógeno (porcentagem de iscas com zoosporângios nas bordas) foram transformados em arco seno $\sqrt{ } x / 100$. As correlações entre as variáveis recuperação do patógeno, condutividade elétrica e pH foram estabelecidas. 


\subsection{Efeito dos extratos do lodo de esgoto no crescimento in vitro de $P$. nicotianae}

Os extratos foram obtidos segundo o método de Widmer et al. (1998) modificado. Misturas de $100 \mathrm{~g}$ de areia (lavada, esterilizada e seca) e $20 \mathrm{~g}$ de lodo de esgoto (proporção de 16,6 \% p/p), com $100 \mathrm{~mL}$ da solução de $\mathrm{H}_{2} \mathrm{SO}_{4} 2 \mathrm{~N}(57,7 \mathrm{~mL}$ de $\mathrm{H}_{2} \mathrm{SO}_{4}$ para análise (p.a.) em $1000 \mathrm{~mL}$ de água destilada), $\mathrm{KOH} \mathrm{0,4} \mathrm{N} \mathrm{(22,4} \mathrm{g} \mathrm{KOH} \mathrm{p.a.}$ em $1000 \mathrm{~mL}$ de água destilada) ou água bidestilada esterilizada. Como testemunha foi empregada areia $(120 \mathrm{~g})$ com $100 \mathrm{~mL}$ de cada uma das soluções. Os Erlenmeyers de $250 \mathrm{~mL}$ de capacidade contendo as misturas areia - lodo com as soluções foram agitados manualmente, e a seguir, deixou-se àtemperatura ambiente por 6 hs. Ao final desse período, filtraram-se as misturas em algodão, seguido de filtragem a vácuo com papel de filtro Whatman 41 e membrana Millipore $0,22 \mu \mathrm{m}$ de porosidade. $\mathrm{O} \mathrm{pH}$ de cada um dos extratos obtidos foi ajustado para valores entre 5,5-6,0 com soluções de $\mathrm{KOH} 10 \mathrm{~N}$ (112 g KOH p.a. em $200 \mathrm{~mL}$ de água destilada) ou $\mathrm{H}_{2} \mathrm{SO}_{4} 12 \mathrm{M} \mathrm{(138,5} \mathrm{mL}$ $\mathrm{H}_{2} \mathrm{SO}_{4}$ p.a. em $200 \mathrm{~mL}$ de água destilada), previamente autoclavadas por 20 minutos a $121^{\circ} \mathrm{C}$. Finalmente, preparou-se meio de cultura contendo os diferentes extratos na proporção 9:1 (225 mL de meio de cultura de cenoura e $25 \mathrm{~mL}$ de extrato), $50 \mathrm{mg} \mathrm{L}^{-1}$ de rifampicina e $50 \mathrm{mg} \mathrm{L}^{-1}$ de ampicilina, e $15 \mathrm{~mL}$ do meio foram vertidos em placas de Petri de $9 \mathrm{~cm}$ de diâmetro. Discos de $5 \mathrm{~mm}$ de diâmetro de meio de cultura contendo micélio do patógeno, com 7 dias de idade foram transferidos para as placas que foram mantidas a $27^{\circ} \mathrm{C} \pm 2$ e luz fluorescente contínua. Como testemunha foram utilizadas placas contendo meio de cultura com antibióticos e sem extratos. $O$ efeito dos extratos foi avaliado medindo-se dois diâmetros perpendiculares das colônias, a cada dois dias. Após nove dias de incubação, a área abaixo a curva do crescimento da colônias (AACC) foi calculada.

O delineamento experimental foi de parcelas inteiramente casualizadas, com oito repetições. 


\title{
3.6 Efeito do lodo de esgoto na indução de supressividade a $P$. nicotianae em plântulas de limão cravo, sob telado.
}

\begin{abstract}
Sementes pré-germinadas de limão cravo (Citrus lemonia) foram semeadas em substrato comercial (Plantmax $®$ ) tratado com lodo de esgoto nas proporções de $0,5,10,15,20$ e 30\% volume/volume ( $v / v)$ e infestado com $0 ; 1,5$ ou $3 \mathrm{~g}$ de inóculo por tubete de $45 \mathrm{~mL}$ de capacidade. $O$ inóculo foi produzido em grãos de trigo (item 3.2). As plântulas foram mantidas sob condições de telado e irrigadas regularmente. No terceiro mês, foram determinados o peso da matéria fresca da parte aérea das plântulas, o comprimento (só no experimento 1) e o peso da matéria fresca das raízes, a altura das plântulas, a presença do patógeno no substrato e nas raízes mediante o teste de iscas de folhas de citros (avaliados por meio da porcentagem de recuperação, como já descrito), e o pH e a condutividade elétrica das diferentes misturas de substrato - lodo de esgoto. Durante o experimento, as plântulas mortas foram avaliadas quanto à recuperação ou não de $P$. nicotianae mediante o teste de folhas de citros em raízes (sistema radicular completo em uma placa) e substrato ( $5 \mathrm{~g}$ por placa, duas placas por tubete).
\end{abstract}

No primeiro experimento, além do tratamento sem lodo, foi utilizado como testemunha um tratamento sem lodo e com adubação mineral semanal (adubo foliar completo, Agifol; $2,5 \mathrm{~mL} \mathrm{~L}^{-1}$ ).

A germinação das sementes de limão cravo no primeiro experimento foi feita em papel de germinação umedecido, em caixas plásticas fechadas e mantidas a temperatura ambiente (aproximadamente $27^{\circ} \mathrm{C}$ ). No segundo experimento, a germinação das sementes foi feita em vermiculita e as bandejas foram mantidas em casa de vegetação e irrigadas regularmente.

$\mathrm{O} \mathrm{pH}$ das amostras de substrato - lodo de esgoto foi determinado seguindo a metodologia sugerida por Camargo et al. (1986). As amostras foram secadas ao ar na sombra e, a seguir, passadas por uma peneira de malha de $2 \mathrm{~mm}$. Num copo plástico foram colocados $10 \mathrm{~mL}$ de substrato - lodo de esgoto e $25 \mathrm{~mL}$ de 
água destilada; e após agitar mecanicamente a 120 rpm durante 15 minutos e deixar repousar por no mínimo 30 minutos, foi feita a leitura do pH da solução.

A condutividade elétrica do extrato aquoso do substrato - lodo de esgoto foi determinada seguindo a metodologia proposta por Gillman \& Bell (1978). Em tubos plásticos de centrífuga de $50 \mathrm{~mL}$ de capacidade foram colocados $10 \mathrm{~mL}$ de substrato lodo de esgoto seco ao ar na sombra e passado por uma peneira de malha de $2 \mathrm{~mm}$, e $50 \mathrm{~mL}$ de água bidestilada. Os tubos foram agitados por duas horas a $120 \mathrm{rpm}$ em agitador reciprocante, e deixados em repouso por uma noite. No dia seguinte, os tubos foram centrifugados a $2000 \mathrm{rpm}$ por 5 minutos, e a leitura da condutividade elétrica foi feita no sobrenadante.

Os tratamentos se constituíram da combinação dos fatores doses de lodo $(0,5,10,15$ e $20 \%)$ e níveis de inóculo $(0 ; 1,5$ ou $3,0 \mathrm{~g})$, com quatro repetições, e tamanho de parcela de 4 ou 6 plântulas para o primeiro e segundo experimento, respectivamente. No primeiro experimento, foi incluído mais um nível no fator doses de lodo, o tratamento sem lodo e com adubação mineral (OA). Para a análise estatística, os dados de porcentagem de recuperação do patógeno das raízes e do substrato lodo de esgoto foram transformados em arco seno $\sqrt{ } x / 100$. As correlações entre as variáveis recuperação do patógeno, condutividade elétrica e pH foram estabelecidas. As curvas (linear ou quadrática) que descrevem o comportamento dos fatores foram selecionadas pela significância estatística.

\subsection{Efeito do lodo de esgoto na indução de supressividade a $P$. nicotianae em mudas de limão cravo, sob telado.}

\subsubsection{Experimento 1}

Mudas de limão cravo de três meses de idade, obtidas num viveiro comercial, foram transplantadas para vasos contendo misturas de solo - lodo de esgoto nas proporções de $0,5,10,15,20$ e $30 \%$ volume/volume (v/v) e infestadas com 0,8 ou $15 \mathrm{~g}$ de inóculo por vaso de $4,5 \mathrm{~L}$ de capacidade. Como testemunhas foram 
transplantadas mudas para vasos contendo solo sem lodo de esgoto, que foram adubadas semanalmente com adubo foliar completo (Agifol; $2,5 \mathrm{~mL} \mathrm{~L}^{-1}$ ), e infestadas com 0; 8 ou $15 \mathrm{~g}$ de inóculo por vaso. $O$ inóculo foi produzido em grãos de trigo (item 3.2). As mudas foram mantidas sob condições de telado e irrigadas regularmente. Aos 30, 90 e 150 dias após o transplante (dat), foram determinados a altura e o peso da matéria fresca da parte aérea, o comprimento (menos aos 150 dat) e peso da matéria fresca das raízes de duas mudas por parcela, a presença do patógeno no solo e nas raízes mediante o teste de iscas de folhas de citros, o $\mathrm{pH}$ e a condutividade elétrica das diferentes misturas de solo - lodo de esgoto (como descrito no item 3.6). A atividade microbiana do solo dos tratamentos com $15 \mathrm{~g}$ de inóculo foi avaliada pela hidrólise de diacetato de fluoresceina (FDA) e respiração microbiana medida pelo desprendimento de $\mathrm{CO}_{2}$. Também aos 150 dias foi coletada uma amostra composta de folhas das mudas para determinar seu estado nutricional mediante análise de tecido foliar (uma amostra de 100 folhas totalmente desenvolvidas e sadias por tratamento).

Para determinar a presença de $P$. nicotianae no solo, foram feitas duas placas ( $5 \mathrm{~g}$ solo, $30 \mathrm{~mL}$ água destilada, 20 iscas de folhas de citros mediando entre $3 \mathrm{a}$ $5 \mathrm{~mm}$ ) por vaso. Já para a recuperação das raízes, foram colocados $1 \mathrm{~g}$ de raízes (preferencialmente com sintomas da doença), $30 \mathrm{~mL}$ de água e 20 iscas por placa; e foram feitas duas réplicas por muda.

Para a determinação da hidrólise de FDA, foi utilizada a metodologia descrita por Boehm \& Hoitink (1992). Amostras de $5 \mathrm{~g}$ de solo - lodo de esgoto foram colocadas em frascos de $250 \mathrm{~mL}$, juntamente com $20 \mathrm{~mL}$ de tampão fosfato de potássio $60 \mathrm{mM}\left(8,7 \mathrm{~g}\right.$ de $\mathrm{K}_{2} \mathrm{HPO}_{4}$ e $1,3 \mathrm{~g}$ de $\mathrm{KH}_{2} \mathrm{PO}_{4} \mathrm{~L}^{-1}$ de água destilada; $\left.\mathrm{pH} 7,6\right)$. A reação de hidrólise de FDA (Sigma Chemical Co.) foi iniciada adicionando-se 0,2 $\mathrm{mL}$ $(400 \mu \mathrm{g})$ de solução estoque de FDA (2 mg mL $\mathrm{mL}^{-1}$ acetona). As amostras foram incubadas por $20 \mathrm{~min}$. em agitador a $200 \mathrm{rpm}$ e $25^{\circ} \mathrm{C}$. A reação foi interrompida por meio da adição de $20 \mathrm{~mL}$ de acetona por frasco. A seguir, foi feita a filtragem em papel de filtro tipo Whatman ํo 1 , sendo os filtrados recolhidos em tubos de cultura, e posteriormente tampados para evitar a evaporação da acetona. Logo após, em espectrofotômetro foi determinada a absorbância $(490 \mathrm{~nm})$ dos filtrados. A 
concentração de FDA hidrolisado ( $\mu \mathrm{g}$ FDA hidrolisado $\mathrm{g}^{-1}$ solo seco) foi obtida por meio de uma curva padrão. A curva padrão foi obtida adicionando-se FDA, nas quantidades de $0,100,200,300$ e $400 \mu \mathrm{g}$, em $5 \mathrm{~mL}$ de tampão fosfato, contido em tubos de ensaio. Os tubos foram mantidos por 60 min. em água fervente, para hidrolisar o FDA. Após a hidrólise, o FDA foi adicionado a frascos de $250 \mathrm{~mL}$ contendo $5 \mathrm{~g}$ de solo - lodo de esgoto $15 \mathrm{~mL}$ de tampão fosfato, em duas repetições. A seguir, metodologia semelhante àdescrita anteriormente foi realizada para obter-se a curva padrão entre 0 FDA hidrolisado e a absorvância.

Para a avaliação da respiração microbiana, $100 \mathrm{~g}$ de solo - lodo de esgoto foram incubados em recipientes hermeticamente fechados de 2,5 $\mathrm{L}$ de capacidade, contendo $10 \mathrm{~mL}$ de $\mathrm{KOH} 0,5 \mathrm{~N}$ (20,85 g KOH em $1 \mathrm{~L}$ de água destilada), no escuro, a 25ㄷ․ Após 14 dias de incubação, o KOH foi titulado com HCl 0,1 N $(8,5 \mathrm{~mL}$ $\mathrm{HCl}$ p.a. em $1 \mathrm{~L}$ de água destilada), segundo o método descrito por Grisi (1978), para a determinação da quantidade total de $\mathrm{CO}_{2}$ desprendido.

Para a determinação da umidade das misturas solo - lodo de esgoto foi feita a secagem de $10 \mathrm{~g}$ de solo - lodo de esgoto em estufa a $105^{\circ} \mathrm{C}$ durante $24 \mathrm{hs}$.

Os tratamentos se constituíram da combinação dos fatores doses de lodo (uma testemunha sem lodo e com adubação mineral (OA); e 0, 5, 10, 15, 20 e 30\% de lodo) e níveis de inóculo (0; 8 ou 15 g), com quatro repetições, sendo cada parcela constituída por seis mudas. Para a análise estatística, os dados de porcentagem de recuperação do patógeno das raízes e do solo - lodo de esgoto foram transformados em arco seno $\sqrt{ } x / 100$. As correlações entre as variáveis recuperação do patógeno, hidrólise do FDA, respiração microbiana, condutividade elétrica e $\mathrm{pH}$ foram estabelecidas. As curvas (linear ou quadrática) que descrevem o comportamento dos fatores foram selecionadas pela significância estatística. 


\subsubsection{Experimento 2}

Mudas de limão cravo de quatro meses de idade, obtidas de um viveiro comercial, foram transplantadas para vasos contendo misturas de solo - areia (80\% solo, 20\% areia lavada) - lodo de esgoto nas proporções de 0; 5; 7,5; 10; 15; 20 e 30\% $\mathrm{v} / \mathrm{v}$ e infestadas com $30 \mathrm{~g}$ de inóculo por vaso de $4,5 \mathrm{~L}$ de capacidade. Como testemunha foram transplantadas mudas para vasos sem inóculo e sem lodo de esgoto. O inóculo foi produzido em grãos de trigo (item 3.2). As mudas foram mantidas sob condições de telado e irrigadas regularmente. Aos 120 dias após o transplante, foram determinados a altura e o peso da matéria fresca da parte aérea das mudas, o comprimento e peso da matéria fresca das raízes, a presença do patógeno no solo e nas raízes mediante o teste de iscas de folhas de citros, o pH e a condutividade elétrica da solução do solo - areia - lodo de esgoto das diferentes misturas, a atividade microbiana do solo pela hidrólise de FDA e desprendimento de $\mathrm{CO}_{2}$. As metodologias empregadas nas determinações foram as descritas no Experimento 1 (item 3.7.1).

O delineamento experimental foi de parcelas inteiramente casualizadas, com dez mudas por tratamento. Para a análise estatística, os dados de porcentagem de recuperação do patógeno das raízes e do solo - areia - lodo de esgoto foram transformados em arco seno $\sqrt{ } \times / 100$. As correlações entre as variáveis avaliadas foram estabelecidas.

\subsection{Efeito do lodo de esgoto na indução de supressividade a $P$. nicotianae em mudas de limão cravo no campo.}

Mudas de limão cravo de três meses de idade, obtidas de um viveiro comercial, foram transplantadas para parcelas de $9 \mathrm{~m}^{2}(3 \times 3 \mathrm{~m})$ tratadas com lodo de esgoto nas proporções de $0 ; 5 ; 7,5 ; 10$ ou $15 \% \mathrm{v} / \mathrm{v}$ e infestadas com 0 ou $1250 \mathrm{~g}$ de inóculo por parcela (19 a $20 \mathrm{~g}$ de inóculo por muda). Como testemunhas foram instaladas parcelas infestadas ou não, com adubação com uréia ( $85 \mathrm{~g}$ de $\mathrm{N}$ por parcela por mês, $510 \mathrm{~g}$ no total do experimento) e adubo foliar completo (Agifol 2,5 $\mathrm{mL} \mathrm{L}^{-1}$ ) (Platt \& Opitz, 1973). As quantidades de lodo de esgoto fresco incorporadas ao solo a 
$20 \mathrm{~cm}$ de profundidade nos diferentes tratamentos foram de $0 ; 81 ; 121,5 ; 162$ e $243 \mathrm{~kg}$ por parcela $(0 ; 5 ; 7,5 ; 10$ e $15 \% \mathrm{v} / \mathrm{v}$, respectivamente), e eqüivalem a $0,372,558,744$ e $1116 \mathrm{~g}$ de $\mathrm{N}$, respectivamente. As mudas foram irrigadas por aspersão durante o experimento.

Aos 5, 15, 29, 43, 82, 118, 147 e 182 dias após incorporação do lodo de esgoto ao solo, foi determinada a atividade microbiana do solo pela hidrólise de FDA e desprendimento de $\mathrm{CO}_{2}$. Aos 29, 82, 118, 147 e 182 dias foram determinados a altura e o peso da matéria fresca da parte aérea das mudas, o peso da matéria fresca das raízes (exceto aos 182 dias), a presença do patógeno no solo e nas raízes, o pH e a condutividade elétrica da solução do solo. Ao final do experimento foi coletada uma amostra composta de folhas das mudas para determinar o estado nutricional mediante análise de tecido. As metodologias empregadas nas determinações foram iguais às empregadas nos experimentos com mudas sob telado (item 3.7.1).

Os tratamentos se constituíram da combinação dos fatores doses de lodo (testemunha sem lodo e com adubação mineral (0A); 0; 5; 7,5; 10 e 15\%) e níveis de inóculo (0 e $1250 \mathrm{~g}$ ), com quatro repetições. Para a análise estatística, os dados de porcentagem de recuperação do patógeno das raízes e do solo - lodo de esgoto foram transformados em arco seno $\sqrt{ } \mathrm{x} / 100$. As correlações entre as variáveis recuperação do patógeno, condutividade elétrica e pH foram estabelecidas, quando possível.

\subsection{Isolamento e seleção de antagonistas a P. nicotianae.}

\subsubsection{Isolamento de microrganismos do solo}

O isolamento dos microrganismos do solo foi feito mediante diluição seriada e plaqueamento em meios seletivos.

Aos 30 dias após incorporado o lodo de esgoto nas parcelas no campo, foram coletadas amostras do solo dos tratamentos com 0; 5; 7,5; 10 e $15 \%$ de lodo de esgoto e das parcelas com adubação mineral, com e sem inóculo, resultando num total 
de 12 amostras compostas (contendo solo de cada uma das repetições). As amostras de solo foram mantidas por dois dias a $25^{\circ} \mathrm{C}$, até sua utilização.

Foram preparadas diluições com $10 \mathrm{~g}$ de solo adicionados a $90 \mathrm{~mL}$ de água destilada esterilizada agitadas por 15 minutos, obtendo-se a diluição $10^{-1}$. A seguir $1 \mathrm{~mL}$ da solução foi adicionado a $9 \mathrm{~mL}$ de água esterilizada para obter uma diluição $10^{-2}$, e o processo foi repetido até obter diluições $10^{-3} \mathrm{e} 10^{-4}$. Para o isolamento dos microrganismos, $100 \mu \mathrm{L}$ de solução foi transferido para meio de cultura e homogeneizado com auxílio de alça de Drigalsky previamente desinfestada em álcool $95^{\circ}$ e flambada. Para o isolamento de bactérias foi empregado o meio de cultura Nutriente ágar - NA (NA Oxoid, $28 \mathrm{~g} \mathrm{~L}^{-1}$ ) e as diluições $10^{-3} \mathrm{e}^{-4} 0^{-4}$, para o isolamento de actinomicetos foi empregado o meio Amido caseína - AC (10 g amido; 0,3 $\mathrm{g}$ de caseína; $2 \mathrm{~g} \mathrm{KNO}_{3} ; 2 \mathrm{~g} \mathrm{NaCl} ; 2 \mathrm{~g} \mathrm{~K}_{2} \mathrm{HPO}_{4} ; 0,05 \mathrm{~g} \mathrm{MgSO}_{4} .7 \mathrm{H}_{2} \mathrm{O} ; 0,01 \mathrm{~g} \mathrm{FeSO}$. $7 \mathrm{H}_{2} \mathrm{O}$; $16 \mathrm{~g}$ ágar e $1 \mathrm{~L}$ água destilada) e as diluições $10^{-3} \mathrm{e} 10^{-4}$, e para o isolamento de fungos foi empregado o Meio de Martin ( $1 \mathrm{~g} \mathrm{~K}_{2} \mathrm{HPO}_{4} ; 0,5 \mathrm{~g} \mathrm{MgSO}_{4} .7 \mathrm{H}_{2} \mathrm{O} ; 5 \mathrm{~g}$ peptona; $10 \mathrm{~g}$ dextrose; $0,03 \mathrm{~g}$ Rosa de Bengala; $16 \mathrm{~g}$ ágar e $1 \mathrm{~L}$ água destilada) e as diluições $10^{-2} \mathrm{e}$ $10^{-3}$. Foram feitas três repetições para cada combinação meio - diluição, e as placas foram mantidas a $25^{\circ} \mathrm{C}$ até o crescimento das colônias. A avaliação foi realizada por meio de contagem do número de colônias por placa, após 2, 3 ou 6 dias para bactérias, fungos e actinomicetos, respectivamente. Foi feita uma seleção por morfologia (tamanho, cor e crescimento) das colônias a serem transferidas a tubos de ensaio contendo $5 \mathrm{~mL}$ de meio BDA (caldo de $200 \mathrm{~g}$ batata cozida, $20 \mathrm{~g}$ dextrose, $16 \mathrm{~g}$ de ágar e água destilada até completar $1 \mathrm{~L}$ ) e preservadas a $5^{\circ} \mathrm{C}$ até avaliação do antagonismo ao patógeno.

\subsubsection{Seleção de antagonistas: bioensaio}

A seleção de antagonistas foi feita mediante um bioensaio com plântulas de alfafa em placas para cultura de células com 24 compartimentos. O procedimento empregado foi modificado de Handelsman et al. $(1990,1991)$. 
Sementes de alfafa (Medicago sativa $\mathrm{L}$ ) previamente desinfestadas (submersas em álcool $70^{\circ}$ por três minutos, a seguir por mais três minutos em uma solução de hipoclorito de sódio $3 \%$, e finalmente enxaguadas por três vezes em água destilada esterilizada) foram colocadas para germinar em caixas contendo papel de germinação umedecido. Após quatro ou cinco dias, as plântulas foram transferidas aos compartimentos das placas de cultura de células (Corning com 24 compartimentos). Em cada compartimento foram colocados $1 \mathrm{~mL}$ de água destilada esterilizada, uma plântula de alfafa, um disco de $5 \mathrm{~mm}$ de diâmetro meio de cultura com micélio de $P$. nicotianae e um disco de meio de cultura contendo inóculo do fungo, actinomiceto ou bactéria a ser testado quanto àsua potencialidade como antagonista. As testemunhas foram constituídas por plântulas de alfafa em compartimentos contendo água esterilizada, e plântulas em água esterilizada e $P$. nicotianae. As placas foram mantidas por três dias a temperatura ambiente. A avaliação foi feita sob microscópio óptico com aumento de 100 vezes, onde as raízes das plântulas foram avaliadas pela presença ou não de micélio e zoosporângios de $P$. nicotianae. Para cada isolado (fungo, bactéria ou actinomiceto) foram feitas quatro repetições.

O crescimento dos microrganismos a serem testados foi obtido em temperatura ambiente em placas com diferentes meios: as bactérias em NA e incubadas por $48 \mathrm{~h}$; os fungos em BDA e incubados por uma semana e os actinomicetos em meio $\mathrm{AC}$ e incubados por uma semana a $27^{\circ} \mathrm{C} \pm 2$.

Com a finalidade de determinar a potencialidade dos isolados como antagonistas, foram feitas duas escalas de notas que discriminaram níveis de infestação com $P$. nicotianae das plântulas de alfafa crescendo na presença dos diferentes isolados. As notas variaram entre 0 - 4 para a presença de zoosporângios, e entre 0 - 3 para a presença de micélio (Tabela 3). 
Tabela 3. Escalas de notas empregadas no bioensaio para caracterizar o nível de infestação das plântulas de alfafa (Medicago sativa L.) crescendo na presença de Phytophthora nicotianae e dos isolados (fungos, actinomicetos, bactérias) avaliados como potenciais antagonistas.

\begin{tabular}{cc}
\hline \multicolumn{2}{c}{$\begin{array}{c}\text { Presença de zoosporângios de } \\
\text { P. nicotianae nas plântulas }\end{array}$} \\
\hline Nota & $\mathrm{N}^{\circ}$ zoosporângios por plântula \\
\hline 0 & 0 \\
1 & $1-5$ \\
2 & $6-10$ \\
3 & $11-50$ \\
4 & + de 51 \\
\hline
\end{tabular}

\begin{tabular}{cc}
\hline \multicolumn{2}{c}{ Presença de micélio de } \\
$\boldsymbol{P}$. nicotianae nas plântulas \\
\hline Nota & Quantidade de micélio \\
\hline 0 & Sem micélio \\
1 & Pouco \\
2 & Médio \\
3 & Muito \\
\hline
\end{tabular}

\subsubsection{Seleção de antagonistas: teste de culturas pareadas}

Um segundo teste de seleção de antagonistas foi utilizado, com a finalidade de testar os isolados selecionados no bioensaio. Para tanto, foram testados sete isolados de fungos, três de actinomicetos e dois de bactérias selecionados no bioensaio (item 3.9.2) quanto ao potencial para inibir a formação de zoosporângios $e$ reduzir a produção de micélio. $O$ crescimento dos microrganismos a serem testados foi obtido a temperatura ambiente em placas com diferentes meios: as bactérias em NA e incubadas por $48 \mathrm{~h}$; os fungos em BDA e incubados por uma semana e os actinomicetos em meio $\mathrm{AC}$ e incubados por uma semana a $27^{\circ} \mathrm{C} \pm 2$. O crescimento de $P$. nicotianae foi obtido a temperatura ambiente e por uma semana em placas com meio BDA.

Para o teste, em placas Petri de $9 \mathrm{~cm}$ de diâmetro contendo meio BDA foram transferidos um disco de meio de cultura de $5 \mathrm{~mm}$ de diâmetro com micélio de $P$. nicotianae em pleno desenvolvimento e um disco de $5 \mathrm{~mm}$ de diâmetro de meio de cultura com micélio do fungo ou actinomiceto, ou uma estria do crescimento da bactéria selecionada. Simultaneamente, os discos de meio de cultura com propágulos 
dos fungos ou actinomicetos foram colocados a $2,5 \mathrm{~cm}$ da borda da placa de Petri e distanciados a $4 \mathrm{~cm}$ do patógeno. Dois dias após colocados os discos de meio com $P$. nicotianae, as bactérias foram transferidas a $3 \mathrm{~cm}$ de distância. As placas foram mantidas a temperatura ambiente até sua avaliação. Foram feitas três repetições por isolado.

A avaliação foi feita quanto ao hiperparasitismo (crescimento sobre a colônia de $P$. nicotianae) ou antibiose (inibição do crescimento de $P$. nicotianae).

\subsection{Análises estatísticas.}

No presente trabalho, todas as análises estatísticas foram realizadas empregando o pacote estatístico SAS para Windows, versão 6.12, do SAS Institute, Cory NC, USA. 


\section{$4 \quad$ RESULTADOS}

\subsection{Efeito do lodo de esgoto na sobrevivência in vitro de $P$. nicotianae.}

Nas condições do laboratório, a sobrevivência de Phytophthora nicotianae (avaliada por meio da porcentagem de recuperação de iscas de folhas de citros com zoosporângios nas bordas e número de zoosporângios por borda de isca) foi menor quando as doses de lodo de esgoto aumentaram nas diferentes misturas solo - lodo de esgoto avaliadas, para os diferentes níveis de inóculo empregados (0, 10 e $20 \mathrm{~g}$ de inóculo por kg de mistura solo - lodo de esgoto), indicando um possível efeito supressivo do lodo (Figura 1).

No segundo experimento, os valores de $\mathrm{pH}$ das misturas diminuíram quando os níveis de lodo em ausência de inóculo aumentaram; mas na presença de inóculo, primeiro aumentaram e após diminuíram. Entretanto, os valores de condutividade elétrica mostraram uma resposta positiva aos incrementos nos níveis de lodo, independente da presença ou não do inóculo (Figura 2).

Os coeficientes de correlação $(r)$ entre a condutividade elétrica e as variáveis recuperação do patógeno e número de zoosporângios presentes nas bordas das iscas foram significativos a $5 \%$, com valores de $-0,490$ e $-0,487$, respectivamente. Por outro lado, as duas variáveis não correlacionaram-se significativamente com o pH. 

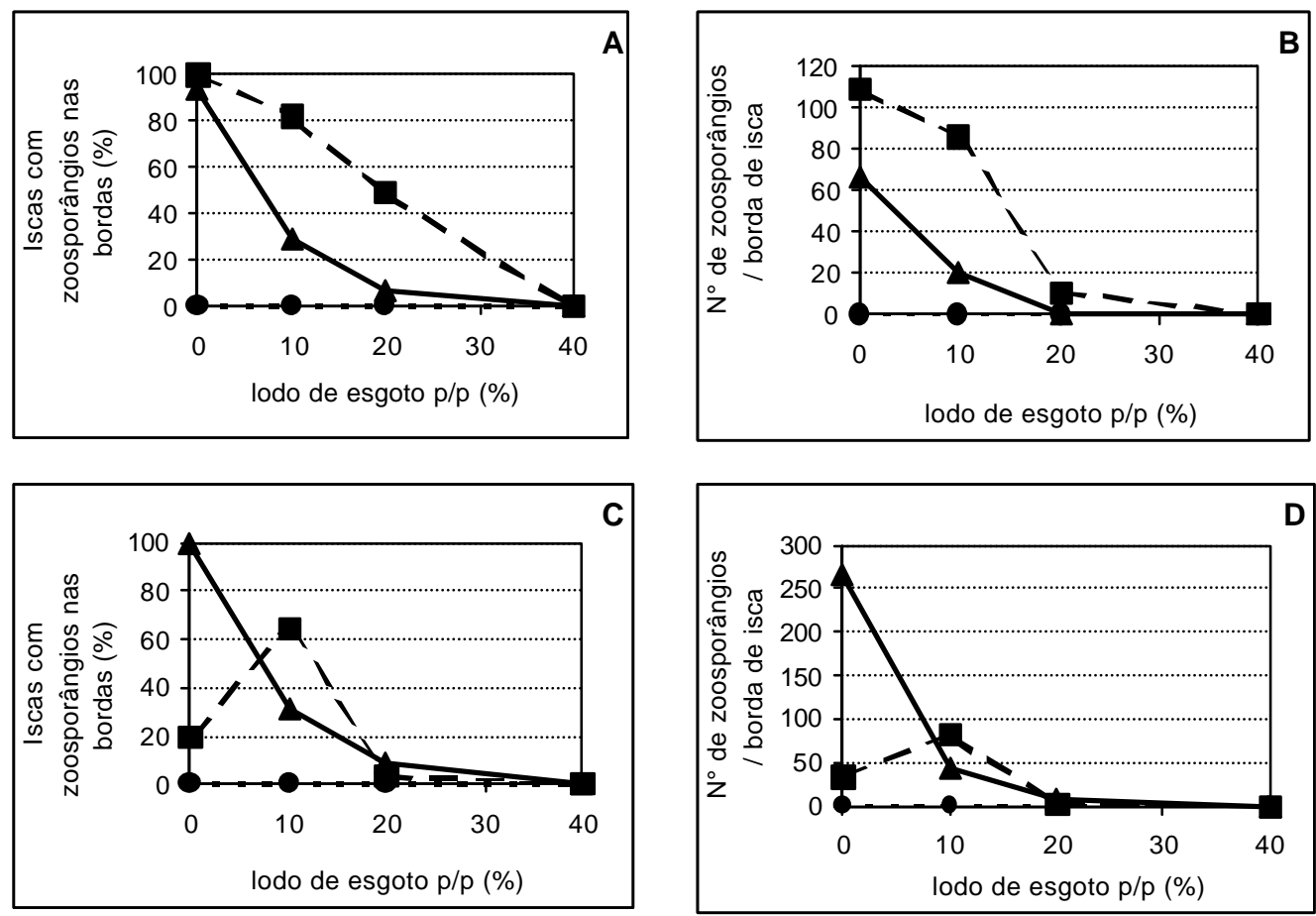

Figura 1- Sobrevivência de Phytophthora nicotianae avaliada por meio da porcentagem de recuperação em iscas de folhas de citros e número de zoosporângios por borda de isca, nas diferentes misturas solo - lodo de esgoto, para os diferentes níveis de inóculo (0-•-, $10-\mathbf{-}$ e $20-\mathbf{\Delta}-\mathrm{g} \mathrm{kg}^{-1}$ de mistura), sob condições de laboratório em dois experimentos (gráficos $\mathrm{A}$ e $\mathrm{B}$, experimento 1; gráficos C e D, experimento 2).
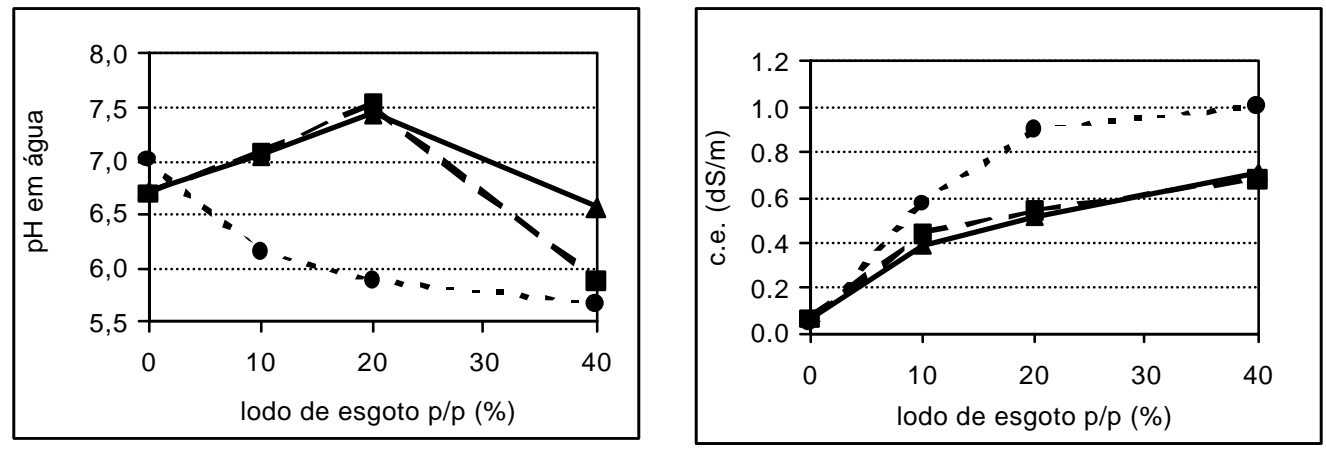

Figura 2- Efeito do lodo de esgoto no $\mathrm{pH}$ em água e na condutividade elétrica (c.e) da solução das misturas solo - lodo de esgoto, nas diferentes misturas solo - lodo de esgoto, para os diferentes níveis de inóculo (0-•-, $10-\mathbf{-}$ - e $20-\mathbf{\Delta}-\mathrm{g} \mathrm{kg}^{-1}$ de mistura), sob condições de laboratório, no experimento 2 . 


\subsection{Efeito dos extratos do lodo de esgoto no crescimento in vitro de $P$. nicotianae}

Dos extratos avaliados, o extrato ácido do tratamento com lodo de esgoto apresentou uma redução significativa no crescimento da colônia de $P$. nicotianae, atingindo um diâmetro médio de 2,27 cm aos 9 dias após a repicagem, quando a testemunha atingiu $9 \mathrm{~cm}$ (Tabela 4).

Tabela 4. Diâmetros médios das colônias de Phytophthora nicotianae isolado IAC 01/95 aos 2, 4, 6 e 9 dias após a repicagem e área abaixo a curva de crescimento das colônias aos nove dias (AACC), crescendo em meio de cenoura (MC) contendo extratos aquosos, ácidos $\left(\mathrm{H}_{2} \mathrm{SO}_{4}\right)$ ou básicos $(\mathrm{KOH})$ de lodo de esgoto (LE) em areia.

\begin{tabular}{|c|c|c|c|c|c|c|c|c|c|c|}
\hline \multirow{3}{*}{$\begin{array}{l}\text { Tratamentos } \\
\text { Testemunha (MC) }\end{array}$} & \multicolumn{8}{|c|}{ Dias após a repicagem } & \multirow{2}{*}{\multicolumn{2}{|c|}{ AACC }} \\
\hline & \multicolumn{2}{|c|}{2} & \multicolumn{2}{|c|}{4} & \multicolumn{2}{|c|}{6} & \multicolumn{2}{|r|}{9} & & \\
\hline & $2,95^{1}$ & $a b^{2}$ & 5,43 & $a b$ & 8,68 & a & 9,00 & $a$ & 52,56 & a \\
\hline Areia + água & 2,79 & $b$ & 5,40 & $a b$ & 8,68 & a & 9,00 & a & 52,18 & a \\
\hline Areia $+\mathrm{KOH}$ & 2,23 & $d$ & 4,41 & C & 8,79 & b & 8,82 & a & 44,61 & b \\
\hline Areia $+\mathrm{H}_{2} \mathrm{SO}_{4}$ & 1,49 & C & 4,63 & C & 7,08 & b & 8,65 & a & 45,52 & b \\
\hline Areia + LE + água & 3,09 & a & 4,89 & bc & 7,28 & $b$ & 8,73 & a & 47,86 & b \\
\hline Areia + LE + KOH & 3,00 & $a b$ & 5,68 & a & 8,79 & a & 9,00 & a & 53,44 & a \\
\hline Areia $+\mathrm{LE}+\mathrm{H}_{2} \mathrm{SO}_{4}$ & 1,85 & e & 2,05 & $d$ & 2,19 & $C$ & 2,27 & $b$ & 17,28 & C \\
\hline
\end{tabular}

${ }^{1}$ diâmetro médio das colônias em $\mathrm{cm}$.

2 Dados seguidos da mesma letra, na coluna, não diferem significativamente (Teste de Duncan, ao nível de $5 \%$ de probabilidade). 


\subsection{Efeito do lodo de esgoto na indução de supressividade a $P$. nicotianae em plântulas de limão cravo, sob telado.}

Nos dois experimentos, observaram-se diferenças significativas entre tratamentos para as variáveis peso da matéria fresca da parte aérea e altura das plântulas, com incrementos positivos quando os níveis de lodo de esgoto aumentaram (Figura 3). Entretanto, no experimento 1, para as variáveis comprimento e peso da matéria fresca das raízes não foram verificadas diferenças significativas entre os tratamentos, mas no experimento 2 foram verificadas para só para a variável peso da matéria fresca das raízes (Figura 3) pois o comprimento não foi determinado. No experimento 1 os valores médios de comprimento das raízes variaram entre 9,0 e 11,5 $\mathrm{cm}$.

No experimento 1, os tratamentos com adubação mineral comportaramse como os tratamentos com $10 \%$ de lodo para a variável altura, e como os com $20 \%$ e $30 \%$ para as variáveis peso da matéria fresca da parte aérea e peso da matéria fresca das raízes, respectivamente (Figura 3).

Os valores de $\mathrm{pH}$ em água e da condutividade elétrica mostraram respostas ao aumento dos níveis de lodo de esgoto nos tratamentos (Figura 4). A condutividade elétrica sempre aumentou quando os níveis de lodo de esgoto aumentaram. No caso do $\mathrm{pH}$, apesar dos dados apresentarem alguma variação nas tendeências, de modo geral, observou-se uma diminuição do pH quando os níveis de lodo aumentaram. 

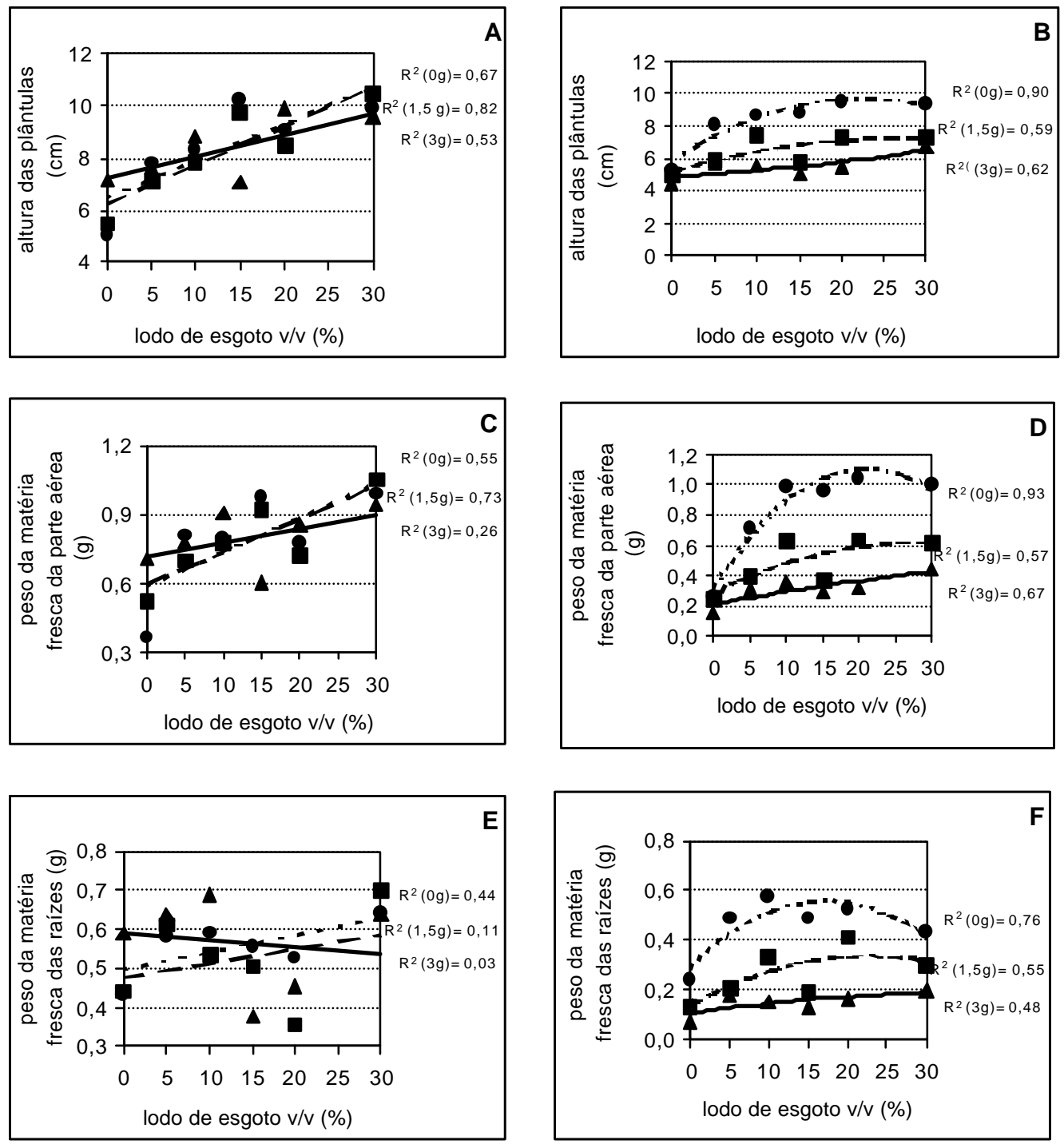

Figura 3- Efeito do lodo de esgoto na altura, peso da matéria fresca da parte aérea e peso da matéria fresca das raízes das plântulas de limão cravo (Citrus lemonia) aos 90 dias após o transplante, para os diferentes níveis de inóculo

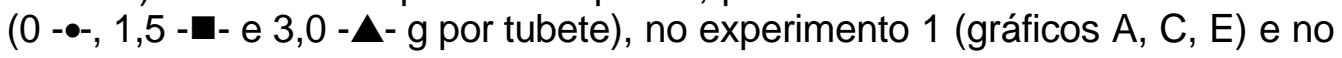
experimento 2 (gráficos $\mathrm{B}, \mathrm{D}, \mathrm{F}$ ). 

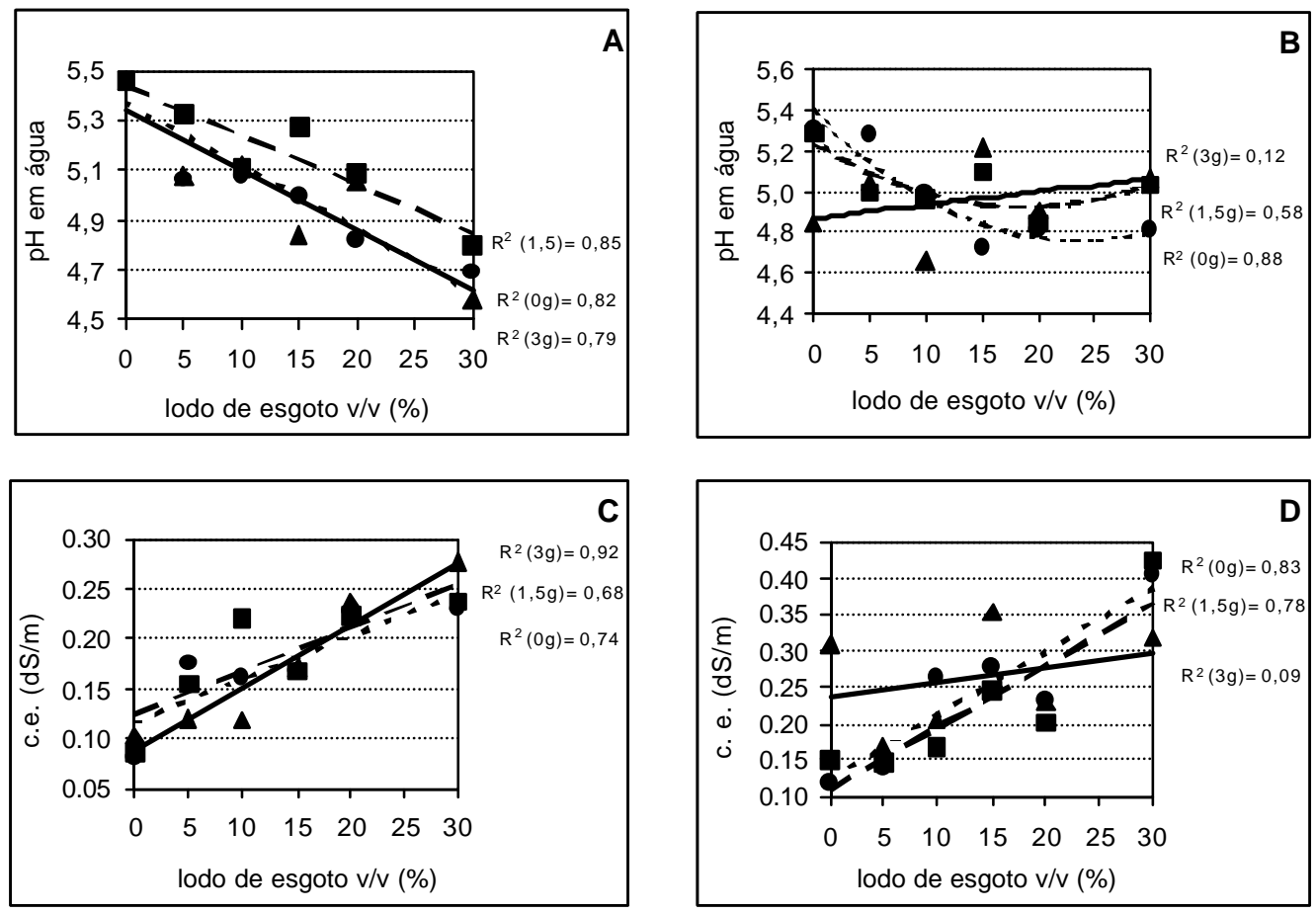

Figura 4- Efeito do lodo de esgoto no $\mathrm{pH}$ em água e condutividade elétrica (c.e.) da solução substrato - lodo de esgoto aos 90 dias após o transplante, para os diferentes níveis de inóculo (0 - •-, 1,5 - - e 3,0 - $\mathbf{-}$ - $g$ por tubete), no experimento 1 (gráficos $\mathrm{A}, \mathrm{C}$ ) e no experimento 2 (gráficos $\mathrm{B}, \mathrm{D}$ ).

Para a recuperação de $P$. nicotianae das raízes das plântulas e das misturas substrato-lodo de esgoto, nos dois experimentos observaram-se diferenças significativas entre tratamentos. As porcentagens de recuperação do patógeno diminuíram quando os níveis de lodo de esgoto aumentaram (Figura 5). Os valores máximos de recuperação do substrato e das raízes para os tratamentos sem lodo foram de 50 e $46 \%$ no experimento 1 , e de 25 e 15\% no experimento 2, respectivamente. Os valores mínimos de recuperação do substrato e das raízes para os tratamentos com $30 \%$ de lodo foram de 24 e $11,6 \%$ no experimento 1, e de 8 e $0,5 \%$ no experimento 2 , respectivamente. 

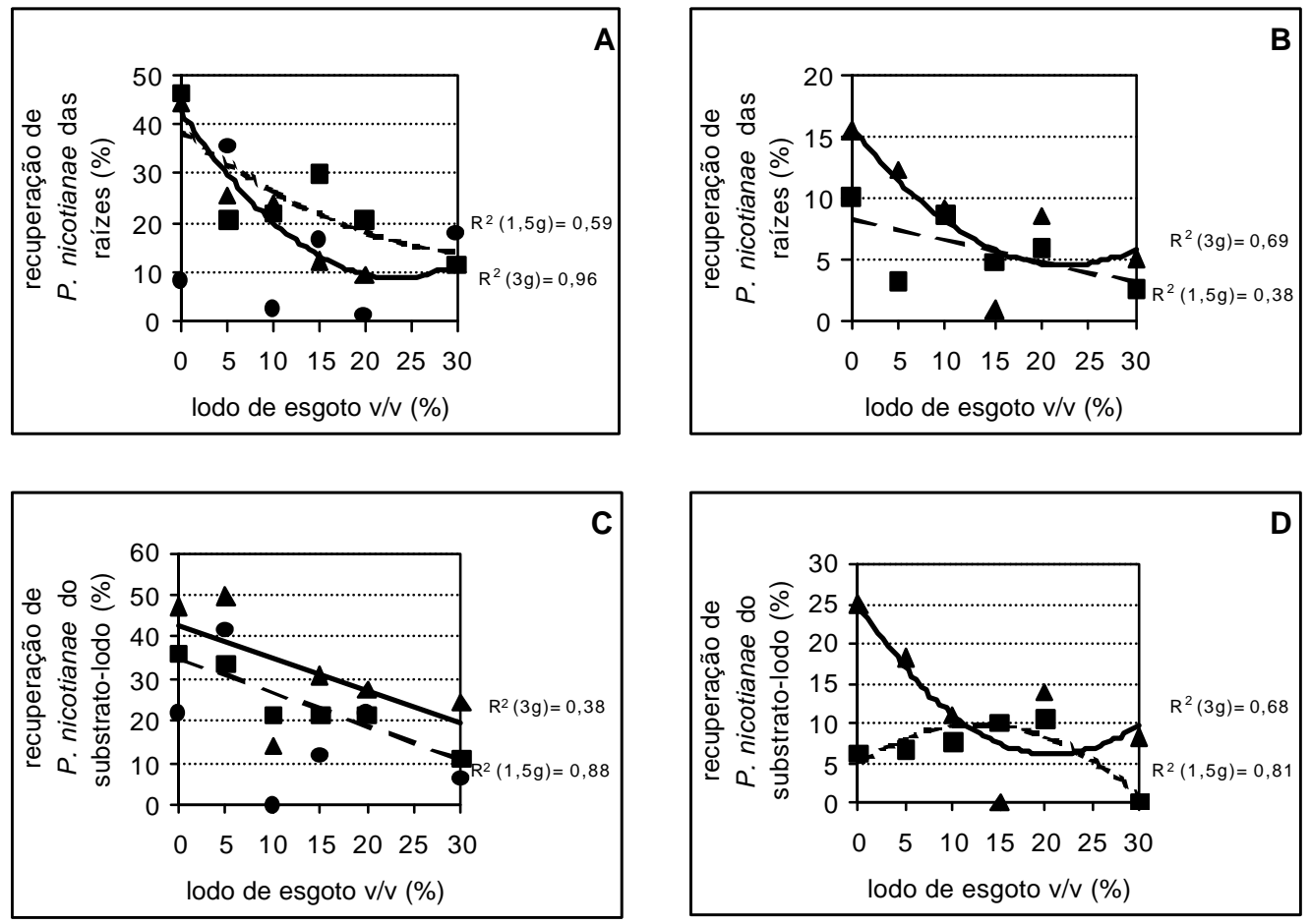

Figura 5- Efeito do lodo de esgoto na recuperação de Phytophthora nicotianae das raízes das plântulas de limão cravo (Citrus lemonia) e das misturas substrato - lodo de esgoto, mediante o teste de iscas de folhas de citros, aos 90 dias após o transplante, para os diferentes níveis de inóculo (0 -•-, 1,5 - - e 3,0 $\Delta$ - g por tubete), no experimento 1 (gráficos $A, C)$ e no experimento 2 (gráficos B, D).

Os valores de recuperação do patógeno no experimento 1 para os tratamento sem lodo e adubo mineral foram os maiores do experimento, com valores de 46 e 55\% para a recuperação das raízes, e de 38 e 50\% para a recuperação do substrato, para os tratamentos com 1,5 e 3,0 g inóculo por tubete, respectivamente.

No experimento 1, os dados da recuperação do patógeno das raízes correlacionaram-se negativamente com os valores de condutividade elétrica $(r=-0,49$; $\mathrm{P}=0,024)$ e positivamente com os de $\mathrm{pH}(\mathrm{r}=0,513 ; \mathrm{P}=0,017)$, e tiveram igual tendência no experimento 2 , mas não foram significativos. Os dados de recuperação 
do patógeno do solo tiveram igual tendência aos das raízes, mas não foram significativos para nenhum dos experimentos.

Os valores de recuperação do patógeno, observados no experimento 1 para os tratamentos sem inóculo, explicam-se pela contaminação ocorrida entre parcelas durante o desenvolvimento do experimento, devido à proximidade entre as mesmas (Figura 5).

No decorrer dos experimentos, morreram 20 plântulas em cada um deles. A recuperação de $P$. nicotianae dessas plântulas e do substrato - lodo de esgoto foi de $60 \%$ no experimento 1 , e de $100 \%$ no experimento 2 .

\subsection{Efeito do lodo de esgoto na indução de supressividade a $P$. nicotianae em mudas de limão cravo, sob telado}

\subsubsection{Experimento 1}

Aos 30 dias após transplante (dat) não foram observadas diferenças significativas entre tratamentos para todas as variáveis avaliadas. Para a variável comprimento das raízes, aos 90 dat tampouco foram observadas diferenças significativas entre tratamentos, com valores entre 33 e $40 \mathrm{~cm}$, coincidindo com a profundidade dos vasos.

Aos 90 e 150 dat, observaram-se diferenças significativas entre tratamentos para as variáveis altura, peso da matéria fresca da parte aérea e das raízes das mudas, com incrementos positivos quando os níveis de lodo de esgoto aumentaram (Figura 6). O fator doses de lodo foi o responsável pelas diferenças significativas entre tratamentos, e não houve efeito do fator inóculo, nem da interação dos dois fatores.

Os tratamentos com adubação mineral só foram superiores aos tratamentos sem lodo. Aos 90 dat, foram superiores para as variáveis altura e peso da 
matéria fresca da parte aérea, mas inferiores para o peso da matéria fresca das raízes. Em média, foram $6,4 \%$ e $24,9 \%$ superiores; e $25 \%$ inferiores, respectivamente. Aos 150 dat, e em média, os tratamentos com adubo mineral foram superiores aos tratamentos sem lodo em $33 \%, 76 \%$ e $45 \%$ para as variáveis altura, peso da matéria fresca da parte aérea e das raízes, respectivamente.
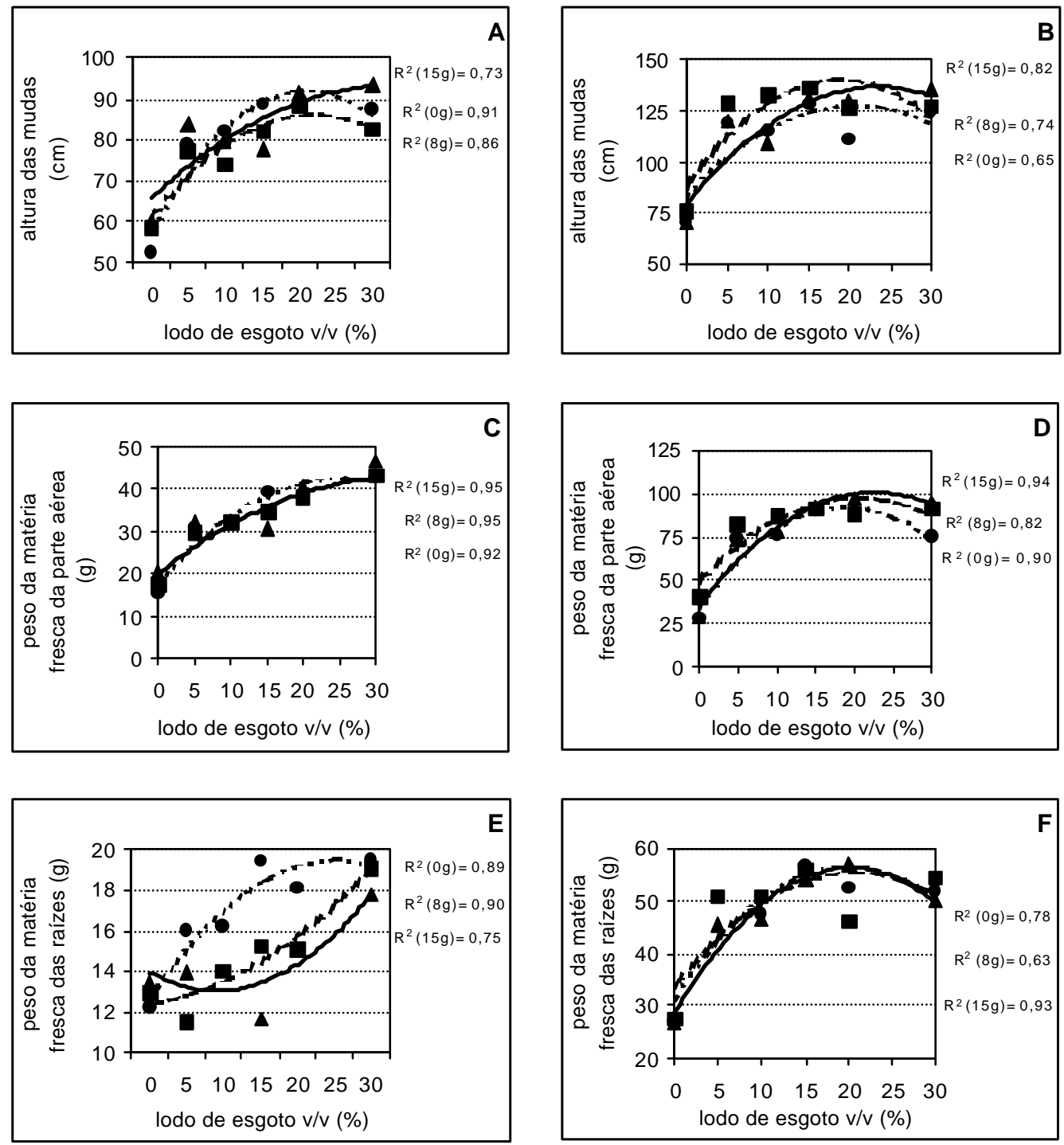

Figura 6- Efeito do lodo de esgoto na altura, peso da matéria fresca da parte aérea e das raízes das mudas de limão cravo (Citrus lemonia) aos 90 (gráficos $\mathrm{A}, \mathrm{C}$, E) e 150 dias após o transplante (gráficos B, D, F), para os diferentes níveis de inóculo (0 -•-, 8 - - e 15 - $\mathbf{\Delta}$ - g por vaso), no experimento 1 
Os valores de condutividade elétrica da solução do solo - lodo de esgoto aos 30, 90 e 150 dat também apresentaram diferenças significativas entre tratamentos com incrementos positivos quando os níveis de lodo de esgoto aumentaram, e não houve efeito do fator inóculo, nem da interação lodo $x$ inóculo. $\mathrm{O} \mathrm{pH}$ em água não apresentou diferenças significativas entre tratamentos (Figura 7). Os tratamentos com adubação química apresentaram valores semelhantes aos tratamentos sem lodo.
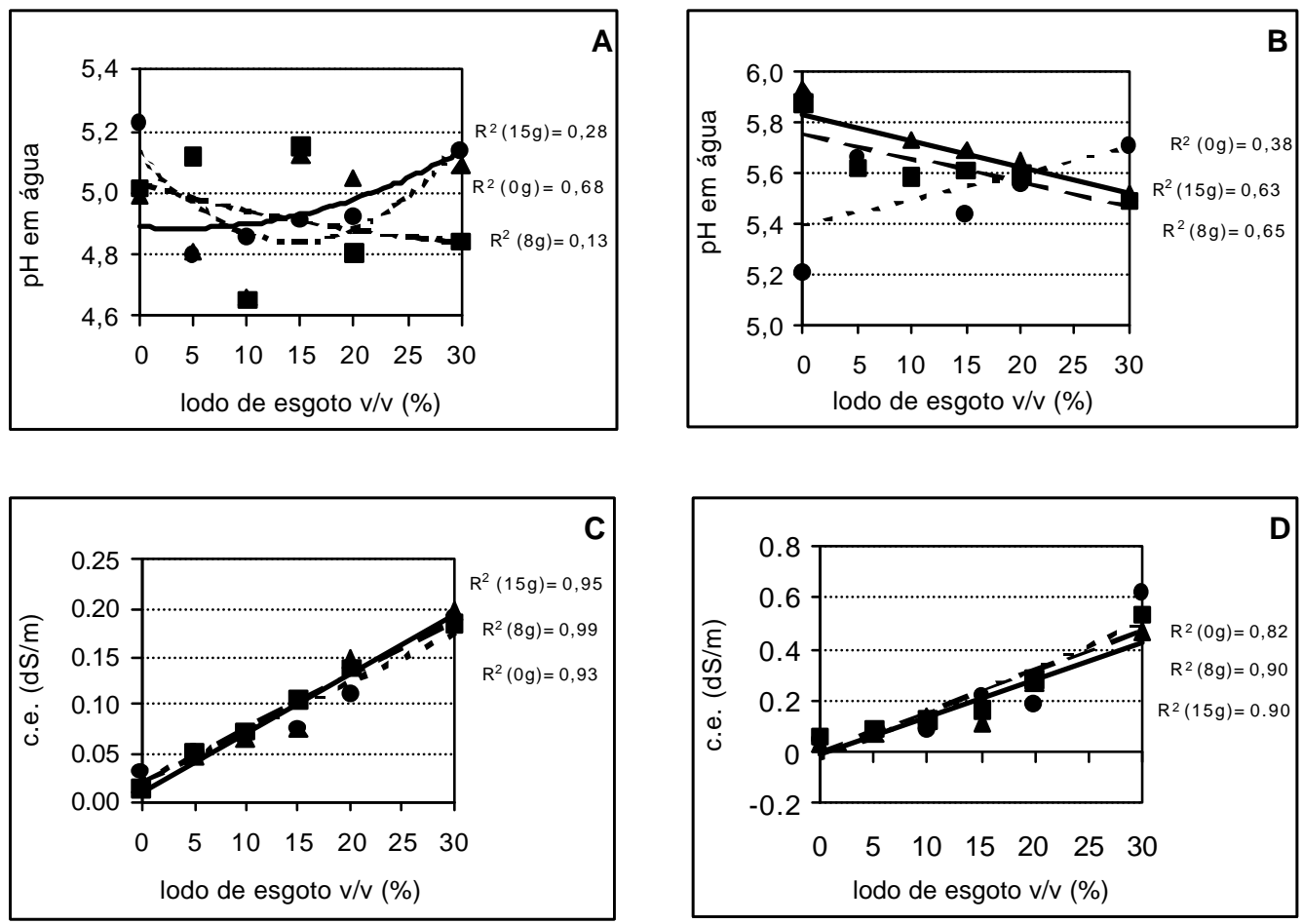

Figura 7- Efeito do lodo de esgoto no pH em água e na condutividade elétrica (c.e.) da solução solo - lodo de esgoto aos 90 (gráficos A, C) e 150 dias após o transplante (gráficos $\mathrm{B}, \mathrm{D})$, respectivamente; para os diferentes níveis de

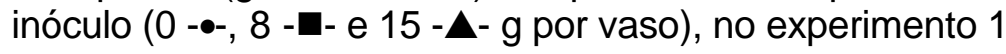


Dos resultados da análise do tecido foliar (macro e micronutrientes) observa-se que, para o nitrogênio $(\mathrm{N})$, os tratamentos sem lodo e sem adubação mineral foram deficientes para esse nutriente, e os tratamentos com níveis de lodo de esgoto iguais ou superiores a 10\% tiveram excesso. Contrariamente, para o potássio $(\mathrm{K})$, os tratamentos sem lodo e com adubo mineral tiveram teores do elemento nas folhas em excesso, enquanto os tratamentos com lodo tiveram valores ótimos para esse nutriente, fato que pode se explicar pois o lodo de esgoto em geral é deficiente para este nutriente. Por último, todos os tratamentos apresentaram níveis de cobre $(\mathrm{Cu})$ e ferro (Fe) em excesso, mas nos tratamentos sem lodo os valores de Cu foram maiores. Neste experimento, o lodo estaria indicando um possível efeito compensador, principalmente para o K (Tabela 5). 
Tabela 5. Efeito do lodo de esgoto na composição do tecido foliar das mudas de limão cravo (Citrus lemonia) aos 150 dias após transplante, no experimento 1, em casa de vegetação.

\begin{tabular}{|c|c|c|c|c|c|c|c|c|c|c|}
\hline Trat. & $\begin{array}{c}\mathbf{N} \\
\mathrm{g} \mathrm{kg}^{-1}\end{array}$ & $\begin{array}{c}\mathbf{K} \\
\mathrm{g} \mathrm{kg}^{-1}\end{array}$ & $\begin{array}{c}\mathbf{P} \\
\mathrm{g} \mathrm{kg}^{-1}\end{array}$ & $\begin{array}{c}\text { Ca } \\
\mathrm{g} \mathrm{kg}^{-1}\end{array}$ & $\begin{array}{c}\text { Mg } \\
\mathrm{g} \mathrm{kg}^{-1}\end{array}$ & $\begin{array}{c}\text { B } \\
\mathrm{mg} \mathrm{kg}^{-1}\end{array}$ & $\begin{array}{c}\mathrm{Cu} \\
\mathrm{mg} \mathrm{kg}^{-1}\end{array}$ & $\begin{array}{c}\mathrm{Fe} \\
\mathrm{mg} \mathrm{kg}^{-1}\end{array}$ & $\begin{array}{c}\text { Mn } \\
\mathrm{mg} \mathrm{kg}^{-1}\end{array}$ & $\begin{array}{c}\mathbf{Z n} \\
\mathrm{mg} \mathrm{kg}^{-1}\end{array}$ \\
\hline & \multicolumn{10}{|c|}{ Tratamentos sem inóculo } \\
\hline $0 \%$ lodo $^{1}$ & $21,8^{3}$ & 21,0 & 1,2 & 29,6 & 3,0 & 63,0 & 699 & 200 & 31 & 30,2 \\
\hline $0 \%+A^{2}$ & 29,5 & 12,2 & 1,9 & 34,9 & 3,0 & 68,3 & 103 & 205 & 26 & 26,2 \\
\hline $5 \%$ lodo & 23,7 & 8,8 & 1,8 & 37,2 & 2,6 & 42,6 & 105 & 165 & 40 & 33,5 \\
\hline $10 \%$ lodo & 27,2 & 9,3 & 1,9 & 43,0 & 2,8 & 47,6 & 207 & 193 & 61 & 48,3 \\
\hline $15 \%$ lodo & 28,2 & 7,8 & 1,6 & 40,6 & 2,5 & 49,6 & 145 & 186 & 51 & 43,1 \\
\hline $20 \%$ lodo & 32,0 & 8,3 & 1,5 & 41,1 & 2,6 & 51,1 & 150 & 201 & 60 & 46,0 \\
\hline \multirow[t]{2}{*}{$30 \%$ lodo } & 33,7 & 8,8 & 1,3 & 42,2 & 2,8 & 49,7 & 175 & 229 & 85 & 57,0 \\
\hline & \multicolumn{10}{|c|}{ Tratamentos com $8 \mathrm{~g}$ de inóculo de Phytophthora nicotianae por vaso } \\
\hline $0 \%$ lodo & 21,8 & 18,5 & 1,4 & 33,7 & 3,4 & 43,6 & 693 & 221 & 32 & 31,2 \\
\hline $0 \%+A$ & 29,8 & 11,7 & 1,9 & 33,7 & 2,9 & 68,9 & 143 & 195 & 30 & 27,8 \\
\hline $5 \%$ lodo & 23,5 & 9,8 & 1,8 & 38,6 & 3,0 & 42 & 120 & 135 & 48 & 36,6 \\
\hline $10 \%$ lodo & 27,8 & 8,3 & 1,8 & 40,4 & 2,6 & 43,5 & 193 & 210 & 59 & 45,2 \\
\hline $15 \%$ lodo & 31,1 & 8,8 & 1,8 & 43,7 & 2,7 & 50,3 & 218 & 229 & 72 & 54,7 \\
\hline $20 \%$ lodo & 31,5 & 8,8 & 1,5 & 39,3 & 2,7 & 52,6 & 135 & 169 & 75 & 49,8 \\
\hline \multirow[t]{2}{*}{$30 \%$ lodo } & 34,5 & 8,3 & 1,5 & 41,5 & 2,9 & 53,0 & 194 & 222 & 99 & 59,4 \\
\hline & \multicolumn{10}{|c|}{ Tratamentos com $15 \mathrm{~g}$ de inóculo de Phytophthora nicotianae por vaso } \\
\hline $0 \%$ lodo & 22,7 & 17,6 & 1,4 & 33,1 & 3,3 & 49,6 & 535 & 225 & 33 & 31,0 \\
\hline $0 \%+A$ & 28,3 & 9,8 & 1,3 & 35,7 & 3,1 & 72,8 & 114 & 186 & 36 & 25,3 \\
\hline $5 \%$ lodo & 24,1 & 8,8 & 1,9 & 36,7 & 2,7 & 40,9 & 160 & 189 & 46 & 34,7 \\
\hline $10 \%$ lodo & 27,3 & 9,3 & 1,7 & 39,8 & 2,5 & 47,4 & 180 & 216 & 64 & 47,6 \\
\hline $15 \%$ lodo & 28,3 & 8,3 & 1,9 & 44,0 & 2,6 & 50,8 & 157 & 168 & 61 & 45,8 \\
\hline $20 \%$ lodo & 32,0 & 8,8 & 1,4 & 38,3 & 2,6 & 51,5 & 159 & 151 & 77 & 50,1 \\
\hline \multirow[t]{2}{*}{$30 \%$ lodo } & 35,9 & 8,3 & 1,4 & 43,4 & 2,9 & 51,8 & 166 & 216 & 100 & 63,3 \\
\hline & \multicolumn{10}{|c|}{ Valores de referência } \\
\hline BAIXO $^{4}$ & $<23,9$ & $<6,9$ & $<1,1$ & $<29$ & $<1,9$ & $<30$ & $<5$ & $<59$ & $<24$ & $<24$ \\
\hline ÓTIMO & $24-26$ & $7-10,9$ & $1,2-1,6$ & $30-55$ & $2-3$ & $31-100$ & $6-16$ & $60-120$ & $25-200$ & $25-100$ \\
\hline ALTO & $>27$ & $>11$ & $>1,7$ & $>56$ & $>4$ & $>101$ & $>17$ & $>121$ & $>300$ & $>110$ \\
\hline
\end{tabular}


A atividade microbiana do solo avaliada pela hidrólise de FDA e respiração microbiana, mostrou diferenças significativas entre tratamentos, com incrementos positivos quando aumentaram os níveis de lodo. Também, observou-se uma atividade decrescente no tempo, especialmente quando avaliada pela respiração microbiana (desprendimento de $\mathrm{CO}_{2}$ ) (Tabela 6).

Tabela 6. Efeito do lodo de esgoto na atividade microbiana do solo dos tratamentos com $15 \mathrm{~g}$ de inóculo de Phytophthora nicotianae por vaso, avaliada pela hidrólise de diacetato de fluoresceina (FDA) e respiração microbiana $\left(\mathrm{CO}_{2}\right)$ aos 60, 90 e 150 dias após o transplante (dat) das mudas de limão cravo (Citrus lemonia), no experimento 1.

\begin{tabular}{|c|c|c|c|c|c|c|c|}
\hline \multirow{2}{*}{ Tratamentos } & \multicolumn{3}{|c|}{$\mu \mathrm{g}$ FDA hidrolisado $\mathrm{g} \mathrm{s} \mathrm{s}^{-1} \mathrm{~min}^{-1}$} & \multicolumn{4}{|c|}{$\mathrm{mg} \mathrm{CO}_{2} \mathrm{~g} \mathrm{~s} \mathrm{~s}^{-1}$} \\
\hline & 30 dat & 90 dat & 150 dat & $30 \mathrm{da}$ & & 90 dat & $150 \mathrm{dat}$ \\
\hline $\begin{array}{c}\text { adubação } \\
\text { mineral }\end{array}$ & $2,00 c^{2}$ & $2,27 \mathrm{de}$ & $2,76 \mathrm{bcd}$ & 0,44 & $b$ & $0,23 d$ & $0,22 b$ \\
\hline $0 \%$ lodo & $2,17 \quad c$ & $2,58 \mathrm{~cd}$ & $2,40 \mathrm{~d}$ & 0,24 & b & $0,30 \mathrm{~d}$ & $0,27 \mathrm{~b}$ \\
\hline $5 \%$ lodo & $2,62 \mathrm{c}$ & $2,10 \mathrm{c}$ & $2,50 \mathrm{~cd}$ & 0,87 & a & $0,34 \mathrm{~cd}$ & $0,31 \mathrm{~b}$ \\
\hline $10 \%$ lodo & $3,42 \quad b$ & $2,68 \mathrm{bc}$ & $2,80 \mathrm{bcd}$ & 1,05 & a & $0,46 \mathrm{c}$ & 0,32 \\
\hline $15 \%$ lodo & $3,61 a b$ & $2,70 \mathrm{bc}$ & $2,95 \quad b$ & 0,92 & a & $0,70 \quad b$ & 0,34 \\
\hline $20 \%$ lodo & $4,11 a b$ & $2,99 \mathrm{~b}$ & $2,85 b c$ & 1,04 & a & $0,93 \quad a$ & 0,49 \\
\hline $30 \%$ lodo & 4,20 a & 3,38 a & 3,37 a & 1,01 & a & 0,95 a & $0,54 a$ \\
\hline
\end{tabular}

A recuperação de $P$. nicotianae das raízes das mudas e das misturas solo - lodo de esgoto só foi possível aos 150 dat, apesar de baixa incidência, sem diferenças significativas entre tratamentos, mas com uma tendência a diminuir quando os níveis de lodo aumentaram (Figura 8). Quanto à recuperação do solo, só foi possível nos tratamentos com $20 \%$ de lodo de esgoto e 8 e $15 \mathrm{~g}$ de inóculo, com valores de $7,5 \%$ e $5 \%$, respectivamente. 


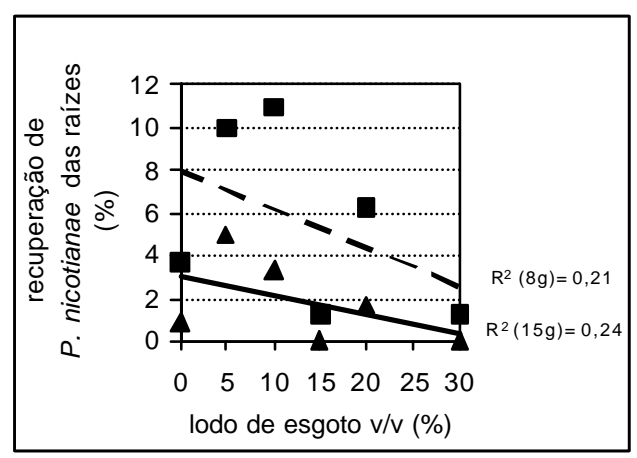

Figura 8- Efeito do lodo de esgoto na recuperação de Phytophthora nicotianae das raízes das mudas de limão cravo (Citrus lemonia), mediante o teste de iscas de folhas de citros, aos 150 dias após o transplante, para os diferentes níveis de inóculo (8 - - e 15 - $\mathbf{\Delta}$ - g por vaso), no experimento 1.

Embora baixos, os valores da recuperação do patógeno das raízes e do solo correlacionaram-se negativa e significativamente com os valores da hidrólise de FDA e da respiração microbiana, positiva e significativamente com os valores do $\mathrm{pH}$, mas não correlacionaram-se com os valores da condutividade elétrica (Tabela 7).

Tabela 7. Correlação linear simples entre as variáveis recuperação do patógeno das raízes das mudas de limão cravo (Citrus lemonia), recuperação do patógeno do solo, hidrólise de diacetato de fluoresceina (FDA), respiração microbiana do solo $\left(\mathrm{CO}_{2}\right), \mathrm{pH}$ e condutividade elétrica (c.e.), aos 150 dias após o transplante no experimento 1 .

\begin{tabular}{|c|c|c|c|c|c|c|}
\hline & $\begin{array}{c}\text { Recuperação } \\
\text { das raízes }\end{array}$ & $\begin{array}{c}\text { Recuperação } \\
\text { do solo }\end{array}$ & FDA & $\mathrm{CO}_{2}$ & $\mathrm{pH}$ & c.e. \\
\hline $\begin{array}{c}\text { Recuperação } \\
\text { das raízes }\end{array}$ & ----- & $0,94^{* \star}$ & $-0,94^{* *}$ & $-0,82^{* *}$ & $0,74^{* \star}$ & 0,08 n.s. \\
\hline $\begin{array}{c}\text { Recuperação } \\
\text { do solo }\end{array}$ & & ----- & $-0,99$ ** & $-0,90^{* *}$ & 0,60 ** & $-0,26$ n.s. \\
\hline FDA & & & ----- & 0,93 ** & $-0,84^{* *}$ & 0,79 ** \\
\hline $\mathrm{CO}_{2}$ & & & & ----- & $-0,70^{* *}$ & 0,32 n.s. \\
\hline $\mathrm{pH}$ & & & & & ---- & 0,01 n.s. \\
\hline c.e. & & & & & & ---- \\
\hline
\end{tabular}

'Significativo ao 1\% de probabilidade pelo teste de Pearson, n.s.= não significativo. 


\subsubsection{Experimento 2}

As variáveis altura, peso da matéria fresca da parte aérea e das raízes, comportaram-se de forma semelhante ao experimento anterior, com diferenças significativas entre tratamentos (Tabela 8), quando foram empregados $30 \mathrm{~g}$ de inóculo por muda e a avaliação feita aos 120 dias após o transplante. Também $\circ \mathrm{pH}$ e a condutividade elétrica tiveram um comportamento semelhante ao experimento 1, com tendências crescentes para a condutividade elétrica e decrescentes para o $\mathrm{pH}$ quando os níveis de lodo de esgoto aumentaram, respectivamente (Tabela 8).

Com o método de hidrólise de FDA, os resultados mostraram que os solos tratados com lodo de esgoto apresentaram atividade microbiana significativamente maior do que os solos não tratados (Tabela 8). A mesma tendência foi observada para a respiração microbiana, porém com incrementos significativos na atividade microbiana em resposta ao aumento na dose de lodo.

Tabela 8. Efeito do lodo de esgoto na altura, peso da matéria fresca da parte aérea (pfpa) e das raízes (pfr) das mudas de limão cravo (Citrus lemonia), no pH e condutividade elétrica (c.e.) do solo - areia - lodo de esgoto, e na atividade microbiana do solo (FDA e respiração microbiana) aos 120 dias após o transplante, no experimento 2 .

\begin{tabular}{|c|c|c|c|c|c|c|c|}
\hline Tratamento & $\begin{array}{c}\text { altura } \\
\mathrm{cm}\end{array}$ & $\begin{array}{c}\text { pfpa } \\
g\end{array}$ & $\begin{array}{c}\text { pfr } \\
\text { g }\end{array}$ & $\begin{array}{c}\text { pH } \\
\text { em água }\end{array}$ & $\begin{array}{c}\text { c.e. } \\
\text { dS. } m^{-1}\end{array}$ & FDA $^{3}$ & $\begin{array}{c}\text { respiração } \\
\text { microbiana }^{4}\end{array}$ \\
\hline Testemunha $^{1}$ & $48,4 c^{5}$ & $28,2 \mathrm{c}$ & $40,8 \mathrm{~cd}$ & $5,94 \quad a$ & $0,05 \mathrm{de}$ & $1,73 \mathrm{~b}$ & $0,27 d$ \\
\hline $0 \%$ lodo $^{2}$ & $52,5 \mathrm{bc}$ & $34,5 \mathrm{c}$ & $40,5 \mathrm{~cd}$ & $5,75 \mathrm{~b}$ & $0,04 \mathrm{e}$ & $1,67 \mathrm{~b}$ & $0,43 \mathrm{~cd}$ \\
\hline $5 \%$ lodo & $64,5 a b$ & 72,9 a & $83,1 \quad a$ & $5,10 \mathrm{~d}$ & 0,08 cde & $2,60 \mathrm{a}$ & $0,53 \mathrm{c}$ \\
\hline 7,5\% lodo & 68,6 a & $59,3 a b$ & $65,4 a b$ & $5,08 \mathrm{~d}$ & $0,11 \mathrm{~cd}$ & $2,41 \quad a$ & $0,78 \quad b$ \\
\hline $10 \%$ lodo & $65,6 a b$ & $61,6 a b$ & 49,9 bc & $5,08 d$ & $0,14 \mathrm{c}$ & $2,33 a$ & $0,88 \mathrm{~b}$ \\
\hline $15 \%$ lodo & $49,9 \mathrm{c}$ & $33,1 \quad c$ & $35,1 \mathrm{~cd}$ & $5,40 \mathrm{c}$ & $0,23 \mathrm{~b}$ & $2,60 a$ & $1,09 \quad a$ \\
\hline $20 \%$ lodo & 57,0 abc & $47,5 \mathrm{bc}$ & $28,7 d$ & $5,39 \mathrm{c}$ & $0,24 \mathrm{~b}$ & $2,45 a$ & $1,20 \quad a$ \\
\hline $30 \%$ lodo & $60,6 a b c$ & $63,1 a b$ & $45,8 \mathrm{bcd}$ & $5,25 \mathrm{c}$ & $0,34 a$ & $2,57 \quad a$ & $1,09 \quad a$ \\
\hline
\end{tabular}

\footnotetext{
A testemunha corresponde aos tratamentos sem lodo e sem inóculo

${ }^{2}$ Doses de lodo de esgoto (\% v/v) da mistura solo - areia -lodo, tratamentos com $30 \mathrm{~g}$ de inóculo por vaso.

${ }_{3}^{3}$ expressada em $\mu \mathrm{g}$ de FDA hidrolisado.g solo $\mathrm{seco}^{-1} \cdot \mathrm{min}^{-1}{ }_{4}^{4}$ expressada em mg de $\mathrm{CO}_{2} . \mathrm{g}$ solo seco ${ }^{-1}$

${ }^{5}$ Dados seguidos da mesma letra na coluna não diferem significativamente (Teste de Duncan, ao nível de $5 \%$ de probabilidade)
} 
A recuperação do patógeno das raízes das mudas e da mistura solo areia - lodo não apresentou uma tendência definida, com valores baixos como no experimento anterior. No caso da recuperação da $P$. nicotianae das raízes, os coeficientes de variação foram altos, e não se estabeleceram diferenças estatisticamente significativas entre tratamentos, Já na recuperação do patógeno do solo - areia - lodo de esgoto, foram observadas diferenças significativas (Tabela 9).

Nesse experimento, diferentemente do anterior, não foram observadas correlações significativas entre recuperação do patógeno e atividade microbiana do solo, nem entre recuperação do patógeno e condutividade elétrica.

Tabela 9. Efeito do lodo de esgoto na recuperação de Phytophthora nicotianae das raízes das mudas de limão cravo (Citrus lemonia) e do solo - areia todo de esgoto, mediante o teste de iscas de folhas de citros, aos 120 dias após o transplante, no experimento 2 .

\begin{tabular}{ccccc}
\hline Tratamento & \multicolumn{2}{c}{ Raízes (\%) $^{3}$} & \multicolumn{2}{c}{ Solo - areia - lodo (\%) ${ }^{3}$} \\
\hline Testemunha $^{1}$ & 0,0 & n.s. & $0,5^{4}$ & $\mathrm{c}$ \\
0\% lodo $^{2}$ & 6,0 & n.s. & 4,0 & $\mathrm{abc}$ \\
$\mathbf{5 \%}$ lodo & 4,0 & n.s. & 3,5 & $\mathrm{abc}$ \\
$\mathbf{7 , 5 \% \text { lodo }}$ & 0,5 & n.s. & 7,2 & $\mathrm{ab}$ \\
$\mathbf{1 0 \%}$ lodo & 1,0 & n.s. & 9,0 & $\mathrm{a}$ \\
$\mathbf{1 5 \%}$ lodo & 5,0 & n.s. & 1,5 & $\mathrm{bc}$ \\
$\mathbf{2 0 \%}$ lodo & 9,0 & n.s. & 7,0 & $\mathrm{ab}$ \\
$\mathbf{3 0 \%}$ lodo & 1,0 & n.s. & 5,6 & $\mathrm{abc}$
\end{tabular}

\footnotetext{
${ }^{1}$ A testemunha corresponde aos tratamentos sem lodo e sem inóculo

${ }^{2}$ Doses de lodo de esgoto (\% v/v) da mistura solo - areia -lodo, tratamentos com $30 \mathrm{~g}$ de inóculo por vaso.

${ }^{3}$ Para a análise estatística, os dados da porcentagem de recuperação do patógeno do solo e das raízes foram transformados em arco seno $\sqrt{ } \mathrm{x} / 100$.

${ }^{4}$. Dados seguidos da mesma letra na coluna não diferem significativamente (Teste de Duncan, ao nível de $5 \%$ de probabilidade); n.s.= não significativo.
} 


\subsection{Efeito do lodo de esgoto na indução de supressividade a $P$. nicotianae em mudas de limão cravo no campo}

Para as variáveis altura, peso da matéria fresca da parte aérea e das raízes da mudas foram observadas diferenças estatisticamente significativas entre os tratamentos nas diferentes datas de avaliação. Essas diferenças foram devido aos fatores lodo e blocos para as variáveis altura e peso da matéria fresca das mudas. Entretanto para o peso da matéria fresca das raízes só houve efeito do fator blocos. Embora nem sempre fossem observadas diferenças estatisticamente significativas, as tendências das variáveis mostraram uma resposta positiva ao incremento dos níveis de lodo de esgoto. Como não houve efeito significativo do fator níveis de inóculo, foram obtidas médias dos tratamentos com e sem inóculo, apresentadas na Figura 9.

Os valores de condutividade elétrica e pH em água da solução do solo lodo de esgoto apresentaram diferenças estatisticamente significativas entre os tratamentos, explicadas pelo fator lodo para a condutividade elétrica, e pelos fatores lodo e blocos para o pH, nas diferentes datas de avaliação. Como não houve efeito significativo do fator níveis de inóculo, foram obtidas médias dos tratamentos com e sem inóculo (Figura 10).

Os valores da condutiviade elétrica aumentaram até os 43 dat (ou 45 dias após incorporação do lodo de esgoto ao solo), e logo após decresceram, com uma tendência a se estabilizar a partir dos 118 dat, mas sempre com valores superiores aos iniciais. Pode-se observar que em geral, os valores da condutiviade elétrica aumentaram com o incremento dos níveis de lodo de esgoto, e só os tratamentos com adubação mineral superaram os com lodo a partir dos 118 dat.

Para o $\mathrm{pH}$, os tratamentos sem lodo e sem adubo mineral apresentaram os maiores valores e com uma tendência estável ao longo do experimento. Os tratamentos sem lodo e com adubo foram estáveis até 43 dat, e daí decresceram até os 182 dat, atingindo junto aos tratamentos com $15 \%$ de lodo, os menores valores do experimento. De modo geral, houve uma tendência de redução do $\mathrm{pH}$ com o aumento dos níveis de lodo no solo (Figura 10). 

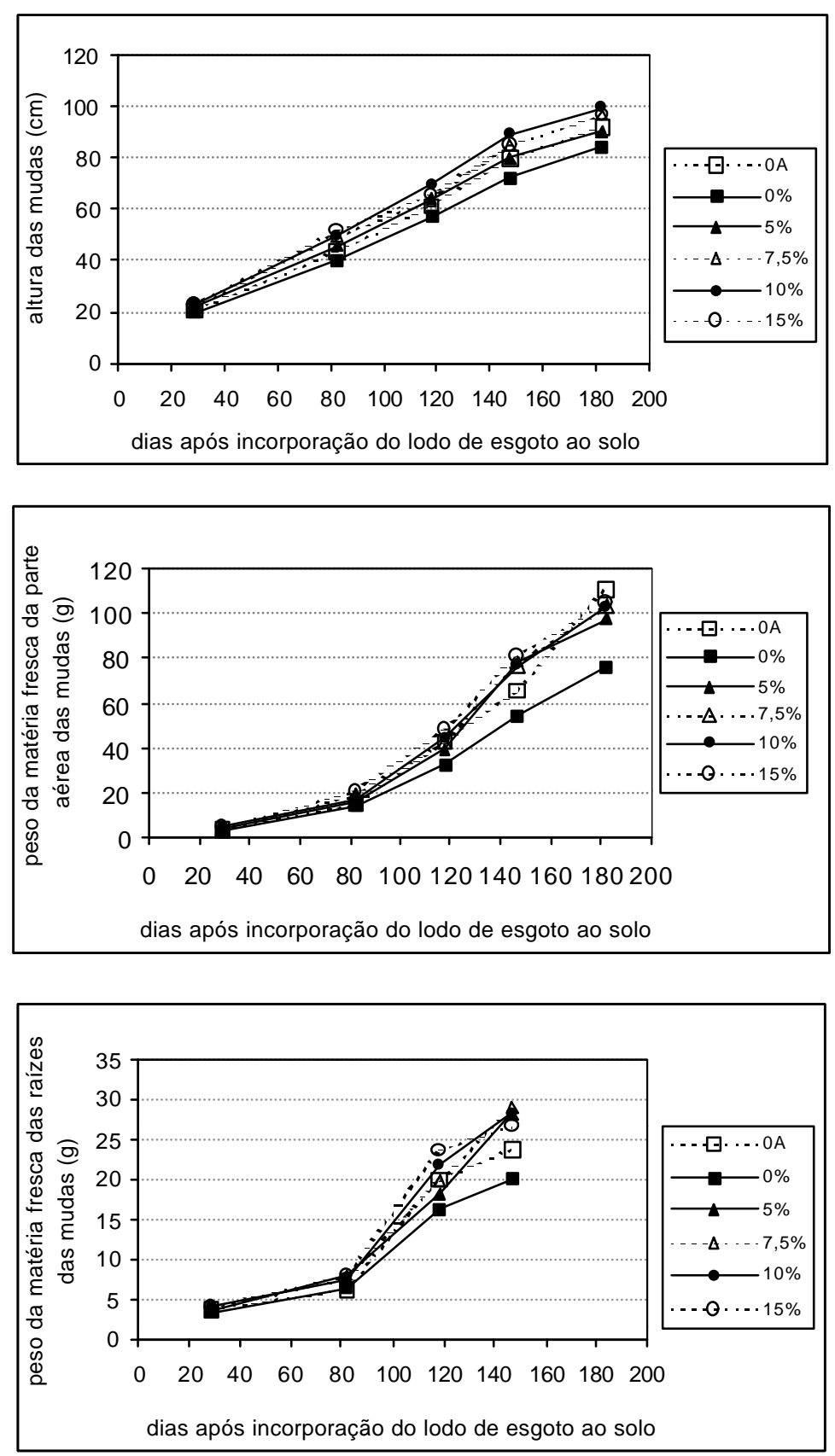

Figura 9- Evolução da altura, peso da matéria fresca da parte aérea e das raízes das mudas de limão cravo (Citrus lemonia), nos diferentes tratamentos de solo sem lodo e com adubo mineral (OA) ou com incorporação de lodo nas proporções de $0 ; 5 ; 7,5 ; 10$ e $15 \%$ v/v, no experimento de campo (média dos tratamentos com e sem inóculo). 

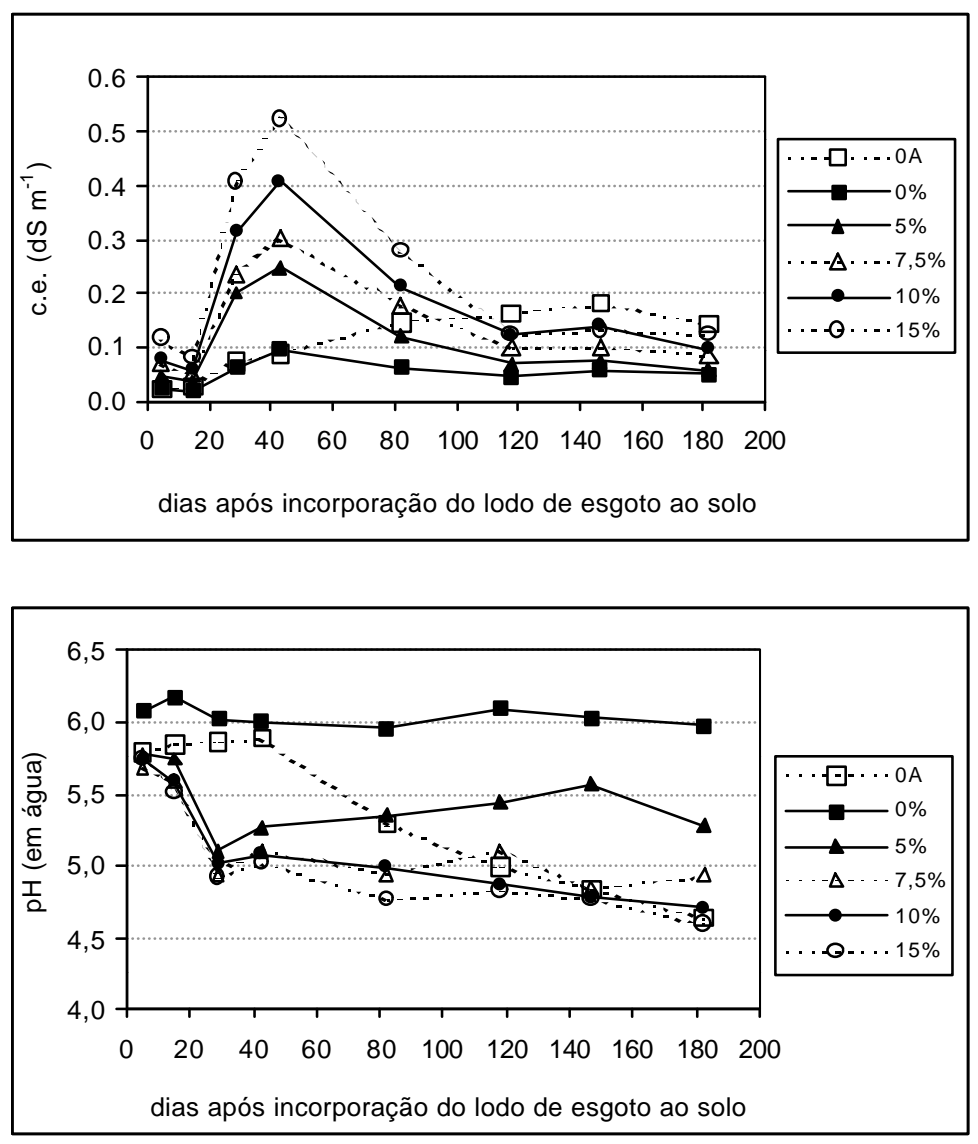

Figura 10- Evolução da condutividade elétrica (c.e.) e pH em água da solução do solo, nos diferentes tratamentos de solo sem lodo e com adubo mineral (OA) ou com incorporação de lodo nas proporções de $0 ; 5 ; 7,5 ; 10$ e $15 \% \mathrm{v} / \mathrm{v}$, no experimento de campo (média dos tratamentos com e sem inóculo). 
No geral, os resultados da análise do tecido foliar das mudas mostraram que as diferenças entre os tratamentos com e sem lodo são pequenas. $O$ tratamento sem lodo e sem adubação mineral diferenciou-se dos outros por ser o único com valores de nitrogênio $(\mathrm{N})$ considerados ótimos e de potássio $(K)$, altos. Para os outros nutrientes, todos os tratamentos apresentaram valores de fósforo $(\mathrm{P})$ considerados altos, de magnésio $(\mathrm{Mg})$ e ferro $(\mathrm{Fe})$, ótimos; e de cálcio $(\mathrm{Ca})$, boro $(\mathrm{B})$, cobre $(\mathrm{Cu})$ e zinco (Zn), baixos (Tabela 10).

Tabela 10. Efeito do lodo de esgoto na composição do tecido foliar das mudas de limão cravo (Citrus lemonia) aos 182 dias após o transplante, do experimento no campo.

\begin{tabular}{|c|c|c|c|c|c|c|c|c|c|c|}
\hline Tratamento & $\begin{array}{c}\mathbf{N} \\
\mathrm{g} \mathrm{kg}^{-1}\end{array}$ & $\begin{array}{c}\mathbf{K} \\
\mathrm{g} \mathrm{kg}^{-1}\end{array}$ & $\begin{array}{c}\mathbf{P} \\
\mathrm{g} \mathrm{kg}^{-1}\end{array}$ & $\begin{array}{c}\mathbf{C a} \\
\mathrm{g} \mathrm{kg}^{-1}\end{array}$ & $\begin{array}{c}\text { Mg } \\
g^{k^{-1}}\end{array}$ & $\begin{array}{c}\text { B } \\
\mathrm{mg} \mathrm{kg}^{-1}\end{array}$ & $\begin{array}{c}\mathbf{C u} \\
\mathrm{mg} \mathrm{g}^{-1}\end{array}$ & $\begin{array}{c}\mathbf{F e} \\
\mathrm{mg} \mathrm{kg}^{-1}\end{array}$ & $\begin{array}{c}\text { Mn } \\
\mathrm{mg} \mathrm{kg}^{-1}\end{array}$ & $\begin{array}{c}\mathbf{Z n} \\
\mathrm{mg} \mathrm{kg}^{-1}\end{array}$ \\
\hline & \multicolumn{10}{|c|}{ Tratamentos sem inoculação com Phytophthora nicotianae } \\
\hline $0 \%$ lodo $^{1}$ & $25,5^{3}$ & 12,4 & 1,7 & 20,9 & 2,1 & 18,6 & 3,6 & 96 & 24 & 15,4 \\
\hline $0 \%+A^{2}$ & 27,6 & 9,4 & 1,6 & 20,0 & 2,4 & 16,4 & 4,1 & 85 & 22 & 15,2 \\
\hline $5 \%$ lodo & 27,0 & 9,9 & 1,7 & 20,2 & 2,3 & 15,4 & 4,9 & 86 & 22 & 16,8 \\
\hline $7,5 \%$ lodo & 26,5 & 9,4 & 1,8 & 21,9 & 2,3 & 18,2 & 4,9 & 88 & 34 & 16,5 \\
\hline $10 \%$ lodo & 27,2 & 9,9 & 1,7 & 19,8 & 2,2 & 15,3 & 4,9 & 76 & 29 & 16,1 \\
\hline \multirow[t]{2}{*}{$15 \%$ lodo } & 27,5 & 9,4 & 2,0 & 28,2 & 2,7 & 16,0 & 4,8 & 83 & 27 & 16 \\
\hline & \multicolumn{10}{|c|}{ Tratamentos com inoculação com Phytophthora nicotianae } \\
\hline $0 \%$ lodo & 25,2 & 9,9 & 1,7 & 20,4 & 2,3 & 18,9 & 3,2 & 87 & 17 & 15,1 \\
\hline $0 \%+A$ & 27,7 & 10,4 & 1,5 & 18,2 & 2,3 & 13,9 & 5,2 & 74 & 20 & 16,7 \\
\hline $5 \%$ lodo & 25,5 & 9,9 & 1,7 & 22,3 & 2,3 & 15,3 & 4,9 & 96 & 23 & 17,7 \\
\hline $7,5 \%$ lodo & 26,5 & 9,9 & 1,8 & 19,3 & 2,1 & 18,7 & 4,9 & 79 & 23 & 16,9 \\
\hline $10 \%$ lodo & 27,2 & 9,4 & 1,9 & 23,0 & 2,3 & 18,5 & 5,4 & 81 & 23 & 16,8 \\
\hline \multirow[t]{2}{*}{$15 \%$ lodo } & 27,4 & 10,4 & 2,0 & 24,3 & 2,2 & 17,9 & 5,4 & 95 & 29 & 20,7 \\
\hline & \multicolumn{10}{|c|}{ Valores de referência } \\
\hline BAIXO ${ }^{4}$ & $<23,9$ & $<6,9$ & $<1,1$ & $<29$ & $<1,9$ & $<30$ & $<5$ & $<59$ & $<24$ & $<24$ \\
\hline ÓTIMO & $24-26$ & $7-10,9$ & $1,2-1,6$ & $30-55$ & $2-3$ & $31-100$ & $6-16$ & $60-120$ & $25-200$ & $25-100$ \\
\hline ALTO & $>27$ & $>11$ & $>1,7$ & $>56$ & $>4$ & $>101$ & $>17$ & $>121$ & $>300$ & $>110$ \\
\hline
\end{tabular}


A atividade microbiana do solo, avaliada pela hidrólise de FDA e respiração microbiana (desprendimento de $\mathrm{CO}_{2}$ ), mostrou diferenças estatisticamente significativas entre tratamentos nas diferentes datas de avaliação. Essas diferenças foram devidas aos fatores lodo e bloco para a variável hidrólise de FDA, e lodo para a respiração, com respostas positivas ao incremento dos níveis de lodo de esgoto. Como ocorreu com as outras variáveis, o fator inóculo não foi significativo para nenhuma das datas de avaliação. A evolução da atividade microbiana no tempo apresentou máximos de atividade aos 5 e 15 dias para desprendimento de $\mathrm{CO}_{2}$ e hidrólise de FDA, respectivamente (Figura 11).
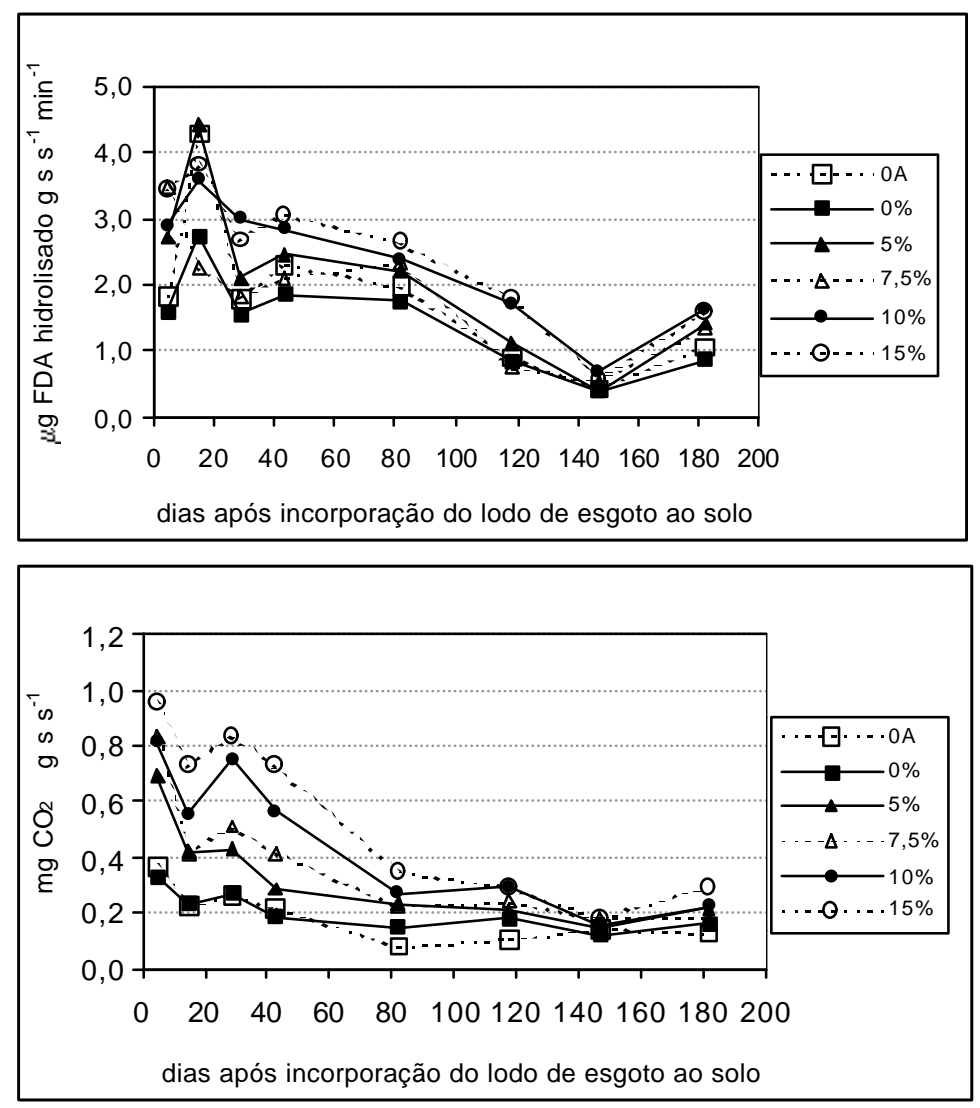

Figura 11- Evolução da atividade microbiana do solo avaliada pela hidrólise de diacetato de fluoresceina (FDA) e respiração microbiana (desprendimento de $\mathrm{CO}_{2}$ ), nos diferentes tratamentos de solo sem lodo e com adubo mineral (0A) ou com incorporação de lodo nas proporções de 0; 5; 7,5; 10 e $15 \%$ $\mathrm{v} / \mathrm{v}$, no experimento de campo (média dos tratamentos com e sem inóculo). 
A recuperação de $P$. nicotianae do solo só foi possível aos 82 dias após transplante das mudas, com valores baixos, mas que mostraram uma tendência a diminuir quando os valores de lodo de esgoto aumentaram (Tabela 11). Nas outras datas, não houve recuperação do patógeno, tanto das raízes quanto do solo. Os valores de recuperação do patógeno do solo correlacionaram-se com os valores da hidrólise de FDA ( $r=-0,2819 ; P=0,052)$, mas não com os da respiração microbiana, nem com a condutiviadade elétrica e pH do solo.

Tabela 11. Efeito do inóculo e do lodo de esgoto na recuperação de Phytophthora nicotianae do solo mediante teste de isca de folhas de citros aos 82 dias após o transplante, nas parcelas do experimento no campo.

\begin{tabular}{cl}
\hline Fator & médias \\
\hline $\begin{array}{c}\text { níveis de inóculo } \\
0 \mathrm{~g}\end{array}$ & $0,00 \mathrm{~b}^{2,3}$ \\
$20 \mathrm{~g}$ & $2,56 \mathrm{a}$ \\
$\begin{array}{c}\text { doses de lodo } \\
0 \% \text { lodo }+ \text { adubo mineral }\end{array}$ & $2,19 \mathrm{n} . \mathrm{s}$ \\
$0 \%$ de lodo & $4,19 \mathrm{n} . \mathrm{s}$ \\
$5 \%$ de lodo & 0,69 n.s \\
$7,5 \%$ de lodo & 0,31 n.s \\
$10 \%$ de lodo & 0,31 n.s \\
$15 \%$ de lodo & 0,00 n.s \\
\hline
\end{tabular}

${ }_{2}^{1}$ Porcentagens de lodo incorporadas ao solo ( $\left.\mathrm{v} / \mathrm{v} \%\right)$

${ }^{2}$ Para a análise estatística, os dados da porcentagem de recuperação do patógeno do solo foram transformados em arco seno $\sqrt{ } \mathrm{x} / 100$.

${ }^{3}$ Dados seguidos da mesma letra, na coluna, não diferem significativamente ao nível de $5 \%$ de probabilidade 


\subsection{Isolamento e seleção de antagonistas a P. nicotianae.}

O número médio de colônias isoladas do solo das parcelas do experimento no campo foi da ordem de $10^{6}, 10^{5}$ e $10^{4}$ colônias por grama de solo para bactérias, actinomicetos e fungos, respectivamente. Quando analisados os dados, os tratamentos com e sem lodo tiveram em média valores semelhantes para os diferentes grupos de microrganismos isolados (Figura 12).
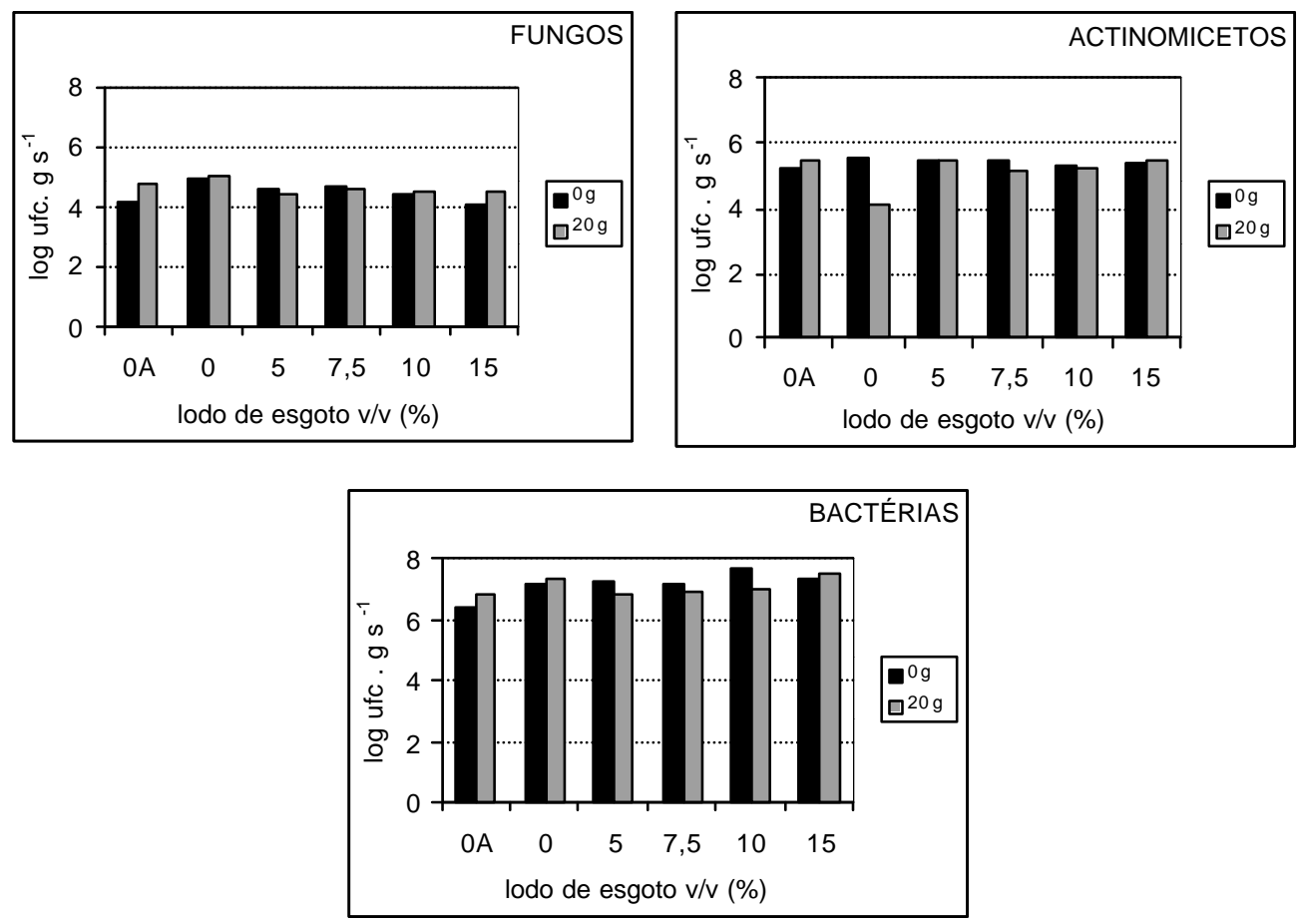

Figura 12- Comunidades de fungos, actinomicetos e bactérias (unidades formadoras de colônias - ufc) isoladas do solo do experimento do campo, com 0 ou $20 \mathrm{~g}$ de inóculo por muda, aos 28 dias após o transplante, nos diferentes tratamentos de solo sem lodo e com adubo mineral (OA), ou com incorporação de lodo nas proporções de 0; 5; 7,5; 10 e 15\% v/v. 
No bioensaio, foram testadas quanto a sua potencialidade como antagonista a $P$. nicotianae, 35 colônias de bactérias, 32 de actinomicetos e 52 de fungos. Dos isolados testados, só um fungo (isolado F9.1, do gênero Aspergillus; obtido das parcelas com adubo mineral e inoculadas com $P$. nicotianae) e um actinomiceto (isolado A12.1, sem identificar; obtido das parcelas com $15 \%$ de lodo e inoculada) tiveram um controle total da $P$. nicotianae, ou seja, um comportamento semelhante à testemunha com água destilada esterilizada onde as plântulas de alfafa não apresentaram nem zoosporângios nem micélio. Sete isolados de fungos, três de actinomicetes e dois de bactérias permitiram o desenvolvimento de micélio, mas não dos zoosporângios (Tabela 12). Alguns isolados tiveram um comportamento semelhante àtestemunha com água e $P$. nicotianae.

Dos isolados que se destacaram no bioensaio, quando testados em meio de cultura (teste de pareamento de colônias), destacaram-se quatro fungos, dois actinomicetos, mas nenhuma bactéria. Um fungo do gênero Trichoderma (isolado F8.3/4; obtido das parcelas com adubo mineral e inoculada) destacou-se por antibiose com formação de halo de inibição de $1 \mathrm{~cm}$; e os outros três, um Trichoderma (isolado F12.3; obtido das parcelas com $15 \%$ de lodo e inoculada) e dois Aspergillus (isolados F9.1, F11.1; obtidos das parcelas com 5 e $10 \%$ de lodo e inoculadas, respectivamente) por hiperparasitismo, com crescimento micelial recobrindo toda a placa em $72 \mathrm{~h}$. Os dois actinomicetos (isolados A2.1 e A12.1; obtido das parcelas com adubo mineral e sem inóculo e com $15 \%$ de lodo e inoculada, respectivamente) também desenvolveram halos de inibição de $1 \mathrm{~cm}$. 
Tabela 12. Efeito de alguns isolados de fungos, actinomicetos e bactérias, testados quanto a potencialidade como antagonistas a Phytophthora nicotianae, na infestação de plântulas de alfafa (Medicago sativa L.).

\begin{tabular}{|c|c|c|c|}
\hline & \multicolumn{3}{|c|}{ Isolados } \\
\hline & Fungos & Actinomicetos & Bactérias \\
\hline$Z=0$ e $M=0^{1,2}$ & $\mathrm{~F} 9.1^{3}$ & $\mathrm{~A} 12.1$ & ----- \\
\hline$Z=0$ & $\begin{array}{c}F 9.1, F 11.1, F 10.4, \\
F 10.8, F 8.3 / 4, \\
F 12.3, F 8.10\end{array}$ & $\mathrm{~A} 12.1, \mathrm{~A} 9.7, \mathrm{~A} 2.1$ & B11.1, B10.6 \\
\hline $\begin{array}{c}Z<0,75 \text { e } \\
M<1,0\end{array}$ & $\begin{array}{c}\text { F9.1, F10.4, F4.1, } \\
\text { F2.1, F8.10, F7.1, } \\
\text { F10.1, F8.3/2 }\end{array}$ & $\begin{array}{c}\text { A12.1, A3.2, A4.2, } \\
\text { A6.6, A4.1b, A6.1, } \\
\text { A9.7, A2.1, A6.5, } \\
\text { A6.4 }\end{array}$ & $\begin{array}{l}\mathrm{B} 11.5, \mathrm{~B} 11.1, \\
\mathrm{~B} 11.3, \mathrm{~B} 10.10\end{array}$ \\
\hline$z>3,0$ & $\begin{array}{c}F 5.3, F 2.2, F 3.5 \\
F 10.5, F 4.7, F 10.9 \\
\text { F4.4, F10.3 }\end{array}$ & A3.1, A9.6 & $\begin{array}{c}\text { B10.2, B10.3, } \\
\text { B11.2, B1.6, } \\
\text { B10.11,B11.4, } \\
\text { B11.8, B11.6, } \\
\text { B1.10, B1.1, B1.13, } \\
\text { B10.4, B10.1, } \\
\text { B10.12, B1.8, B1.5, } \\
\text { B10.9 }\end{array}$ \\
\hline
\end{tabular}

${ }^{1} \mathrm{Z}=\mathrm{N}^{\circ}$ de zoosporângios por plântula, $0=$ sem zoosporângios, $1=1$ a 5; $2=6$ a 10; $3=11$ a $50,4=>51 ; M=$ presença de micélio de Phytophthora nicotianae nas plântulas, $0=$ sem micélio, 1 = pouco, $2=$ médio, $3=$ muito.

${ }^{2}$ médias de 4 repetições

3 A primeira letra do nome do isolado corresponde ao grupo de microrganismo ( $F$ : fungos, $A$ : actinomicetos e $\mathrm{B}$ : bactérias). O primeiro número do nome do isolado corresponde ao tratamento: $1=$ parcelas sem lodo e sem inóculo de Phytophthora nicotianae, $2=\mathrm{com}$ adubo mineral e sem inóculo, $3=$ com $5 \%$ de lodo e sem inóculo, $4=$ com $7,5 \%$ de lodo e sem inóculo, $5=$ com $10 \%$ de lodo e sem inóculo, $6=$ com $15 \%$ de lodo e sem inóculo, $7=$ sem lodo e com inóculo, $8=$ com adubo mineral e com inóculo, $9=$ com $5 \%$ de lodo e com inóculo, 10= com 7,5\% de lodo e com inóculo, $11=$ com $10 \%$ de lodo e com inóculo, $12=$ com $15 \%$ de lodo e com inóculo. 


\section{$5 \quad$ DISCUSSÃO}

\subsection{Efeito do lodo de esgoto sobre o pH e a condutividade elétrica do solo.}

Nos diferentes experimentos (in vitro, em casa de vegetação e no campo), os valores de $\mathrm{pH}$ mostraram uma tendência de diminuir quando os níveis de lodo de esgoto aumentaram (Figuras 2, 4, 7 e 10, e Tabela 8). Esse fato também foi observado por Carmo (2001) e Schoenmaker (2000) quando lodo de esgoto não calado foi incorporado ao solo. Já Carmo (2001), Costa et al.(1996), Fortes Neto (2000) e Melo \& Marques (2000) verificaram efeito contrário quando utilizaram lodo calado.

Segundo Carmo (2001), a diminuição dos valores de pH na solução do solo deve-se à liberação de $\mathrm{N}-\mathrm{NH}_{4}{ }^{+}$durante o processo de mineralização do lodo no solo, e os altos teores de $\mathrm{NH}_{4}{ }^{+}$podem indicar uma maior liberação de $\mathrm{H}^{+}$para o meio promovendo acidificação. Oliveira (2000), revisando vários trabalhos, cita também como causa da acidificação do solo a provável oxidação de sulfitos e a produção de ácidos orgânicos durante a degradação do resíduo.

Os valores de $\mathrm{pH}$ obtidos no presente trabalho estão dentro dos limites superiores de tolerância definidos pela US EPA - 40CFR e adotado pela CETESB $\mathrm{P} 4230$, que estabelece que o pH do solo não deve superar o valor de 6,5 (Andreoli \& Pegorini, 2000; Berton, 2000). Mas a tendência desses valores de $\mathrm{pH}$ a diminuir até valores que incidam negativamente no desenvolvimento das plantas deve ser avaliado, para definir as quantidades de lodo e intervalos de aplicação permitidos.

A condutividade elétrica (c.e.) nos diferentes experimentos realizados aumentou como resposta ao incremento nas quantidades de lodo incorporadas tanto 
ao substrato quanto ao solo (Figuras 2, 4, 7 e 10, e Tabela 8), o que coincide com os dados reportados por Carmo (2001) e Oliveira (2000). Os valores de c.e. obtidos não atingiram os níveis de $2 \mathrm{dS} \mathrm{m}^{-1}$ que caraterizam os solos salinos, nem os valores máximos de 3,5 dS $\mathrm{m}^{-1}$ recomendados para o uso agrícola dos solos na Flórida, Estados Unidos (Widmer et al., 1998). Porém, os valores de c.e. não afetaram negativamente o desenvolvimento das mudas de citros (Figuras 3, 6 e 9, e Tabela 8), como também foi observado por Lapeña et al. (2000) que não observaram danos em plântulas de diferentes porta - enxertos de citros crescendo sob c.e. de 1; 3,5 e 5 dS $\mathrm{m}^{-1}$ por $24 \mathrm{~h}$.

Apesar dos resultados obtidos, é importante destacar que a possibilidade de salinização dos solos, devido a utilização pouco cuidadosa do lodo de esgoto, é real. Dessa forma, é imprescindível que esta variável seja monitorada e considerada em estratégias de manejo (Oliveira, 2000).

\subsection{Efeito do lodo de esgoto no desenvolvimento das plântulas e das mudas.}

Em todos os experimentos realizados, de modo geral, o lodo apresentou um efeito significativo e positivo no desenvolvimento das mudas, com comportamentos iguais ou superiores às testemunhas com adubação mineral (Figuras 3, 6 e 9, e Tabela 8). Esses resultados estão de acordo com a bibliografia que sugere melhores desenvolvimentos das plantas crescendo em solos com incorporação de matéria orgânica de diversos origens (Bettiol \& Krügner, 1984; Kim et al., 1997; Pascual et al., 2000).

Com a incorporação de lodo de esgoto em concentrações de $30 \% \mathrm{v} / \mathrm{v}$ em base fresca, tanto nos experimentos com plântulas e com mudas em casa de vegetação, observou-se uma tendência de decréscimo na altura e peso da matéria fresca da parte aérea e raízes (Figuras 3 e 6), sugerindo um possível efeito de fitotoxidez como reportado por outros autores quando grandes volumes de matéria orgânica são incorporados ao solo e/ou quando estes não estão bem compostados (Aryantha et al., 2000; Casale et al., 1995; De Vleeschauwer et al., 1981; Widmer et al., 
1998). Segundo Widmer et al. (1998), esse efeito negativo pode desaparecer com o passar do tempo, e num prazo maior estimular o desenvolvimento da cultura. De Vleeschauwer et al. (1981) estudaram os componentes fitotóxicos de compostos de lixo urbano fresco, e determinaram que a principal substância fitotóxica foi o ácido acético, seguido de ácidos orgânicos (propiônico, isobitírico, butírico e isovalérico), os quais atingiram níveis não tóxicos às plantas após 5 meses de compostagem.

É importante que, embora os experimentos com incorporação de lodo em $30 \% \mathrm{v} / \mathrm{v}$ em base fresca fossem em tubetes ou vasos, esses níveis superam amplamente os valores máximos de incorporação ao solo admitidos pelas normas, especialmente quanto ao nitrogênio incorporado. No estado de Paraná, os critérios para a definição das taxas de aplicação do lodo com fins agrícolas estabelece que as doses de lodo de esgoto a serem aplicadas estão determinadas, entre outros, pelo aporte de nitrogênio necessário para o desenvolvimento da cultura; e pode se aplicar um máximo de 50 toneladas de lodo em base seca em 10 anos e a quantidade de metais pesados adicionados não pode exceder o nível máximo permitido (Andreoli \& Pegorini, 2000). Esses valores definidos pelas normas principalmente visam a não contaminação do solo com metais pesados e dos lençóis freáticos com nitratos, e como aponta Oliveira (2000), a lixiviação de $\mathrm{N}-\mathrm{NO}_{3}$ deve ser o fator mais restritivo na definição das taxas e freqüência de aplicação do lodo de esgoto a mediano prazo, pelos riscos existentes. Mas, além dos riscos de contaminação, os excessos de nitrogênio e desequilíbrios de nutrientes podem causar problemas no desenvolvimento das culturas.

Quando analisados os dados da composição química do tecido foliar das mudas, observam-se resultados variáveis dependendo do experimento e do nutriente. Isto estaria indicando a necessidade de novos experimentos e as limitações de comparar os dados dos experimentos realizados em vasos e em campo, quando avalia-se a dinâmica dos nutrientes provenientes de fontes de matéria orgânica.

Nos dois experimentos observou-se um possível efeito compensador do lodo para o potássio $(\mathrm{K})$ onde os tratamentos sem lodo tiveram excesso desse nutriente. Este fato pode-se explicar pois em geral o lodo de esgoto é deficiente em $\mathrm{K}$, 
mineral altamente solúvel em água, e durante o processo de tratamento de esgoto, o potássio fica contido no efluente líquido (Tomoyuki, 2000). Já para o fósforo (P) os valores sempre foram altos, e para o nitrogênio $(\mathrm{N})$ e os outros nutrientes os efeitos foram variáveis (Tabelas 5 e 10). Os níveis de $\mathrm{N}$ nas folhas das mudas do campo foram apenas superiores aos valores ótimos, independentemente das quantidades de lodo incorporadas ao solo (27\% a menos e 9, 46 e 119\% superiores æ̀s necessárias para os tratamentos com 5; 7.5; 10 e $15 \% \mathrm{v} / \mathrm{v}$ de lodo, respectivamente), possivelmente devido a uma mineralização do lodo menor que a esperada como conseqüência da estiagem ocorrida durante o experimento (dezembro 2000 - julho 2001) e a pobre irrigação recebida.

\subsection{Efeito do lodo de esgoto na indução de supressividade a $\boldsymbol{P}$. nicotianae.}

A supressividade a Phytophthora nicotianae foi diretamente proporcional àconcentração de lodo de esgoto incorporado no solo e no substrato (Figuras 1, 5 e 8; e Tabelas 9 e 11). Esses resultados são coincidentes com os obtidos por outros autores, tanto para o manejo das doenças causadas por Phytophthora como por outros patógenos, em diversas culturas (Baker \& Cook, 1974; Bettiol \& Krügner, 1984; Casale et al., 1995; Chung et al.; 1988; Costa et al.,1996; Erwin \& Ribeiro, 1996; Feichtenberger et al., 1997; Hoitink \& Boehm, 1999; Kim et al.; 1997; Lewis et al., 1992; Lumsden et al., 1983; Millner et al., 1981; Pereira et al., 1996; Schoemaker \& Ghini, 1999; Widmer et al., 1998).

Dentre os fatores que podem explicar a supressividade a $P$. nicotianae, a presença de compostos tóxicos devido aos processos de decomposição da matéria orgânica adicionada ao solo é uma delas. Esses efeitos têm sido reportados por vários autores para diversos patógenos, usando diferentes fontes de matéria orgânica (Blok et al., 2000; Casale et al., 1995; Gamliel et al., 2000; Hoitink et al., 1977; Pereira et al., 1996). No presente trabalho, foram obtidas inibições do crescimento in vitro de colônias do patógeno quando colocado para crescer em meio de cultura acrescentado com extratos ácidos (Tabela 4), como também foi obtido por Widmer et al. (1998), sugerindo um possível efeito químico na indução de supressividade. 
Um segundo fator que pode explicar a supressividade a $P$. nicotianae são os valores de condutividade elétrica (c.e.) obtidos quando o lodo de esgoto foi incorporado ao solo ou substrato (Figuras 2, 4, 7 e 10, e Tabela 8). Lapeña et al. (2000) observaram que sob condutividade elétrica de até $5 \mathrm{dS} \mathrm{m}^{-1}$ por $24 \mathrm{~h}$, a viabilidade, e porém a capacidade de infectar, dos zoosporângios de Phytophthora citrophthora diminui. Workneh et al. (1993) estabeleceram correlações negativas entre condutividade elétrica e presença de $P$. parasitica ou incidência da doença em plantas de tomateiro.

Um terceiro fator que pode explicar a supressividade a $P$. nicotianae é a melhora das propriedades físicas e químicas do solo, resultando num melhor desenvolvimento das plântulas e mudas. São conhecidos os efeitos benéficos da adição de matéria orgânica ao solo na melhoria da infiltração e drenagem do solo, favorecendo o desenvolvimento radicular e limitando a possibilidade de saturação do solo por excessos de água. Também, a incorporação de matéria orgânica ao solo contribui para uma nutrição mais equilibrada das plantas, compensando desbalanços.

Um quarto fator que pode explicar a supressividade a $P$. nicotianae, citado por vários autores como um dos principais, é o aumento da atividade microbiana do solo. Essas populações microbianas estabeleceriam um controle biológico mediante os mecanismos clássicos descritos por Baker \& Cook (1974): competição, antibiose, parasitismo e indução de resistência. O sucesso do controle da Phytophthora pela comunidade microbiana baseia-se, entre outros, em sua baixa capacidade saprofítica e competitiva (Erwin \& Ribeiro, 1996). Malacjzuck (1983) sugere que os principais mecanismos envolvidos no controle de Phytophthora são competição por nutrientes e antibiose.

O aumento da atividade microbiana do solo foi constatado no presente trabalho, com respostas positivas da hidrólise de diacetato de fluoresceina (FDA) e respiração microbiana à incorporação de lodo de esgoto ao solo (Tabelas 6 e 8, e Figura 11). Esses dados são coincidentes com os resultados de vários autores que reportaram correlações significativas entre incidência da doença ou presença dos 
patógenos e aumento nos valores de FDA (Aryantha et al., 2000; Boehm \& Hoitink, 1992; Costa et al.,1996; Downer et al., 2001b; Ghini et al., 1998; Kim et al., 1997; Workneh et al., 1993). Outras medidas da atividade microbiana e sua relação com a supressividade aos patógenos foram demonstradas por diversos autores: desprendimento de $\mathrm{CO}_{2}$ (Costa et al., 1996; Ghini et al., 1998); atividade da deshidrogenase (Lewis et al., 1992) e outras enzimas como fosfatase, urease, $\beta$ glucosidase, galactosidase, N-acetil-glucosa-aminidase (Pascual et al., 2000); e tamanho da biomassa microbiana (Hoitink \& Boehm, 1999). Hoitink \& Boehm (1999) sugerem que o nível de hidrólise de FDA é um bom indicador da supressividade dos solos, mas consideram que o sucesso do controle biológico de Pythium e Phytophthora também depende da quantidade e qualidade da matéria orgânica que ofereça energia aos microrganismos envolvidos no controle biológico.

Devido à complexidade dos processos envolvidos, para determinar o impacto potencial da incorporação de matéria orgânica ao solo na indução de supressividade aos diferentes patógenos, são necessários estudos locais, nos solos e com as fontes de matéria orgânica disponíveis na região. No caso da supressividade a Phytophthora é importante a atividade celulolítica dos microrganismos envolvidos, considerando que as paredes dos chromistas estão constituídas principalmente por celulose ( $\beta-1,4$ glucanos) e $\beta-1,3$ e $\beta-1,6$ glucanos (Bartnicki - Garcia \& Wang, 1983). Assim, trabalhos futuros visando estudar os fatores envolvidos na supressividade a Phytophthora poderiam incluir a análise de atividade celulolítica dos microrganismos do solo, além das técnicas acima descritas. Downer et al. (2001a, 2001b) sugerem que a produção de celulase e laminarinase é o principal mecanismo envolvido na supressividade a $P$. cinnamomi no sistema Ashburner, destruindo zoósporos e outros propágulos do patógeno. Esses autores afirmam que as enzimas são produzidas pela comunidade de fungos, entre eles Penicillum e Aspergillus, e que essa atividade enzimática é favorecida por valores de $\mathrm{pH}$ baixos.

A incorporação do lodo de esgoto ao solo não alterou as comunidades de fungos, actinomicetos e bactérias do solo (Figura 12), quando avaliada mediante a contagem de colônias em placas. O fato de não ter evidenciado mudanças na 
comunidade microbiana pode-se explicar em parte pela técnica empregada. No isolamento e contagem dos microrganismos mediante a técnica de diluição e plaqueamento em meio de cultura simples, estes são coletados em condições naturais e colocados a crescer em condições artificiais, favorecendo assim as espécies com rápido crescimento, e diminuindo a diversidade de espécies. Algumas vezes as mudanças em grupos microbianos específicos podem ser determinadas quando esses microrganismos podem ser cultivados in vitro. $O$ desenvolvimento de novas técnicas moleculares como a extração do DNA do solo associada a sondas adequadas para a determinação de distintos grupos funcionais e técnicas de PCR (reação em cadeia da polimerase), assim como novos estudos de ecologia microbiana, favorecerão a detecção das mudanças que ocorrem nas comunidades microbianas no solo (Lambais \& de Souza, 2000).

Lewis et al. (1992) em experimentos sob condições de campo tampouco encontraram alterações significativas nas comunidades de fungos, actinomicetos e bactérias do solo, embora o controle das doenças tenha sido eficiente. Entretanto, Millner et al. (1981) constataram o aumento das comunidades de bactérias e actinomicetos como resposta àincorporação de lodo de esgoto e Pascual et al. (2000) das comunidades de bactérias e fungos quando incorporaram composto de lixo urbano, com aumento das populações de Pseudomonas fluorescens e Trichoderma spp. Fortes Neto (2000), sob condições de campo, observou um incremento da atividade celulolítica como resposta à incorporação de lodo de esgoto ao solo, e esse aumento esteve relacionado ao aumento da respiração e biomassa microbiana, assim como com as comunidades de bactérias e amonificadores no solo. Downer et al. (2001b) obtiveram uma resposta variável dependendo do meio de cultura empregado para avaliar as comunidade microbianas dos solos com e sem "mulch", constatando mudanças nas populações de fungos saprófitas quando avaliadas em meio com Rosa de Bengala, e identificaram basidiomicetos (Phanerochaete chrysorhiza e Ceraceomyces tessulatus) crescendo sobre o "mulch" que não foram isolados em nenhum dos meios de cultura. Os solos com "mulch" tiveram uma maior diversidade de gêneros, dentre eles Penicillum, Aspergillus, Trichoderma (o qual não foi isolado dos solos sem "mulch"). 
Dentre os isolados testados no bioensaio com plântulas de alfafa para 0 controle de $P$. nicotianae, destacaram-se sete fungos, três actinomicetos e duas bactérias (Tabela 12). Dentre eles, quando enfrentados em meio de cultura (teste de pareamento de colônias), destacaram-se dois do gênero Trichoderma (um por antibiose e outro por hiperparasitismo), dois do gênero Aspergillus (por hiperparasitismo) e dois actinomicetos (ambos por antibiose), mas nenhuma bactéria. Diversas espécies do gênero Trichoderma são bem conhecidas como agentes de controle biológico de doenças causadas por Phytophthora spp. (Ahmed et al., 1999; Amorim \& Melo, 1999; Casale et al., 1995; Costa et al., 1996; Malajczuk, 1983; May, 1994; Smith et al., 1990), mas também fungos do gênero Aspergillus (Sztejnberg \& Tsao, 1986 citado por Fang \& Tsao, 1995) e actinomicetos possuem capacidade de produção de antibióticos (Malajczuk, 1983; You et al., 1996). Embora o bioensaio empregado no presente trabalho tenha mostrado capacidade na seleção de isolados, não deve-se esquecer a complexidade dos processos envolvidos no controle biológico e a necessidade de testar estes isolados em plantas e sob diferentes condições de crescimento das mesmas, assim como a sua sobrevivência no solo.

O fato de não ter sido selecionado nenhum isolado de bactéria pode-se explicar pela metodologia empregada no isolamento. O meio Nutriente - ágar (NA) é genérico para bactérias e a seleção por morfologia pode não ser a melhor opção para bactérias. Uma alternativa para melhor seleção de isolados com potencial antagônico poderia ser o emprego de meios seletivos para Pseudomonas fluorescentes e/ou para bactérias Gram negativas, que tem sido reportadas como bons antagonistas (Amorim \& Melo, 1999; Casale et al., 1995; Kim et al., 1997; Malajczuk, 1983). Uma outra opção poderia ser o emprego de iscas colonizadas com Phytophthora, para isolar microrganismos antagônicos a ela (May, 1994).

Em alguns dos experimentos, os valores de recuperação da $P$. nicotianae foram maiores quando as doses de inóculo foram menores, contrariamente ao esperado (Figuras 1, 5 e 8). Isto poderia ser explicado pelo tipo de inóculo empregado, grãos de trigo colonizados, os quais ao serem incorporados ao solo também são degradados e podem liberar substâncias tóxicas à $P$. nicotianae, incidindo negativamente em sua sobrevivência. 
Por último, vale destacar as dificuldades que se apresentaram durante o desenvolvimento do presente trabalho para a recuperação da $P$. nicotianae tanto das raízes, quanto do solo nos experimentos em casa de vegetação e no campo. Essas dificuldades podem ser explicadas tanto pela técnica de recuperação da Phytophthora, quanto pelas condições ambientais nas quais desenvolveram-se os experimentos. As altas temperaturas na casa de vegetação durante o segundo mês do estabelecimento do primeiro experimento, com mudas em vasos, podem ter afetado negativamente a esporulação e a infecção das raízes das plantas, como sugerem Matheron \& Matejka (1992). Já no campo, a baixa umidade do solo (conseqüência da estiagem durante o desenvolvimento do experimento entre fevereiro e julho de 2001) deve ter limitado a persistência do patógeno e o desenvolvimento da doença, a qual é favorecida por condições de alta umidade no solo (Erwin \& Ribeiro, 1996; Feichtenberger, 1989; Wilcox et al., 1999). Também a técnica de recuperação empregada (iscas de folhas de citros) pode ter limitado a detecção do patógeno pelo baixo número de repetições avaliadas em cada amostragem. Embora esta técnica seja bem seletiva, é muito exigente em tempo de avaliação, e a possibilidade de uso de meios de cultura seletivos deveria ser considerada. 


\section{CONCLUSÕES}

Com o aumento da dose de lodo de esgoto da ETE - Franca, incorporada ao solo, há uma redução do $\mathrm{pH}$ do solo e um incremento de sua condutividade elétrica.

O lodo de esgoto da ETE - Franca, incorporado ao solo em valores inferiores ao $20 \% \mathrm{v} / \mathrm{v}$, estimula o desenvolvimento das plântulas e mudas de limão cravo (Citrus lemonia).

A adição de lodo de esgoto da ETE - Franca favorece a indução de supressividade a Phytophthora nicotianae, devido à alterações de fatores químicos e biológicos do solo. 


\section{REFERÊNCIAS BIBLIOGRÁFICAS}

AHMED, A.S.; PEREZ-SANCHEZ, C.; EGEA, C.; CANDELA, M.E. Evaluation of Trichoderma harzianum for controlling root rot caused by Phytophthora capsici in pepper plants. Plant Pathology, v. 48, p.58-65, 1998.

AMORIM, E.P. da R.; MELO, I.S. Efeito da associação de antagonistas no controle de Phytophthora parasitica e Phytophthora citrophthora em plântulas de citros. Summa Phytopathologica, v.25, n. 4, p. 335 - 338, 1999.

ANDREOLI, C.V.; PEGORINI, E.S. Gestão pública do uso agrícola do lodo de esgoto. In: BETTIOL, W.; CAMARGO, O. A. (Ed.) Impacto ambiental do uso agrícola do lodo de esgoto. Jaguariúna: Embrapa Meio Ambiente, 2000. cap. 18, p. 281 312.

ARYANTHA, I.P.; CROSS, R.; GUEST, D.I. Suppression of Phytophthora cinnamomi in potting mixes amended with uncomposted and composted animal manures. Phytopathology, v.90, n.7, p. 775-782, 2000.

BAKER, K.F.; COOK, R.J. Biological control of plant pathogens. San Francisco: W.H. Freeman, 1974. 433p.

BARTNICKI - GARCIA, S., WANG, M. Biochemical aspects of morphogenesis in Phytophtora. In: ERWIN, D.C.; BARTNICKI - GARCIA, S., TSAO, P.H. (Ed.). Phytophthora: its biology, taxonomy, ecology and pathology. St. Paul, APS Press, 1983. cap. 9, p. $121-137$. 
BERTON, R.S. Riscos de contaminação do agroecossistema com metais pesados. In: BETTIOL, W.; CAMARGO, O. A. (Ed.) Impacto ambiental do uso agrícola do lodo de esgoto. Jaguariúna: Embrapa Meio Ambiente, 2000. cap. 16, p. 259 268.

BETTIOL, W.; CAMARGO, O.A. Impacto ambiental do uso agrícola do lodo de esgoto. Jaguariúna: EMBRAPA Meio Ambiente, 2000. 312 p.

BETTIOL, W. ; KRÜGNER, T.L. Influência do lodo de esgoto na severidade da podridão de raiz do sorgo causada por Pythium arrhenomanes. Summa Phytopathologica, v.10, p. 243 - 251, 1984.

BLOK, W.J.; LAMERS, J.G.; TERMORSHUIZEN, A.J.; BOLLEN, G.J. Control of soilborne plant pathogens by incorporating fresh organic ammendments followed by tarping. Phytopathology, v. 90, n.3, p. $253-259,2000$.

BOEHM, M. J. ; HOITINK, H. A. J. Sustenance of microbial activity in potting mixes and its impact on severity of Pythium root rot of Poinsettia. Phytopathology, v.82, n.3, p.259-264, 1992.

CAMARGO, O.A.de ; MONIZ, A.C.; JORGE, J.A.; VALADARES, J.M.A.S. Métodos de análise química, mineralógica e física de solos do Instituto Agronômico de Campinas. Campinas: Instituto Agronômico, 1986. 94 p. (IAC. Boletim Técnico, 106).

CARMO, J.B. do. Impacto da aplicação de biossólidos nas atividades microbianas do solo. Piracicaba, 2001. 105 p. Dissertação (Mestrado), Escola Superior de Agricultura “Luiz de Queiroz", Universidade de São Paulo. 
CASALE, W.L.; MINASSIAN, V.; MENGE, J.A.; LOVATT, C.J.; POND, E.; JOHNSON, E.; GUILLEMET, F. Urban and agricultural wastes for use as mulches on avocado and citrus and for delivery of microbial biocontrol agents. Journal of Horticultural Science, v. 70, n. 2, p. 315 - 352, 1995.

CHUNG, Y. R.; HOITINK, H. A. H.; LIPPS, P. E. Interactions between organic-matter decomposition level and soilborne disease severity. Agriculture, Ecosystems and Environment, v.24, p.183-193, 1988.

COSTA, J.L. da; MENGE, J.A.; CASALE, W.L. Investigations on some of the mechanisms by wich bioenhaced mulches can suppress Phytophthora root rot of avocado. Microbiological Research, v. 151, p. 183 - 192, 1996.

DE VLEESCHAUWER, D.; VERDONCK, O.; VAN ASSCHE, P. Phytotoxicity of refuse compost. BioCycle, v. 22, p. $44-46,1981$.

DOWNER, A.J.; MENGE, J.A.; POND, E. Effect of cellulolytic enzymes on Phyophthora cinnamomi. Phytopathology, v. 91, n. 9, p.839 - 846, 2001 a.

DOWNER, A.J.; MENGE, J.A.; POND, E. Association of cellulolytic enzyme activities in eucalyptus mulches with biological control of Phyophthora cinnamomi. Phytopathology, v. 91, n. 9, p.847-855, 2001 b.

ERWIN, D.C.; RIBEIRO, O.K. Phytophthora diseases worldwide. St. Paul: APS Press, 1996. 562p.

FANG, J.G.; TSAO, P.H. Efficacy of Penicillum funiculosum as a biological control agent against phytophthora root rots of azalea and citrus. Pyhtopathology, v.85, n. 8, p. $871-878,1995$.

FEICHTENBERGER, E. Doenças induzidas por fungos do gênero Phytophthora em citros e seu controle. Laranja, v.10, n.2, p.359-378, 1989. 
FEICHTENBERGER, E. Control of Phytophthora gummosis of citrus with systemic fungicides in Brazil. Bulletin OEPP, v.20, p.139-148, 1990.

FEICHTENBERGER, E.; MÜLlER, G. W.; GUIRADO, N. Doenças dos citros. In: KIMATI, H.; AMORIM, L.; BERGAMIN FILHO, A.; CAMARGO, L. E. A.; REZENDE, J. A. M. Manual de fitopatologia. São Paulo: Agronômica Ceres, 1997. v. 2, p. 261-296.

FERRIN, D. M.; KABASHIMA, J. N. In vitro insensitivity to metalaxyl of isolates of Phytophthora citricola and $P$. parasitica from ornamental hosts in southern California. Plant Disease, v.75, p.1041-1044, 1991.

FORTES NETO, P. Degradação de biossólidos incorporados ao solo avaliada através de medidas microbiológicas. Piracicaba, 2000. 113 p. Tese (Doutorado), Escola Superior de Agricultura "Luiz de Queiroz", Universidade de São Paulo.

GAMLIEL, A; AUSTERWEIL, M.; KRITZMAN, G. Non-chemical approach to soilborne pest management - organic amendments. Crop Protection, v.19, p.847 - 853, 2000.

GHINI, R.; MENDES, M.D.L.; BETTIOL, W. Método de hidrólise de diacetato de fluoresceina (FDA) como indicador de atividade microbiana no solo e supressividade a Rhizoctonia solani. Summa Phytopathologica, v.24, n.3/4, p.239-242, 1998.

GILLMAN, G.P.; BELL, L.C. Soil solution studies on weathered soils from tropical North Queensland. Australian Journal of Soil Research, v. 16, n. 1, p. 67 - 77, 1978.

GRIMM, G.R.; ALEXANDER, A.F. Citrus leaf pieces as traps for Phytophthora parasitica from soil slurries. Phytopathology, St. Paul, v.63, p. 540-541, 1973.

GRISI, B. M. Método químico de medição da respiração edáfica: alguns aspectos técnicos. Ciência e Cultura, v.30, n.1, p.82-88, 1978. 
HANDELSMAN, J.; RAFFEL, S.J.; MESTER, E.H.; WUNDERLICH, L.; GRAU, C.R. Biological control of damping-off alfalfa seedlings wiht Bacillus cereus UW85. Applied and Environmental Microbiology, v.56, n.3, p. 713 - 718, 1990.

HANDELSMAN, J.; NESMITH, W.C.; RAFFEL, S.J. Microassay for biological control of infection of tobacco by Phytophthora parasitica var. nicotianae. Current Microbiology, v.22 , p. 317-319, 1991.

HOITINK, H.A.J.; VAN DOREN, D.M.; SCHMITTHENNER, A.F. Suppression of Phytophthora cinnamomi in a composted hardwood bark potting medium. Phytopathology, v.67, n.4, p.561 - 565, 1977.

HOITINK, H.A.J.; BOEHM, M.J. Biocontrol within the context of soil microbial comunities: a substrate dependent phenomenon. Annual Review of Phytopathology, v. 37, p. 427 - 446, 1999.

KIM, K.D.; NEMEC, S.; MUSSON, G. Effects of composts and soil ammendments on soil microflora and Phytophthora root and crown rot of bell pepper. Crop Protection, v.16, n. 2, p. $165-172,1997$.

LAMBAIS, M.R.; de SOUZA, A.G. Impacto de biossólidos nas comunidades microbianas dos solos. In: BETTIOL, W.; CAMARGO, O. A. (Ed.) Impacto ambiental do uso agrícola do lodo de esgoto. Jaguariúna: Embrapa Meio Ambiente, 2000. cap. 17, p. 269 - 279.

LAPEÑA, I.; TUSET, J.J.; HINAREJOS, C.; MIRA, J.L. Interacción entre la conductividad eléctrica de la solucióndel suelo y la infección de Phytophthora citrophthora en plántulas de cinco portainjertos de cíticos. In: CONGRESO DE LA SOCIEDAD ESPAÑOLA DE FITOPATOLOGÍA, 10., Valencia, 2000. Resúmenes Valencia: SEF, 2000. p.218. 
LEWIS, J.A.; LUMSDEN, R.D.; MILLNER, P.D.; KEINATH, A.P. Suppression of damping-off of peas and cotton in the field with composted sewage sludge. Crop Protection, v.11, n.6, p.260-266, 1992.

LUMSDEN, R.D.; LEWIS, J.A.; MILLNER, P.D. Effect of composted sewage sludge on several soilborne pathogens and diseases. Phytopathology, v.73, n.11, p.15431548, 1983.

MAGALHÃES, A. F. J. Citros : nutrição e adubação. Cruz das Almas: Embrapa ,CNPMF, 1997. 37p. (Embrapa. CNPMF. Circular Técnica, 28).

MALAJCZUK, N. Microbial antagonism to Phytophthora. In: ERWIN, D.C.; BARTNICKI - GARCIA, S.; TSAO, P.H. (Ed.) Phytophthora: its biology, taxonomy, ecology and pathology. St. Paul: APS Press, 1983. cap. 16, p. $197-218$.

MARCHAL, J. Agrumes. In: MARTIN - PRÉVEL, P.; GAGNARD, J.; GAUTER, P. (Ed.). L' analyse végétale dans le contrôle de l' alimentation des plantes tempereés et tropicales. Paris: Technique et Documentation (Lavoisier), 1984. p. 361 - 398.

MATHERON, M.E.; MATEJKA, J.C. Effect of sodium tetrathiocarbonate, metalaxyl, and fosetyl-Al on development and control of Phytophthora root rot of citrus. Plant Disease, v. 75, n. 3, p. 264 - 268, 1991.

MATHERON, M.E.; MATEJKA, J.C. Effects of temperature on sporulation and growth of Phytophthora citrophthora and $P$. parasitica and development of foot and root rot on citrus. Plant Disease, v. 76, n. 11, p. 1103 - 1109, 1992.

MAY, L.M. Controle biológico, físico e químico de Phytophthora parasitica Dastur em mudas de citros. Piracicaba, 1994. 89 p. Dissertação (Mestrado); Escola Superior de Agricultura "Luiz de Queiroz”, Universidade de São Paulo. 
McGOVERN, R. J.; McSORLEY, R.; URS, R. R. Reduction of Phytophthora blight of Madagascar periwinkle in Florida by soil solarization in autumn. Plant Disease, v.84, n.2, p.185-191, 2000.

MELO, J.M.; MARQUES, M.O. Potencial do lodo de esgoto como fonte de nutrientes para as plantas. In: BETTIOL, W.; CAMARGO, O. A. (Ed.) Impacto ambiental do uso agrícola do lodo de esgoto. Jaguariúna: Embrapa Meio Ambiente, 2000. cap. 5, p. 109141.

MILLNER, P.D.; LUMDSEN, R.D.; LEWIS, J.A. Controlling plant disease with sludge compost. BioCycle, v. 22, p. $50-52,1981$

OLIVEIRA, F.C. Disposição de lodo de esgoto e composto de lixo urbano num latossolo vermelho - amarelo cultivado com cana - de - açúcar. Piracicaba, 2000. 247 p. Tese (Doutorado); Escola Superior de Agricultura "Luiz de Queiroz", Universidade de São Paulo.

PASCUAL, J.A.; HERNANDEZ, T.; GARCIA, C.; DE LEIJ, F.A.A.M.; LYNCH, J.M. Long-term suppression of Pythium ultimum in arid soil using fresh and composted municipal wastes. Biology and Fertility of Soils, v.30, p. 478-484, 2000.

PEREIRA, J.C.R.; ZAMBOLIM, L.; do VALE, F.X.R.; CHAVES, G.R. Compostos orgânicos no controle de doenças de plantas. Revisão Anual de Patologia de Plantas, v.4, p.353-379, 1996.

PLATT, R.G.; OPITZ, K.W. Propagation of citrus. In: REUTHER, W. (Ed.) The citrus industry. Berkeley: University of California, 1973. v.3. cap.1, p. $1-47$.

SCHOENMAKER, I. A. S.; GHINI, R. Fontes de matéria orgânica associadas à solarização do solo para o controle de Pythium spp. em crisântemo. Jaguariúna: Embrapa Meio Ambiente, 1999. 4p. (Embrapa Meio Ambiente. Pesquisa em Andamento,1). 
SCHOENMAKER, I. A. S. Solarização do solo associada à incorporação de matérias orgânicas para o controle de Pythium spp Piracicaba, 2000. 50 p. Dissertação (Mestrado); Escola Superior de Agricultura "Luiz de Queiroz", Universidade de São Paulo.

SMITH, V.L.; WILCOX, W.F.; HARMAN, G.E. Potential for biological control of Phytophthora root and crown rots of apple by Trichoderma and Gliocladium spp. Phytopathology, v.80, n.9, p. $880-885,1990$.

TIMMER, L. W.; GRAHAM, J. H.; ZITKO, S. E. Metalaxyl-resistant isolates of Phytophthora parasitica: occurrence, sensitivity, and competitive parasitic ability on citrus. Plant Disease, v.82, p.254-261, 1998.

TOMOYUKI, M.T. Alternativas de disposição final de biossólidos gerados em estações de tratamento de esgotos. In: BETTIOL, W.; CAMARGO, O. A. (Ed.) Impacto ambiental do uso agrícola do lodo de esgoto. Jaguariúna: Embrapa Meio Ambiente, 2000. cap. 4, p. 69 - 105.

WIDMER, T. L.; GRAHAM, J. H.; MITCHELL, D. J. Composted municipal waste reduces infection of citrus seedlings by Phytophthora parasitica. Plant Disease, v.82, n.6, p.683-688, 1998.

WILCOX, W.F.; PRITTS, M.P.; KELLY, M.J. Integrated control of Phytophthora root rot of red raspberry. Plant Disease, v.83, n. 12, p. 1149 - 1154, 1999.

WORKNEH, F.; VAN BRUGGEN, A.H.C.; DRINKWATER, L.E.; SHENNAN, C. Variables associates with corky root and Phytophthora root rot of tomatoes in organic and conventional farms. Phytopathology, v. 83, n.5, p.581-589, 1993.

YOU, M.P.; SIVASITHAMPARAM, K.; KURTBÖKE. Actinomycetes in organic mulch used in avocado plantations and their ability to supress Phytophthora cinnamomi. Biology and Fertility of Soils, v. 22, p. $237-242,1996$. 